Seafood globalization: implications for vulnerability and resilience

\author{
Jessica Ann Gephart \\ Findlay, Ohio
}

B.A., Miami University, 2011

A Dissertation presented to the Graduate Faculty of the University of Virginia in Candidacy for the Degree of Doctor of Philosophy

Department of Environmental Sciences

\author{
University of Virginia
}

May, 2016 


\section{AbSTRACT}

Seafood is among the most highly traded food commodities and plays an important role in global nutrition. Further, its production is closely tied to the ecosystems that support harvests and the natural resources (e.g. clean water) that allow aquaculture. Together intensive trade and tight linkages between seafood production and the environment distances consumers from the environmental impacts of seafood production and exposes seafood production to environmental change and variability. The goal of this dissertation is to assess the globalization of seafood and the resulting implications for vulnerability and resilience.

The historical structure and evolution of the seafood trade network was characterized using network analysis. This analysis revealed an increase in trade partnerships by $65 \%$ and an increase in traded quantity by $58 \%$ over the period 1994 to 2012 . Additionally, the trade patterns in the network indicate: increased influence of Thailand and China, strengthened intraregional trade, and increased exports from South America and Asia.

This increasing globalization can allow countries to buffer against local or regional shocks that might cause sharp declines in seafood supply but also exposes nations to external shocks transmitted through the trade network. Central and West Africa were found to be the most vulnerable to such shocks in a forward shock-propagation model. Historical cases of shocks to seafood production are identified using a statistical shock identification approach with a complementary qualitative approach. The identified cases indicate that there is no trend in the frequency or magnitude of shocks in the aggregated production or in the magnitude of shocks in the species production, but there is an increase in the frequency of shocks in the species time series. Further, the highest number of shocks occurred in Europe, Africa, and Asia, which also tended to 
have shocks of larger magnitude. Shock rates and magnitudes were similar among species groups, but shocks occurred more frequently in aquaculture systems than capture systems.

In addition to adapting to changes in domestic seafood production through trade, countries can alter production of other food sources in the long run. This ability is assessed by comparing the water cost for countries to replace marine protein with terrestrial foods using available water resources. Replacing marine with terrestrial protein would require an additional $350 \mathrm{~km}^{3} \mathrm{y}^{-1}$ of water globally. This quantity can alternatively be viewed as a current water savings of $4.6 \%$. The importance of these freshwater savings is highly uneven around the globe, with savings ranging from as little as 0 to as much as $50 \%$. For countries with a high use of marine protein and limited water resources, seafood is an important component of joint food-water security.

Seafood trade has increased globally in recent decades. This dissertation quantifies the network structure and degree of globalization for seafood. This globalization provides both opportunities and risks in terms of the vulnerability and resilience of the food system. Within this context of increasing globalization, this dissertation presents three new perspectives on the vulnerability and resilience of the global seafood system through modeled exposure to shocks in the network, historical impacts of shocks on trade and seafood supply, and the ability of countries to replace marine foods with available resources. 


\section{ACKNOWLEDGEMENTS}

I would first like to thank Dr. Michael Pace for advising me on this dissertation. He has been an invaluable mentor, supported my growth as a scientist, and helped me foster new collaborations to pursue this interdisciplinary research topic. This dissertation greatly benefitted from the diverse perspectives of my collaborators Max Troell and Lisa Deutsch at the Stockholm Resilience Center (SRC), and Elena Rovenskaya, Ulf Dieckmann, and Åke Brännström at the International Institute for Applied Systems Analysis (IIASA). I would also like to thank my committee members, Drs. Paolo D'Odorico and Hank Shugart, for their contributions and advice on this dissertation and Dr. Mark White for serving as the Dean's Representative.

Additionally, I have benefitted from a number of colleagues, friends, and family members who provided advice, proofread papers, and supported me along the way. Specifically, I would like to thank David Seekell, Grace Wilkinson, Kyle Emery, Alice Besterman, Cal Buelo, Joel Carr, Michael Saha, Stephen Kostyo, and my siblings and parents, along with the other Environmental Science graduate students, colleagues at the SRC, and the members of the IIASA Evolution and Ecology group and 2014 Young Scientists Summer Program (YSSP).

The research within this dissertation was funded and supported by the National Science Foundation (NSF) Graduate Research Fellowship, IIASA YSSP, the NSF Graduate Research Opportunities Worldwide Program, and the University of Virginia Department of Environmental Sciences. I would also like to recognize the United Nations, the Food and Agriculture Organization, and the Water Footprint Network for maintaining, documenting, and making the data used in my research publically available. 


\section{TABLE OF CONTENTS}

Abstract......................................................................2

Acknowledgements.....................................................4

Table of Contents.........................................................

List of figures and tables..............................................6

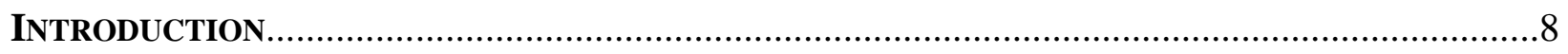

Chapter 1: $\quad$ Structure and evolution of the global seafood trade network...................13

CHAPTER 2: $\quad$ Vulnerability to shocks in the global seafood trade network....................41

CHAPTER 3: $\quad$ Patterns of shocks to global fish production and trade............................67

CHAPTER 4: $\quad$ Freshwater savings from marine protein consumption............................96

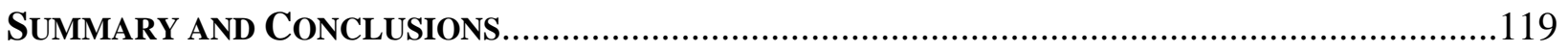

Appendix 1: Chapter 1 Supplementary Material.................124

Appendix 2: Chapter 2 Supplementary Material.................135

Appendix 3: Chapter 3 Supplementary Material..................145 


\section{LIST OF FIGURES}

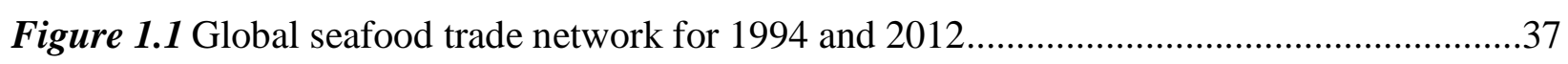

Figure 1.2 Example changes in trade for three countries......................................................38

Figure 1.3 Total trade, degree, and clustering coefficient time series...................................39

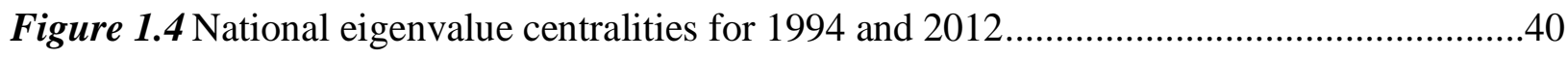

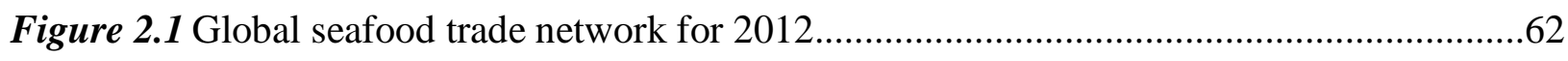

Figure 2.2 Exposure versus gross imports and number of trade partners...............................63

Figure 2.3 Regional shock exposure for shocks initiated in each region.................................64

Figure 2.4 Influence of GDP parameter on shock distribution..........................................65

Figure 2.5 Regional shock exposure versus sensitivity....................................................66

Figure 3.1 Method steps to identify shocks in time series..................................................90

Figure 3.2 Total production shock magnitude and cause time series....................................91

Figure 3.3 Regional shock rate, magnitude, and recovery ...................................................92

Figure 3.4 Species production shock magnitude and frequency time series...........................93

Figure 3.5 Species shock rate, magnitude, and recovery .....................................................94

Figure 3.6 Case study time series of production, imports, exports, and supply.......................95

Figure 4.1 Water savings and scarcity map................................................................115

Figure 4.2 Available land and water resources compared to water savings...........................116

Figure 4.3 Top national per capita water savings........................................................117

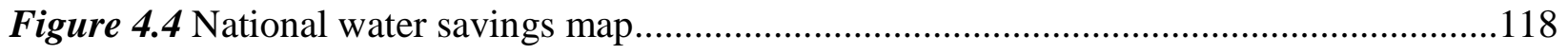




\section{LIST OF TABLES}

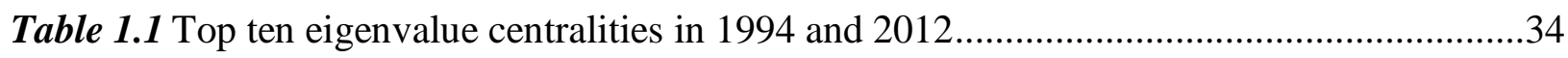

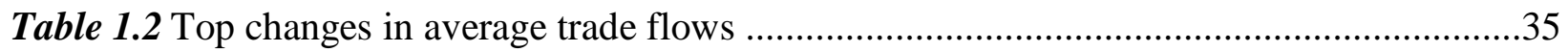

Table 3.1 Possible reasons for increases or decreases in shocks...........................................8

Table 3.2 Changes in imports, exports, and supply at shock points........................................89

Table 4.1 Water footprints and protein consumption levels by food product...........................113

Table 4.2 Example water savings calculations for five countries.........................................114 


\section{INTRODUCTION}

The food production system directly links humans and the environment. The food system consists of food production, processing, distribution, consumption, and waste management (Pothukuchi and Kaufman 2000). This system interacts with the environment in two directions: food production alters the environment through resource use and extraction, and the environment impacts the food system through climate variability and natural disasters.

Global food production has increased to keep up with population growth and changing diet preferences. Food production and its expansion contributes to increases in greenhouse gas emissions, nutrient pollution, water use, and land use (Gephart et al. 2016a). Currently, 15\% of anthropogenic greenhouse gas emissions is related to food production (Olivier et al. 2005). While fertilizer application has improved yields, nutrients are released into waterways, groundwater, and the atmosphere, leading to water acidification, eutrophication, climate change, and biodiversity loss (Galloway et al. 2003; Erisman et al. 2013). Further, over $80 \%$ of freshwater use is allocated to food production and land conversion to crops further increases biodiversity loss, nutrient runoff, and soil erosion (Carr et al. 2013; Turner et al. 2007; Lambin and Meyfroidt 2011).

Conversely, the environment can also disrupt the food production system and disruptions at any stage of the food system can limit access to food. Reliable crop production requires temperatures and precipitation within specific ranges. Consequently, heat waves, floods, and droughts can all interrupt crop production. Additionally, El Niño events famously reduce catch in some fisheries. Other natural disasters, such as hurricanes and earthquakes, can interrupt food production at numerous points in the system. The exposure of food systems and ability to adapt to such disruptions contributes to the food system's overall vulnerability and resilience. 
Any particular local food system's vulnerability and resilience must be considered within the context of an increasingly globalized food system. Currently about one fourth of the world's food production is internationally traded and this proportion continues to grow (D'Odorico et al. 2014). While trade can allow countries to overcome local or regional losses to their food supply, reliance on international food trade also exposes countries to risks from external perturbations. Countries that are nutritionally or economically dependent on international trade of a commodity may be adversely affected by such shocks.

The goal of this dissertation is to assess the globalization of seafood and the resulting implications for vulnerability and resilience. Seafood was selected because it is underrepresented in the global food trade literature, a highly traded commodity, exposed to multiple potential shocks, and an important source of nutrition globally. This dissertation quantifies the degree of globalization in the trade network, identifies regions most vulnerable to shocks in the seafood trade network, compares trends and regional patterns in the occurrence of shocks to seafood production, and assesses the ability of nations to replace seafood with terrestrial products based on available water resources. In each case seafood losses and trade are connected to national food security based on changes in seafood supply and protein contribution.

The potential food security and environmental implications of seafood globalization cannot be evaluated without first describing the system and its recent changes. Chapter 1 characterizes the structure and evolution of the global seafood trade using network analysis, including metrics quantifying the globalization of seafood, shifts in bilateral trade flows, changes in centrality and comparisons of seafood to agricultural and industrial trade networks. From 1994 to 2012 the number of countries trading in the network remained relatively constant, while the number of trade partnerships increased by over $65 \%$. Over this same period, the total quantity of seafood traded 
increased by $58 \%$ and value increased $85 \%$ in real terms. These changes signify the increasing globalization of seafood products. Additionally, the trade patterns in the network indicate: increased influence of Thailand and China, strengthened intraregional trade, and increased exports from South America and Asia. This chapter was published in Environmental Research Letters (Gephart and Pace 2015).

The increasing globalization of seafood trade can allow countries to buffer against local or regional shocks but also exposes nations to external shocks transmitted through the trade network. Chapter 2 presents a forward shock-propagation model using the global seafood trade network to quantify exposure to shocks under a range of shock scenarios. Food-security outcomes are then assessed by comparing changes in national fish supplies to indices of each country's nutritional fish dependency. The results indicate that Central and West Africa are the most vulnerable to shocks, with their vulnerability increasing when a willingness-to-pay proxy is included. This chapter was published in Environmental Research Letters (Gephart et al. 2016) with Elena Rovenskaya, Ulf Dieckmann, Michael Pace, and Åke Brännström.

Chapter 3 uses a statistical shock identification approach with a complementary qualitative approach to identify shocks in fisheries catch time series. Based on the set of identified shocks, this chapter finds no trend in the frequency and magnitude of shocks, compares patterns in shocks among regions and production systems, and evaluates how shocks alter the trade balance and domestic supply. Since the impact of a particular shock is context dependent, this chapter also describes four case studies of shocks. Through the analysis of patterns in historical shocks, this chapter aims to identify potential vulnerabilities in the seafood production system. Further, evaluating the impact of shocks informs whether and when a regional shock will have more distant 
impacts through international trade, while evaluating the impact of shocks on seafood supply informs whether and when shocks may impact local nutrient availability.

In addition to adapting to changes in domestic seafood production through trade, countries can alter production of other food sources in the long run. Chapter 4 evaluates the water cost and ability of countries to replace marine protein with terrestrial foods based on current consumption patterns and water resources. Replacing marine with terrestrial protein would require an additional $350 \mathrm{~km}^{3} \mathrm{y}^{-1}$ of water. This can alternatively be viewed as a current water savings of $4.6 \%$. The importance of these freshwater savings is highly uneven around the globe, with savings ranging from as little as 0 to as much as $50 \%$. Of the 25 countries with the highest water savings from marine protein consumption, 8 are already experiencing some form of water stress. This indicates that marine protein is an important component of their joint food-water security. This chapter was published in Environmental Research Letters (Gephart et al. 2014) with Michael Pace and Paolo D'Odorico.

Seafood trade has increased globally in recent decades. Prior to this dissertation the network structure and degree of globalization were unquantified for seafood. This globalization provides both opportunities and risks in terms of the vulnerability and resilience of the system. Within the context of increasing globalization, this dissertation presents three new perspectives on the vulnerability and resilience of the global seafood system through modelled exposure to shocks in the network, historical impacts of shocks on trade and seafood supply, and the ability of countries to replace marine foods with available resources. 


\section{References}

Carr, JA, P D'Odorico, F Laio and L Ridolfi (2013) Recent history and geography of virtual water trade. PLoS ONE, 8(2): e55825, doi: 10.1371/journal.pone.0055825.

D'Odorico, P, J Carr, L Francesco, L Ridolfi, and S Vandoni (2014) Feeding humanity through global food trade. Earth's Future, 2(9): 458-469.

Erisman, JW, JN Galloway, S Seitzinger, A Bleeker, NB Dise, R Petrescu, AM Leach and W de Vries (2013) Consequences of human modification of the global nitrogen cycle. Philosophical Transactions of the Royal Society, 368(1621), doi: 10.1098/rstb.2013.0116

Galloway, JN, JD Aber, JW Erisman, SP Seitzinger, RW Howarth, EB Cowling and BJ Cosby (2003) The nitrogen cascade. BioScience, 53: 341-356.

Gephart, JA, KF Davis, K Emery, A Leach, JN Galloway and ML Pace (2016) The environmental cost of subsistence: Optimizing diets to minimize footprints. Science of the Total Environment, 553: 120-127.

Gephart, JA and ML Pace (2015) Structure and evolution of the global seafood trade network. Environmental Research Letters, 10(12): 125014.

Gephart, JA, ML Pace and P D'Odorico (2014) Freshwater savings from marine protein consumption. Environmental Research Letters, 9: 014005.

Gephart, JA, E Rovenskaya, U Dieckmann, ML Pace and Å Brännström (2016) Vulnerability to shocks in the global seafood trade network. Environmental Research Letters, 11(3): 035008 .

Lambin EF and P Meyfroidt (2011) Global land use change, economic globalization, and the looming land scarcity. Proceedings of the National Academy of Sciences, 108: 3465-3472.

Olivier JGJ, JA Van Aardenne, FJ Dentener, V Pagliari, LN Ganzeveld and JAHW Peters (2005) Recent trends in global greenhouse gas emissions: regional trends 1970-2000 and spatial distribution of key sources in 2000. Environmental Sciences, 2(2-3): 81-99.

Pothukuchi, K and JL Kaufman (2000) The food system. Journal of the American Planning Association, 66(2): 113-124. 
Turner BL, EF Lambin and A Reenberg (2007) The emergence of land change science for global environmental change and sustainability. Proceedings of the National Academy of Sciences, 104: 20666-20671. 


\title{
CHAPTER 1: STRUCTURE AND EVOLUTION OF THE GLOBAL SEAFOOD TRADE NETWORK ${ }^{1}$
}

\begin{abstract}
The food production system is increasingly global and seafood is among the most highly traded commodities. Global trade can improve food security by providing access to a greater variety of foods, increasing wealth, buffering against local supply shocks, and benefit the environment by increasing overall use efficiency for some resources. However, global trade can also expose countries to external supply shocks and degrade the environment by increasing resource demand and loosening feedbacks between consumers and the impacts of food production. As a result, changes in global food trade can have important implications for both food security and the environmental impacts of production. Measurements of globalization and the environmental impacts of food production require data on both total trade and the origin and destination of traded goods (the network structure). While the global trade network of agricultural and livestock products has previously been studied, seafood products have been excluded. This study describes the structure and evolution of the global seafood trade network, including metrics quantifying the globalization of seafood, shifts in bilateral trade flows, changes in centrality and comparisons of seafood to agricultural and industrial trade networks. From 1994 to 2012 the number of countries trading in the network remained relatively constant, while the number of trade partnerships increased by over $65 \%$. Over this same period, the total quantity of seafood traded increased by $58 \%$ and the value increased $85 \%$ in real terms. These changes signify the increasing
\end{abstract}

\footnotetext{
${ }^{1}$ Gephart, JA and ML Pace (2015) Structure and evolution of the global seafood trade network. Environmental Research Letters, 10(12): 125014.
} 
globalization of seafood products. Additionally, the trade patterns in the network indicate: increased influence of Thailand and China, strengthened intraregional trade, and increased exports from South America and Asia. In addition to characterizing these network changes, this study identifies data needs in order to connect seafood trade with environmental impacts and food security outcomes.

\section{Introduction}

As the source of almost $20 \%$ of animal protein consumed by humans (FAO 2014) as well as essential fatty acids and micronutrients, fish and other aquatic food (hereafter, seafood) play an important role in global food security. This is especially true for many coastal and developing nations (Gephart et al. 2014). In order to keep up with the growing human population, increasing per capita seafood consumption and stagnating global catch, aquaculture production has rapidly expanded (FAO 2014). The resulting diversity of production methods and species produced yields a wide range of environmental impacts of seafood production.

Further, seafood is one of the most highly traded commodities, making up about $10 \%$ of all food trade (by value) and exceeding the value of sugar, maize, coffee, rice, and cocoa trade combined (Asche et al. 2015). Nearly $40 \%$ of seafood production (by volume) is internationally traded and this percent has been increasing in recent decades (FAO 2014). The business of seafood trade has also evolved during the recent period of growth in global seafood trade. The high level of international trade exposes the vast majority of seafood to trade competition and causes international seafood prices to impact domestic, non-internationally traded seafood prices (Tveterås et al. 2012). Large transnational companies have emerged and increased the consolidation and vertical integration of the seafood industry (Österblom et al. 2015). Increased international trade of seafood has facilitated the substitution of fish from new stocks, including 
new species, when a given stock declines. For example, when the North Sea cod stock was in decline, cod was imported from other regions and substituted with other whitefish (Crona et al. 2015). These recent decades of rapid growth and industry change in production make seafood trade a particularly important study system.

However, despite the nutritional importance of seafood and the high level of international trade, seafood has been excluded from previous studies on global food trade networks. The frequently used food trade database, the Food and Agriculture Organization's FAOSTAT trade matrix, does not contain seafood trade data (FAOSTAT 2014). As a result, studies using this database do not consider seafood (e.g. Konar et al. 2011; Dalin et al. 2012; Carr et al. 2013). Previous studies have shown an increase in seafood trade globally, increases in total imports or exports from specific countries (FAO 2014), the role of seafood trade in food security of developed and developing countries (Asche et al. 2014), and a net movement of seafood from the global south to the global north (Smith et al. 2010, Asche et al. 2014). While these studies have provided important insights into global seafood trade, they cannot extract the trade network or identify changes in trade flow patterns within the network. The network structure indicates the degree of globalization, identifies influential trade partners, and connects consumers to the environmental impacts of food production.

Globalization provides both benefits and risks for food security and the environmental impacts of food production (D'Odorico et al. 2014). International trade can improve food security by providing access to a greater variety of foods, buffering against local supply shocks, and providing surplus value through the export of high-value species. For example, seafood exports from developing countries can improve food security through economic stimulation and employment at the national level (Jaunky 2011), but the impact of fish trade for the most food 
insecure people is difficult to measure (McClanahan et al. 2015). International trade may also lessen environmental impacts by increasing overall use efficiency for some resources (e.g. Yang et al. 2006) or through the "environmental Kuznets curve" where trade stimulates economic growth that allows wealthier populations to afford more environmental protections (Verburg et al. 2009).

However, international trade by definition involves more than one country and distances producers from consumers. As a result, countries may become dependent on foods from foreign nations, which can be problematic if a government enacts a policy that limits exports. Both theoretical and case study research suggests that increased reliance on international trade exposes nations to external supply shocks (Puma et al. 2015). Negative environmental impacts can also arise through international trade from the limited feedbacks between consumers and the ecological impacts of their food production (Crona et al. 2015). Trade allows depleted resources to be exploited in new geographical areas leading to the possibility of serially-depleted stocks. This is a particularly high risk when regulations are insufficient. Thus, improved management may not reduce global fishing pressure, but instead shift the fishing pressure to areas with fewer fishing regulations (Worm and Branch 2012). For example when spiny dogfish trade from the United States decreased as a result of the implementation of a fishery management plan, there was an increase in exports from Canada, and new areas of exploitation developed in Africa, Asia, and South America (Dell'Apa et al. 2013). More generally stock depletion in the northern hemisphere has led to an increased pressure on tropical fisheries and has contributed to a net flow of seafood from developing to developed countries (McClanahan et al. 2015).

These potential benefits and risks for food security, the environment, and resource management arising from global seafood trade cannot be evaluated without first characterizing the 
trade flows within the network. This study quantifies the structural changes that occurred in the global bilateral seafood trade network in terms of both value and quantity (tonnes). Following previous studies on structural changes in virtual water trade (e.g. Konar et al. 2011; Dalin et al. 2012; Carr et al. 2013), we apply network methods to characterize the evolution of global seafood trade, provide metrics of the globalization of seafood, quantify shifts in bilateral trade flows, identify changes in the most central players, and compare the seafood trade network to agricultural and industrial trade networks. Based on the findings with this data, we also identify future data needs in order to connect seafood trade with more specific environmental impacts and food security outcomes.

\section{Methods}

The global seafood trade network was constructed for each year from 1994 to 2012 using data from the United Nations Comtrade database. The network structures were quantified based on the network average degrees, degree distributions, clustering coefficients, and eigenvector centralities (see below). The changes in trade flows were then evaluated and compared across trade relationships. Similar methods have previously been used to study patterns and changes in trade as, for example, study of the topological properties of the World Trade Web (Fagiolo et al. 2010; Garlaschelli and Loffredo 2005), food trade within the United States (including seafood) (Lin et al. 2014), and study of the structure and evolution of the global virtual water trade network (Konar et al. 2011; Dalin et al. 2012). Additionally, a series of papers used network analysis with virtual water trade data to look at the temporal variability (Carr et al. 2012a), trade dependence (Suweis et al. 2012), network inequalities (Carr et al. 2012b and Carr et al. 2015), and network community structure (D'Odorico et al. 2012). While these virtual water studies effectively investigate agriculture and livestock commodity trade, they do not consider seafood trade. 


\section{Data description}

We used the United Nation's Comtrade database for this analysis because it contains bilateral trade information (i.e. data on trade from country A to country B, etc.). This differs from the more commonly used FAO FishStat database, which contains only total imports and total exports (i.e. no information on from where the trade originates). Both databases contain data on imports and exports in US dollars. Comtrade does not contain data on quantity trade flows for all seafood trade, but we converted the dollar flows to metric tonnes using average tonne/USD factors for each country's imports based on FishStat data. The networks are constructed from both reported imports and exports in the Comtrade database, with the maximum value reported by the importer or exporter used. The network analysis is then conducted on both quantity and value data. The network for this analysis represents seafood products destined for human consumption (selected from Harmonized System codes 03 and 16) for 1994 to 2012. To compare the two databases (Comtrade and FishStat), we sum across each country's imports and exports in the Comtrade data and ran a linear regression through the origin against the FishStat total import and export data. We find that both the total imports and total exports from the Comtrade data explain a large proportion of the variability in the FishStat data (Appendix 1, Supplementary Figure 1-2 and Supplementary Table 1). The slopes near one indicates that the Comtrade data agree well with the FAO's estimates for both value and quantity across years.

About half of the imports globally are reported from "World," which does not specify import origins and were therefore excluded from the analysis. The percent of trade to each region from "World" remained relatively constant for each year (Appendix 1, Supplementary Figure 3). In order to test whether reporting to "World" biased our assessment of the trade network, we compared the fit of the Comtrade total exports versus FishStat total exports when each country's 
"World" imports are distributed proportionately to the known trade network versus distributed according to proportions ( 0 to 1$)$ drawn from a Dirichlet distribution. The fit of the "World" trade distributed proportionately to the known trade network fell in the upper tail of the distribution of fits, with 0.9999994 of the distribution's density falling below it. This suggests that the reporting to "World" is unbiased and that little structural information is masked by "World." As a result, removing this node decreases the total imports, but does not affect structural features of the network. See the Supporting Information for more details about the analysis of the "World" node. Trade data were adjusted for inflation using the United States consumer price index from the World Bank using 2010 as the baseline (World Bank 2015).

Additionally, countries which no longer exist were combined with the modern recognized nation following Carr et al. (2013). The resulting dataset contains 205 nodes and includes territories with Comtrade (2010) country codes that operate and report trade independently, but are not independent states (e.g. Hong Kong). Nodes are occasionally referred to as countries in this paper, but actually represent both countries and territories. It is important to also note that this trade data provides information on the countries engaging in trade, but this does not necessarily represent the geographical origin of the seafood products.

\section{Data analysis}

Node degree measures how many trade partners each country has, while the degree distribution shows whether the network has a few countries with many trade partners and many countries with few trade partners or vice versa. Degree distributions are commonly used to describe the structure of large networks that cannot easily be depicted. Degree distributions are based on the unweighted, directed in-degrees $\left(\mathrm{k}_{\mathrm{i}}^{\mathrm{in}}\right)$ and out-degrees $\left(\mathrm{k}_{\mathrm{j}}^{\text {out }}\right)$ and calculated for the network 
using the adjacency matrix, $A_{i j}$, where $i$ represents the row and $j$ represents the column. For $n$ countries in the network, $\mathrm{k}_{\mathrm{i}}^{\mathrm{in}}=\sum_{\mathrm{j}=1}^{\mathrm{n}} \mathrm{A}_{\mathrm{ij}}$ and $\mathrm{k}_{\mathrm{j}}^{\text {out }}=\sum_{\mathrm{i}=1}^{\mathrm{n}} \mathrm{A}_{\mathrm{ij}}$. Note that the average in-degree equals the average out-degree across a network (Newman 2010).

The clustering coefficient, or network transitivity, is the probability that the adjacent edges of a node are connected, and is equal to six times the number of triangles (a loop of length three) divided by the number of paths of length two (Newman 2010). Clustering was calculated using the igraph package function "transitivity" in R programming language (Csardi and Nepusz 2006).

Eigenvector centrality was chosen as the measure of centrality in the network because it evaluates both the number of connections (neighbors) a node has, as well as the connectedness of the neighbors. The eigenvector centrality for the undirected weighted trade network was calculated using the igraph package "evcent" function (Csardi and Nepusz 2006). All analyses were conducted using R statistical software (R Core Team 2011). Because of the large number of countries (nodes) in the network, we aggregated results by region for presentation. Country groupings into regions are depicted in Figure 1.1. This circlular data figure was generated by Circos software (Krzywinski et al. 2009) and is similar to trade and flow figures produced by others (e.g. Dalin et al. 2012).

\section{Results}

The global seafood trade network grew rapidly from 1994 to 2012 in terms of the number of trading partners and the total trade flows. Thailand, the United States, and Chile exemplify some of the changes observed in the network structure (Figure 1.2 and Appendix 1, Supplementary Figure 4). Thailand experienced dramatic growth in the value of exports and in the number of countries to which it exports. In contrast, the United States increased the value of its imports by 
over $60 \%$, with little change in the number of countries from which it imports. Chile had relatively few import or export partners at the start of the study period (1994). By 2012, the number of export partners grew and the export value more than tripled.

Across the entire network, the number of countries and territories (nodes) actively trading in the network remained relatively constant (194 in 1994 and 197 in 2012), while the number of trade partnerships (edges) increased by 65\% (3988 in 1994 and 7141 in 2012). Further, each node had an average of 25.3 connections in 1994 and an average of 41.7 in 2012 (Figure 1.3). Thus, the trade network became increasingly connected over time. The countries with the largest increases in number of export partners (difference between 2008-2012 average and 1994-1999 average) were South Africa (100.8), Vietnam (100.6, China (80.4), Namibia (76.6), and Indonesia (73.2), while the largest increase in number of import partners were South Africa (83.2), Vietnam (60), United Arab Emirates (48.4), and Nigeria (46.4). Few decreases in degree occurred. Of the 205 countries and territories, $86 \%$ increased or saw no change in the number of export partners and $88 \%$ increased or saw no change in the number of import partners. The decreases in degree that did occur were of much smaller magnitude than the increases. The largest decreases in the number of export partners are Venezuela (-14), Saint Vincent and the Grenadines (-7.6), and the Cayman Islands (-5.8), while the largest decreases in the number of import partners are Guadeloupe (-20.6), Martinique (-20.4), and Réunion (-12.8).

The network consists of many countries with few trade links (low degree), and few countries with many trade links (high degree). However, in more recent years the degree distribution has shifted so that there were more countries with more trade links (higher degree, Appendix 1, Supplementary Figure 5). The clustering coefficient for the network also increased from 0.46 to 0.58 , indicating the network has become more transitive in trade links (Figure 1.3). 
This means countries increasingly tend to trade with countries that also trade with one another, forming more frequent triangles within the network (Fagiolo et al. 2010). The network was dominated by short-lived trade relationships. Over the time period considered, there were nearly 5000 edges lasting a single year, around 3000 permanent edges, and fewer than 1000 edges lasting intermediate lengths (Appendix 1, Supplementary Figure 6).

In 1994 the most central countries in the network (measured by eigenvalue centrality) were several Western and Northern European countries, the United States, Japan, and Thailand (Table 1.1). By 2012 Thailand and China became the top two most central countries in the network (Table 1.1). Over the entire network, most countries became more central, with most countries lying above the one to one line in Figure 1.4. This effect is strongest for nations with the lowest centrality scores in 1994 (from 0.0-0.2), as represented by the distance from the one to one line.

At a regional level (countries grouped into 18 regions; see Figure 1.1), the network was already highly connected in 1994, with trade links occurring in $90 \%$ of the possible edges. The network still became more highly connected by 2012, with trade links existing in $98 \%$ of the possible edges. The main changes increasing the connectivity were the 9 new export partners for Central America, 4 new export partners each for Eastern Europe, and Southern and Central Africa, along with the 10 new import partners for West Africa and 7 new import partners for Central Africa (Figure 1.1). The largest increases in value trade flows from 1994-2012 occurred within Northern Europe, from Southeast and Eastern Asia to North America, within Western Europe, within Southern Europe, and from Northern Europe to Central-Western Asia. The largest decreases occurred from North America to Eastern Asia, and from Southeast and South-Central Asia to Eastern Asia. 
In terms of value, the largest trade flow increase was nearly three times the largest decrease. Changes in trade flows for individual countries represent the difference of the average trade flows for 2008-2012 and 1994-1999. Of total possible trade links among the 205 nodes in the network, $25 \%$ increased and $9 \%$ decreased (no change in the remaining edges, which were zero initially and remained zero), with the increases being much larger than the decreases. The largest increases in trade flows in terms of quantity occurred from the Russian Federation, the United States and Norway to China, from China to the Republic of Korea, and from Norway to Sweden (Table 1.2). The largest decreases are from the United States, Indonesia, the Republic of Korea, Canada and India to Japan (Table 1.2). In terms of value, the largest increases in trade flows were from Norway to Sweden, from China, Vietnam, Indonesia, Canada, Thailand and Chile to the United States, and from the Russian Federation and the United States to China (Table 1.2).

\section{Discussion}

This study provides the first description of the global seafood trade network, including its structural evolution from 1994 to 2012. During this period the network became more connected, with a $65 \%$ increase in the average number of trade partnerships (node degree). The increase in average degree occurred largely through a shift in the degree distribution resulting in more countries with high degrees in the network (Appendix 1, Supplementary Figure 5). The trade relationships between countries tended to be short-lived, with a domination of trade links lasting

only a single year (Appendix 1, Supplementary Figure 6). The trade flows in the reported network increased from $\$ 71.2$ billion and 17.8 million tonnes in 1994 to $\$ 131.6$ billion (in 2010 US dollars) and 28.1 million tonnes in 2012, representing 58.2\% growth in quantity $84.9 \%$ real growth in value (Figure 1.3). This gives a real growth rate of $4.5 \%$ per year (Figure 1.3). This rate of increase in total trade value agrees with the rate of increase in trade of all seafood products reported by the 
FAO, including their estimate of $4.1 \%$ real growth per year (FAO 2014). This period of real growth in terms of value corresponds to a period of decreasing average traded seafood prices in real terms (FAO 2014). The trade price of aquaculture has decreased at a faster rate due to lower production costs improved production technologies, and lower distribution costs (FAO 2014; Asche and Smith 2009). As a result, expanding aquaculture production has contributed to the decreasing overall traded seafood price. However, in the last few years production costs have increased and demand has remained high, causing trade prices to begin rising (FAO 2014). Higher prices for capture species has been attributed to higher energy costs for fishing vessels and increasing scarcity of capture fishery resources (FAO 2014; Tveterås et al. 2012).

In addition to the growth in trade across the entire trade network, there were substantial shifts in the trade flows, with the largest increases in net imports in North America, Southern Europe, and Western Europe, and the largest decreases in net imports in Southeast Asia, South America, and Northern Europe (Figure 1.1). A notable difference between the regional trade networks in terms of value versus quantity is that West Africa increased the tonnes of imports to a much greater degree than it increased the value of its imports, with large increases in imports from Northern Europe and Eastern Asia (Figure 1.1). This indicates that West Africa is importing lowvalue seafood from these regions. These changes in trade patterns in Figure 1.1 can only be derived from a network analysis.

The average node degree of 30 for 2012 is lower than the average node degree for the trade network of all commodities ( 90 in 2000) (Fagiolo et al. 2010) and the agricultural product (represented by virtual water) trade network (>70 in 2008) (Carr et al. 2012a). From 1994 to 2012 the average node degree for the seafood trade network increased by $65 \%$, which is similar to the rate of increase in average node degree from 1986 to 2008 for the virtual water trade network (Carr 
et al. 2012a). This result suggests that the rate of increase in trade partnerships is similar for both terrestrial and aquatic foods. Additionally, the increase in average node degree for food commodities differs from the relatively constant average node degree observed in the overall trade network from 1981 to 2000 (Fagiolo et al. 2010). This means that food products are currently in a period of greater increasing globalization in terms of connectivity relative to other traded products. These two metrics of the increasingly globalized seafood system add to a recent study that found an increasing distance between seafood consumers and their seafood production (Watson et al. 2015b).

While the increasing average degree and clustering coefficient indicate greater connectivity and transitivity in the overall network, an analysis of the trade flows reveals that the largest trade increases occur between countries in the same region, represented as arcs to the same region in Figure 1.1 (and confirmed in the trade data matrices). This increasing regionalization of trade has been observed in other trade networks and has been attributed to the formation of regional free trade agreements (Iapadre and Tajoli 2014). However, this trend may weaken as new preferential trade agreements are now also being formed between geographically distant countries (Iapadre and Tajoli 2014).

In the future, further changes to the seafood trade network based on growing populations, increasing protein demand in developing countries, shifts in production systems, and redistribution of capture and aquaculture locations are likely. The largest increases in population are projected to occur in developing countries. At the same time, the demand for seafood products is expected to increase in these countries because of the growing demand for animal protein as per capita GDPs rise (Tilman et al. 2011). This increased demand for protein in developing countries could cause greater imports and aquaculture development (Duarte et al. 2009; Bostock et al. 2010). 
Alternatively, developing countries may further increase exports of high value species and use the surplus to import staple foods (McClanahan et al. 2015) or low value seafood (Smith et al. 2010).

Marine and freshwater capture fishery production have leveled off in recent years (FAO 2014) and the increased demand for seafood products is currently being met through increased aquaculture production (Tidwell and Allan 2001). Aquaculture now comprises approximately half of the world's fish food supply, with the largest production growth in Asia (Bostock et al. 2010). The increasing Asian aquaculture production is likely a primary factor for the observed changes in international trade flows. For example, the increase in Thailand's exports (Figure 1.1), and Thailand and China's centralities in the network (Table 1.1) correspond to a period of increasing farmed shrimp exports from Thailand and overall growth in aquaculture production in China. If projections for the continued high growth rate in the aquaculture industry are correct, aquaculture production will likely continue to restructure the seafood trade network. Additionally, increases in aquaculture imports will shift the geographically distant environmental impacts of seafood production from those related to capture fisheries (e.g. bycatch, overfishing, gear abandonment, etc.) to those related to aquaculture (e.g. coastal development, water withdrawal, nutrient release, fishmeal/fish oil and crop production for feeds, etc.).

In the long-term, the seafood trade network may also be restructured by the changes in the ranges of target species that arise from global climate change (Barange et al. 2014). Cheung et al. (2010) predicts a 30-70\% increase in catch potential in high-latitudes, but a $40 \%$ decrease in the tropics by 2055. Within countries' EEZs, Norway, Greenland, Alaska in the United States and Russia are expected to have the largest increases in catch potential, while Indonesia, mainland United States, Chile, and China are expected to have the largest catch potential decreases (Cheung et al. 2010). These shifts will not only restructure the trade network, but also force the renegotiation 
of existing international fishery agreements. Such changes were already observed during a recent dispute between Iceland, Norway, the Faroe Islands and the European Union over mackerel, which have moved into new territories (Jolly 2013).

The increasing trade of food and increasing connectivity of international trade networks means that food security and sustainable food production cannot exclusively be studied with a local perspective. Adding a complimentary global systems perspective requires quality bilateral trade data. Our study analyzed aggregated seafood trade, but species-specific trade data is needed to analyze the trade of species of conservation concern and to connect seafood to the environmental impacts of its production. Hundreds of seafood species are produced using a wide variety of fishing and farming methods (Duarte et al. 2009). While fewer species comprise the majority of seafood production, there is still large variation in production methods and resource demands. For example, salmon and oysters can both be harvested wild or farmed. When farmed, oysters require few feed inputs, whereas salmon require feed inputs that vary in amount and composition (Tacon et al. 2011). Similarly, there are large differences in the water, energy, and nutrient impacts among these systems (Pahlow et al. 2015; Pelletier et al. 2009; Folke et al. 1998). This variance in environmental impacts within and among species groups suggests that detailed bilateral trade data containing species information, production method, and location production are needed to quantify the environmental impacts of traded seafood trade.

A first step toward improving data on fish trade would be to implement the changes to the Harmonized System commodity codes suggested by Chan et al. (2015). Further, data on reimports/reexports, country of origin, and production information (e.g. capture versus aquaculture) is scarce for all food trade data. Attempts to identify the geographical source of seafood requires substantial effort and several assumptions to connect total import data to mapped 
catch data (e.g. Watson et al. 2015a). Such an approach could be complimented by the trade network structure detailed here. The difficulty disentangling seafood origin causes the current global seafood trade network to mask and dilute price signals that would otherwise serve as important indicators of the state of fisheries for consumers (Crona et al. 2015). Improved trade data and product labelling would help address these missing feedbacks in the global seafood trade network. Such detailed trade data seems achievable in the future given the increasing capacity of data storage. The resulting detailed and more accurate trade data would not only improve research on sustainable food production and global food security, but it would allow for more informed policies and provide purchasing information to consumers.

This study analyzed the global seafood trade network, but it is important to note that this trade network is embedded in a larger socio-environmental network that includes marine ecosystems that support fish production, the fishing vessel and shipping transportation network, and the social and political networks of managers and market participants. Each component of the larger socio-environmental network influences the relationship of seafood production to present and future food security. A small number of seafood corporations produce and trade a large fraction of seafood products, as well as being active participants in policy-making (Österblom et al. 2015). These "keystone actors" are positioned to shape the direction of future seafood production and the marine ecosystems on which seafood relies (Österblom et al. 2015). In terms of food security, seafood trade primarily contributes to the food availability pillar of the food security framework laid out by the World Health Organization. The other two pillars of food security, food access and food use, are largely influenced by the transportation, economic, social, and political components of the larger social-ecological network. This broader socio-environmental perspective is necessary to design and implement more sustainable food supply systems. 


\section{Conclusion}

The total value of traded seafood (in real terms) nearly doubled from 1994 to 2012, with the largest trade increases occurring within regions and from exports from Southeast and Eastern Asia. These trade increases coincide with large increases in the influence of Thailand and China in the network. Concurrent with this restructuring, the overall globalization of seafood products increased, as indicated by the increasing average numbers of trade partnerships, the shift in the distribution of the number of trade partnerships, and the increasing network clustering. Applying network methods to the seafood trade data provides new insights into global seafood trade, including that the increase in trade and connectedness is similar in magnitude as the agricultural network and the increasing network influence of China and Thailand, coinciding with their periods of rapid aquaculture growth. With improved trade data consisting of detailed species, production method, and location information, this work can be extended to connect seafood trade to its specific food security and environmental impacts. 


\section{References}

Asche, F (2014) "Exchange rates and the seafood trade," GLOBEFISH Research Programme, Vol. 113. Rome, FAO, 43 p.

Asche, F, M Bellemare, C Roheim, M Smith and S Tveteras (2015) Fair enough? Food security and the international seafood trade. World Development 67: 151-160.

Barange, M, G Merino, JL Blanchard, J Scholtens, J Harle, EH Allison, JI Allen, J Holt and S Jennings (2014) Impacts of climate change on marine ecosystem production in societies dependent on fisheries. Nature Climate Change, 4: 211-216.

Bostock, J, et al. (2010) Aquaculture: global status and trends. Philisophical Transactions of the Royal Society, 365: 2897-2912.

Carr, JA, P D'Odorico, F Laio, L and Ridolfi (2012a) On the temporal variability of the virtual water network. Geophysical Research Letters, 39: L06404 doi:10.1029/2012GL051247.

Carr, JA, P D'Odorico, F Laio and L Ridolfi (2013) Recent history and geography of virtual water trade. PLoS ONE, 8(2): e55825, doi: 10.1371/journal.pone.0055825

Carr, JA, P D’Odorico, F Laio, L Ridolfi and D Seekell (2012b) Inequalities in the networks of virtual water flow. EOS Transactions, 93: 309-316.

Carr, JA, DA Seekell and P D'Odorico (2015) Inequality of injustice in water use for food? Environmental Research Letters, 10024013.

Chan, BH, H Zhang and G Fischer (2015) Improve customs systems to monitor global wildlife trade. Science, 348(6232): 291-292.

Cheung, WWL, VWY Lam, JL Sarmiento, K Kearney, R Watson, D Zeller and D Pauly (2010) Large-scale redistribution of maximum fisheries catch potential in the global ocean under climate change. Global Change Biology, 16: 24-35, doi: 10.1111/j.1365-2486.2009.01995.

Comtrade (2010) UN Commodity Trade Statistics Database. Available at: http://comtrade.un.org/db/dqBasicQuery.aspx, United Nations.

Crona, BI, TM Daw, W Swartz, AV Norström, M Thyresson, C Folke, J Hentati-Sundberg, H Österblom, L Deutsch and M Troell (2015) Masked, diluted and drowned out: how global seafood trade weakens signals from marine ecosystems. Fish and Fisheries, doi: 1111/faf.12109. 
Csardi G and T Nepusz (2006) The igraph software package for complex network research. InterJournal, Complex Systems 1695. http://igraph.org.

D'Odorico, P, JA Carr, F Laio, L Ridolfi and S Vandoni (2014) Feeding humanity through global food trade. Earth's Future, 2(9): 458-469 doi: 10.1002/2014EF000250.

D’Odorico, P, JA Carr, F Laio and L Ridolfi (2012) Spatial organization and drivers of the virtual water trade: A community-structure analysis. Environmental Research Letters, 9: 034007, doi:10.1088/1748-9326/7/3/034007.

Dalin, C, M Konar, N Hanasaki, A Rinaldo and I Rodriguez-Iturbe (2012) Evolution of the global virtual water trade network. Proceedings of the National Academy of Sciences, 109: 59895994.

Dell'Apa, A, JC Johnson, DG Kimmel and RA Rulifson (2013) The international trade and fishery management of spiny dogfish: A social network approach. Ocean \& Coastal Management, 80: 65-72.

Duarte C, M Holmer, Y Olsen, D Soto, N Marbà, J Guiu, K Black and I Karakassis (2009) Will the oceans help feed humanity? BioScience, 59: 967-976.

Fagiolo, G, J Reyes and S Schiavo (2010) The evolution of the world trade web: a weightednetwork analysis. Journal of Evolutionary Economics, 20: 479-514.

FAO (2014) The State of World Fisheries and Aquaculture 2014. Rome, 223 pp.

Folke, C, N Kautsky, H Berg, ̊̊ Jansson and M Troell (1998) The ecological footprint concept for sustainable seafood production: a review. Ecological Applications, 8(1) Supplement: S63S71.

Food and Agriculture Organization (2014) FAOSTAT database, Available at: http://faostat3.fao.org/faostat-gateway/go/to/home/E

Food and Agriculture Organization, FishStat database (2014) Available at: http://www.fao.org/fishery/topic/166235/en.

Garlaschelli, D and MI Loffredo (2005) Structure and evolution of the world trade network. Physica A, 355: 138-144.

Gephart, JA, ML Pace and P D'Odorico (2014) Freshwater savings from marine protein consumption. Environmental Research Letters, 9: 014005, doi:10.1088/17489326/9/1/014005. 
Iapadre, PL and L Tajoli (2014) Emerging countries and trade regionalization, A network analysis. Journal of Policy Monitoring, 36: S89-S110.

Jaunky, VC (2011) Fish Exports and Economic Growth: The Case of SIDS. Coastal Management, 39(4): 377-395.

Jolly, D (2013, January 28) E.U. Faces Dispute Over Mackerel Quotas. New York Times, Retrieved from http://www.nytimes.com.

Konar, M, C Dalin, S Suweis, N Hanasaki, A Rinaldo and I Rodriguez-Iturbe (2011) Water for food: The global virtual water trade network. Water Resources Research, 47(5): W05520, doi: 10.1029/2010WR010307.

Krzywinski, M, JE Schein, I Birol, J Connors, R Gascoyne, D Horsman, SJ Jones and MA Marra (2009) Circos: an Information Aesthetic for Comparative Genomics. Genome Research, 19:1639-1645.

Lin, X, Q Dang and M Konar (2014) A network analysis of food flows within the United States of America. Environmental Science \& Technology, 48(10): 5439-5447, doi: 10.1021/es500471d.

McClanahan, T, EH Allison and JE Cinner (2015) Managing fisheries for human and food security. Fish and Fisheries, 16: 78-103.

Newman, MEJ (2010) Networks: An introduction. Oxford University Press.

Österblom, H, J Jouffray, C Floke, B Crona, M Troell, A Merrie and J Rockström (2015) Transnational corporations as 'keystone actors' in marine ecosystems. PLoS ONE, 10(5): e0127533, doi:10.137/journal.pone.0127533.

Pahlow, M, PR van Oel, MM Mekonnen and AY Hoekstra (2015) Increasing pressure on freshwater resources due to terrestrial feed ingredients for aquaculture production. Science of the Total Environment, 536: 847-857.

Puma, MJ, S Bose, S Young Chon and BI Cook (2015) Assessing the evolving fragility of the global food system. Environmental Research Letters, 10, 24007, http://dx.doi.org/10.1088/1748-9326/10/2/024007.

R Core Team (2011) R: A language and environment for statistical computing. R Foundation for Statistical Computing, Vienna, Austria. ISBN 3-900051-07-0, URL http://www.Rproject.org/. 
Smith, MD, CA Roheim, LB Crowder, BS Halpern, M Turnipseed, JL Anderson, F Asche, L Bourillón, AG Guttormsen, A Khan, LA Liguori, A McNevin, MI O’Connor, D Squires, P Tyedmers, C Brownstein, K Carden, DH Klinger, R Sagarin, KA Selkoe (2010) Sustainability and global seafood. Science, 327: 784-786.

Suweis, S, A Rinaldo, A Maritan and P D'Odorico (2012) Water-controlled wealth of nations. Proceedings of the National Academy of Sciences, 110(11): 4230-4233, doi: 10.1073/pnas.1222452110.

Tacon, AGJ, M Hasan and M Metian (2011) Demand and supply of feed ingredients for farmed fish and crustaceans. FAO Fisheries and Aquaculture Technical Paper No. 564 Rome, Italy.

Tidwell, JH and GL Allan (2001) Fish as food: aquaculture's contribution. EMBO reports, 2(11): 958-963, doi: 10.1093/embo-reports/kve236.

Tilman, D, C Balzer, J Hill and BL Befort (2011) Global food demand and the sustainable intensification of agriculture. Proceedings of the National Academy of Sciences, 108(50): 20260-20264, doi: 10.1073/pnas.1116437108.

Tveterås, S, F Asche, MF Bellemare, MD Smith, AG Guttormsen, A Lem, K Lien and S Vannuccini (2012) Fish is food - The FAO's fish price index. PLoS One, 7(5): e36731. DOI: 10.1371 /journal.pone.0036731

Verburg, R, E Stehfest, G Woltjer and B Eichhout (2009) The effect of agricultural trade liberalisation on land-use related greenhouse gas emissions. Global Environmental Change, 19: 434-446.

Watson, RA, BS Green, SR Tracey, A Farmery and TJ Pitcher (2015a) Provenance of global seafood. Fish and Fisheries, DOI: 10.1111/faf.12129.

Watson, RA, GB Nowara, K Hartmann, BS Green, SR Tracey and CG Carter (2015b) Marine foods sourced from farther as their use of global ocean primary production increases. Nature Communications, 6: 7365, doi: 10.1038/ncomms8365.

The World Bank, Consumer Price Index Databank. (2015) Available at http://data.worldbank.org/indicator/FP.CPI.TOTL, accessed June 2015.

Worm, B and TA Branch (2012) The future of fish. Trends in Ecology \& Evolution, 27(11): 594599. Available at: http://dx.doi.org/10.1016/j.tree.2012.07.005.

Yang, H, L Wang, KC Abbaspour and AJB Zehnder (2006) Virtual water trade: an assessment of water use efficiency in the international food trade, Hydrology and Earth System Sciences, 10: $443-454$. 
Table 1.1: Top ten countries most central to the trade network based on eigenvalue centralities in 1994 and 2012. Eigenvalue centrality was calculated for the annual trade network constructed from UN Comtrade data.

\begin{tabular}{|c|l|l|}
\hline & 1994 Ranking & \multicolumn{1}{|c|}{ 2012 Ranking } \\
\hline 1 & United Kingdom & Thailand \\
\hline 2 & France & China \\
\hline 3 & USA & Germany \\
\hline 4 & Thailand & France \\
\hline 5 & Netherlands & USA \\
\hline 6 & Germany & Canada \\
\hline 7 & Japan & Indonesia \\
\hline 8 & Italy & United Kingdom \\
\hline 9 & Norway & Netherlands \\
\hline 10 & Spain & Spain \\
\hline & & \\
\hline
\end{tabular}


Table 1.2: Top increases and decreases in average trade flows from the time period 1994-1999 to 2008-2012. Trade values are based on UN Comtrade data, adjusted to constant 2010 USD and trade flow quantities are based on UN Comtrade data and FAO FishStat price data. Since the increases are much larger over the time period, the top 20 increases are presented to reach changes in trade flows of similar magnitude as the top 10 decreases.

\begin{tabular}{|c|c|c|c|c|c|c|}
\hline $\begin{array}{c}\text { Top } \\
\text { Increases }\end{array}$ & Exporter & Importer & $\begin{array}{c}\text { Trade } \\
\text { Difference } \\
\text { (Thousand } \\
\text { Tonnes) }\end{array}$ & Exporter & Importer & $\begin{array}{c}\text { Trade } \\
\text { Difference } \\
\text { (Million } \\
\text { USD) }\end{array}$ \\
\hline 1 & $\begin{array}{l}\text { Russian } \\
\text { Federation }\end{array}$ & China & 486 & Norway & Sweden & 2102 \\
\hline 2 & USA & China & 289 & China & USA & 2052 \\
\hline 3 & China & $\begin{array}{l}\text { Republic } \\
\text { of Korea }\end{array}$ & 271 & $\begin{array}{l}\text { Russian } \\
\text { Federation }\end{array}$ & China & 1105 \\
\hline 4 & Norway & Sweden & 263 & China & $\begin{array}{l}\text { Republic } \\
\text { of Korea }\end{array}$ & 998 \\
\hline 5 & China & USA & 216 & Vietnam & USA & 901 \\
\hline 6 & China & Nigeria & 188 & Indonesia & USA & 798 \\
\hline 7 & China & Malaysia & 163 & Norway & $\begin{array}{l}\text { Russian } \\
\text { Federation }\end{array}$ & 700 \\
\hline 8 & China & Phillipines & 161 & USA & China & 696 \\
\hline 9 & Norway & Nigeria & 152 & Spain & Italy & 571 \\
\hline 10 & Norway & China & 147 & Poland & Germany & 539 \\
\hline 11 & $\begin{array}{l}\text { Russian } \\
\text { Federation }\end{array}$ & $\begin{array}{l}\text { Republic } \\
\text { of Korea }\end{array}$ & 130 & Canada & USA & 526 \\
\hline 12 & Norway & $\begin{array}{l}\text { Russian } \\
\text { Federation }\end{array}$ & 119 & $\begin{array}{l}\text { Russian } \\
\text { Federation }\end{array}$ & $\begin{array}{l}\text { Republic } \\
\text { of Korea }\end{array}$ & 505 \\
\hline 13 & Vietnam & $\begin{array}{l}\text { Republic } \\
\text { of Korea }\end{array}$ & 113 & Thailand & USA & 504 \\
\hline 14 & China & Indonesia & 112 & Chile & Japan & 484 \\
\hline 15 & Norway & Ukraine & 111 & Chile & USA & 483 \\
\hline 16 & Sweden & Poland & 109 & China & Germany & 453 \\
\hline 17 & Canada & China & 108 & Norway & Poland & 452 \\
\hline 18 & China & $\begin{array}{l}\text { Russian } \\
\text { Federation }\end{array}$ & 106 & China & $\begin{array}{l}\text { Hong } \\
\text { Kong }\end{array}$ & 437 \\
\hline 19 & China & Thailand & 103 & Sweden & Poland & 416 \\
\hline 20 & Vietnam & USA & 101 & Sweden & France & 409 \\
\hline $\begin{array}{c}\text { Top } \\
\text { Decreases }\end{array}$ & & & & & & \\
\hline
\end{tabular}




\begin{tabular}{|r|l|l|r|l|l|r|}
\hline 1 & USA & Japan & -223 & USA & Japan & -1519 \\
\hline 2 & Hong Kong & China & -136 & Indonesia & Japan & -842 \\
\hline 3 & Indonesia & Japan & -130 & $\begin{array}{l}\text { Republic } \\
\text { of Korea }\end{array}$ & Japan & -714 \\
\hline 4 & Thailand & China & -122 & Canada & Japan & -566 \\
\hline 5 & Norway & Germany & -121 & India & Japan & -522 \\
\hline 6 & Denmark & Germany & -112 & Thailand & Japan & -368 \\
\hline 7 & $\begin{array}{l}\text { Republic of } \\
\text { Korea }\end{array}$ & Japan & -109 & Mexico & USA & -327 \\
\hline 8 & $\begin{array}{l}\text { Russian } \\
\text { Federation }\end{array}$ & Norway & -104 & Morocco & Japan & -308 \\
\hline 9 & Canada & Japan & -83 & $\begin{array}{l}\text { Russian } \\
\text { Federation }\end{array}$ & Japan & -305 \\
\hline 10 & India & Japan & -80 & Austrailia & Japan & -286 \\
\hline
\end{tabular}




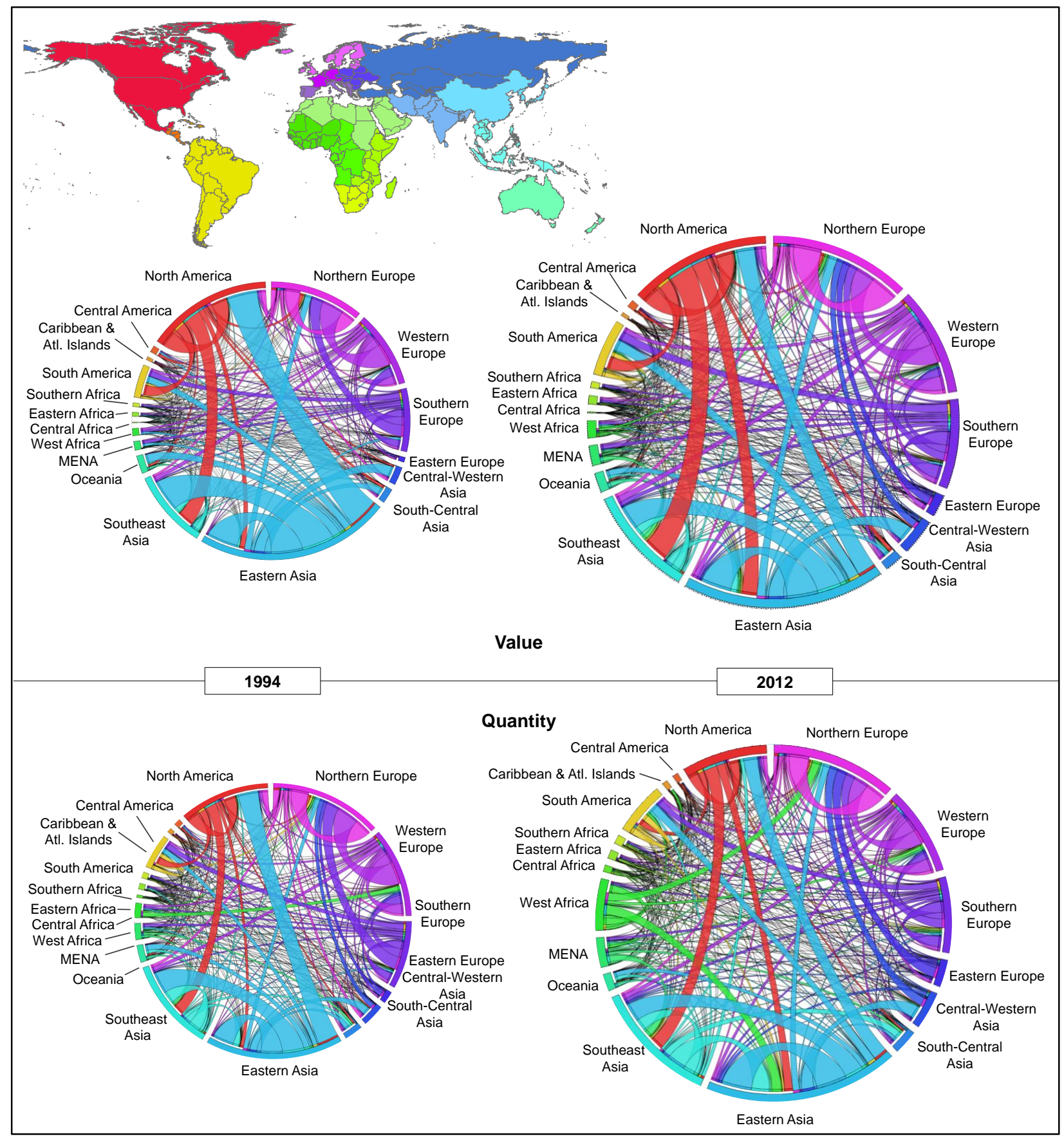

Figure 1.1: The global seafood import trade network for 1994 and 2012. The width of each band represents value (in 2010 USD) or quantity (in tonnes) traded and the band color represents the importer. The circular figure areas are scaled to the total value traded in 1994 and 2012, respectively. Note that MENA stands for Middle East and North Africa. 


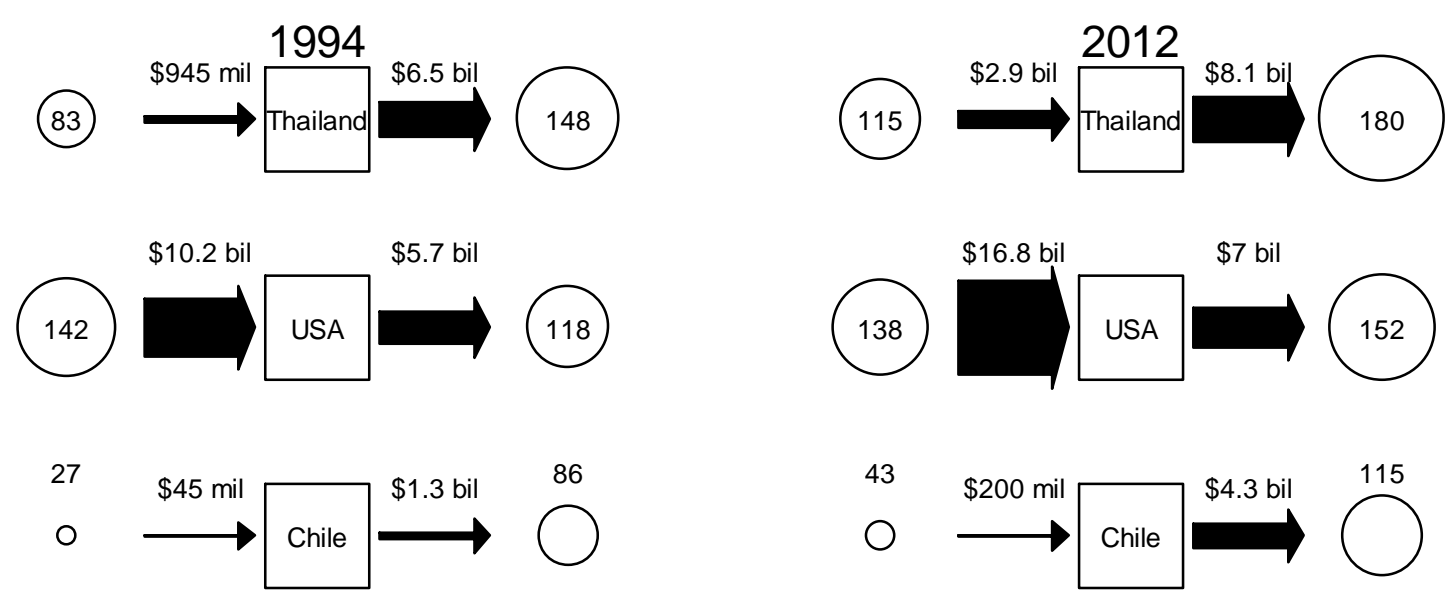

Figure 1.2: Example changes in the number of exporters (in degree), import flow, importers (out degree), and export flow for Thailand, USA, and Chile. Number of exporters and importers are indicated by the area of the circle and import/export flow (in 2010 US dollars) is indicated by the arrow width. See Appendix 1 Supplementary Figure 2 for the equivalent figure produced with quantity data. 

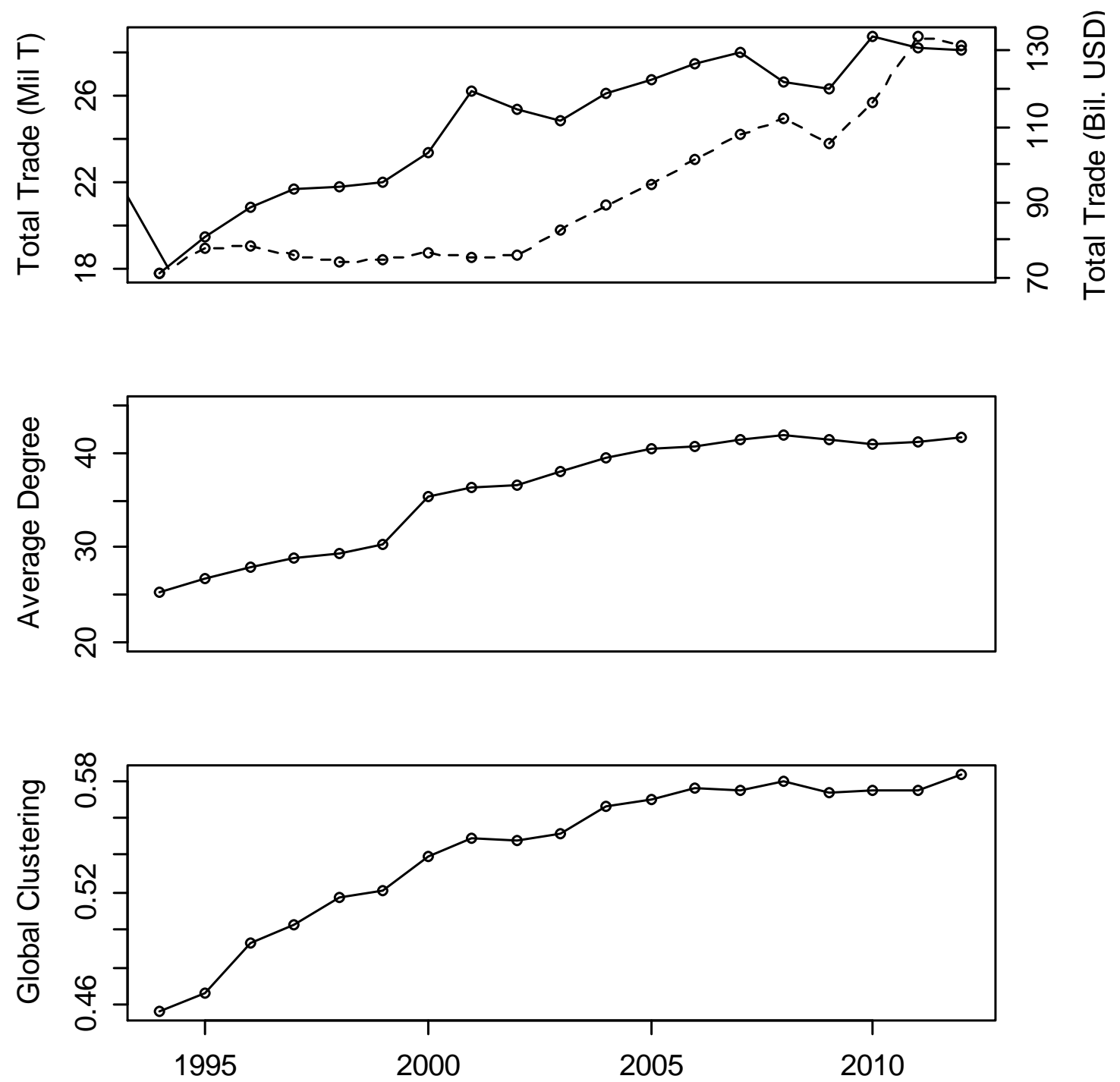

Figure 1.3: Increasing total trade (quantity in solid line and value in dashed line), unweighted degree, and unweighted global clustering coefficient of seafood trade from 1994 to 2012. Values are based on the trade network constructed from UN Comtrade data, adjusted to 2010 USD. 


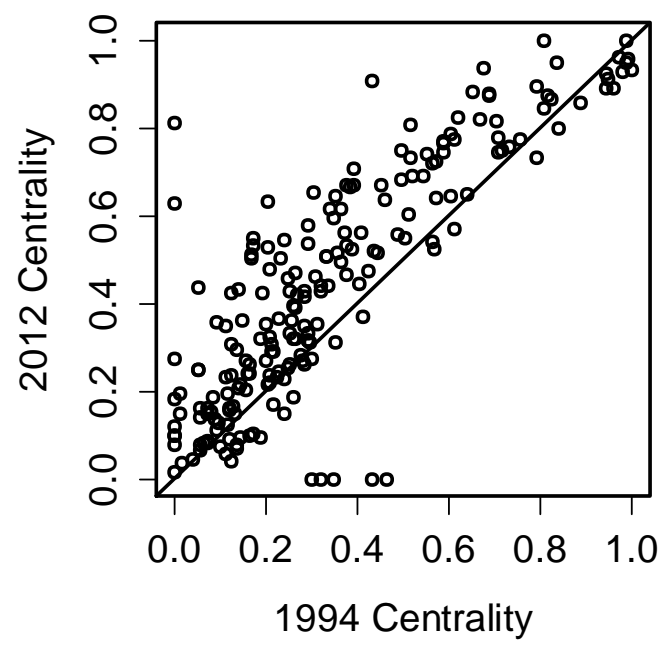

Figure 1.4: The eigenvalue centrality (a measure of the number of connections a node has as well as the connectedness of the neighbors) for each country in 1994 plotted against the eigenvalue centrality in 2012. 


\title{
CHAPTER 2: VULNERABILITY TO SHOCKS IN THE GLOBAL SEAFOOD TRADE NETWORK ${ }^{2}$
}

\begin{abstract}
Trade can allow countries to overcome local or regional losses (shocks) to their food supply, but reliance on international food trade also exposes countries to risks from external perturbations. Countries that are nutritionally or economically dependent on international trade of a commodity may be adversely affected by such shocks. While exposure to shocks has been studied in financial markets, communication networks, and some infrastructure systems, it has received less attention in food-trade networks. Here, we develop a forward shock-propagation model to quantify how trade flows are redistributed under a range of shock scenarios and assess the foodsecurity outcomes by comparing changes in national fish supplies to indices of each country's nutritional fish dependency. Shock propagation and distribution among regions are modeled on a network of historical bilateral seafood trade data from UN Comtrade using 205 reporting territories grouped into 18 regions. In our model exposure to shocks increases with total imports and the number of import partners. We find that Central and West Africa are the most vulnerable to shocks, with their vulnerability increasing when a willingness-to-pay proxy is included. These findings suggest that countries can reduce their overall vulnerability to shocks by reducing reliance on imports and diversifying food sources. As international seafood trade grows, identifying these types of potential risks and vulnerabilities is important to build a more resilient food system.
\end{abstract}

\footnotetext{
${ }^{2}$ Gephart, JA, E Rovenskaya, U Dieckmann, ML Pace and Å Brännström (2016) Vulnerability to shocks in the global seafood trade network. Environmental Research Letters, 11(3): 035008.
} 


\section{Introduction}

Currently, about one fourth of the world's food production is internationally traded (D'Odorico et al. 2014) and this proportion continues to grow. The increasing globalization of food is driven by decreasing costs of communication and transportation (Iapadre and Tajoli 2014), as well as the benefits of international trade. These benefits include increased competition and variety in international markets, access to capital investments and larger markets, and buffering against local supply shocks (sudden losses). Buffering against local supply shocks occurs when international trade provides access to food following a sudden decrease in food production in one region. However, there are also disadvantages to international trade, such as potential loss of jobs, loss of commodities domestically to higher price opportunities abroad, and exposure to shocks in other parts of the trade network.

Exposure to a shock could be realized by decreased exports from a region, which would alter the commodity prices and imports in other regions. Shock propagation in networks has previously been studied through models in financial markets, ecosystems, and in simulated networks (e.g. Kali and Reyes 2010; Gai and Kapadia 2010; Dunne and Williams 2009; Callaway et al. 2000). Recently, several studies analyzed the impacts of the 2008 grain crisis on trade, highlighting the importance of shock propagation within the food-trade system for food security and vulnerability (e.g. Acemoglu et al. 2015; Heady 2011). Nevertheless, few studies have analyzed this phenomenon for food-commodity trade networks. In order to evaluate the forward propagation of a shock (transmitted through changes in exports) in a food-trade network, we develop a model that utilizes empirical data on trade flows and includes basic economic realism through proxies for goods substitution and willingness to pay. 
We apply our model to the global trade network of fish and other aquatic foods (hereafter seafood) to quantify exposure to external shocks. While such an approach could be taken with other food commodities, we selected seafood because it is among the most highly-traded food commodities, making up around 10\% of all trade (FAO 2014) and is increasingly globalized, with a $4.5 \%$ annual real growth rate, increasing trade connectivity and is being consumed at increasingly distant locations from where it is sourced (FAO 2014; Gephart and Pace 2016; Watson et al. 2015a; Watson et al. 2015b). Further, seafood plays an important role in food security, making up nearly $20 \%$ of animal protein consumption (Kent 2003) and is impacted by multiple potential shocks including natural disasters, fishery collapses, policy changes, and price spikes in inputs (such as fossil fuels). We are interested in shocks which occur suddenly, with little warning, such that regions cannot increase production on a time-scale relevant to the time-scale of the perturbations. This framework is reasonable for many real shocks because capture fisheries generally operate at or near the highest production permitted and aquaculture requires investment and time to increase production. Within a longer time frame, aquaculture production would be expected to change in response to the shocks studied. A general equilibrium model that incorporates price responses and demand elasticity would be more appropriate to model the impacts of longer-term changes (e.g. Delgado et al. 2003). However, focusing on sudden shocks is of particular interest because even temporary decreases in protein and micronutrient availability can have important food security and development impacts. While micronutrient deficiency is less apparent than staple crop shortages, this 'hidden hunger' also plays a critical role in development and food security (McClanahan et al. 2013).

Hypothetical shocks are analyzed to observe the behavior of shock propagation in the system, but represent real scenarios. For example, fishery collapses or closure of fisheries to 
prevent collapses can both serve as a shock to the fish trade network. Natural disasters also cause a shock when fishing gear and infrastructure are destroyed. This occurred in 2004, when the Caribbean experienced four large hurricanes that damaged or destroyed over 140 of the 720 fishing vessels and harmed fishing trade infrastructure (Westlund et al. 2007). Similarly, in 2002, a typhoon in the Philippines damaged pond infrastructure and resulted in an estimated 2000-3000 metric tonnes of lost fish production (Westlund et al. 2007). Environmental disasters are also a source of shocks. For example, the Exxon Valdez oil spill in 1989 resulted in the complete closure of the Alaskan fishery, which annually had produced 240,000 tons of fish (Westlund et al. 2007). Aquaculture production is subjected to shocks as well, including extreme cold temperatures during winter that kill fish in ponds (Westlund et al. 2007), and diseases that spread rapidly through fish farms. Since many aquaculture and capture fishery systems are heavily-dependent on fossil fuels, energy price spikes could impose a shock to seafood production (Pellitier et al. 2014).

In order to assess the food security implications of sudden shocks, in this study we consider the results within the vulnerability framework used by Allison et al. (2009), which is an extension of the Intergovernmental Panel on Climate Change vulnerability framework (IPCC 2001). They highlight three components of vulnerability: exposure, intrinsic sensitivity, and adaptive capacity. Exposure measures the impact that a region is likely to experience, intrinsic sensitivity represents the economic and food security dependence on the natural resource, and adaptive capacity indicates the ability for the impacts in the region to be offset. In our study we measure the exposure as the percent of a shock that ends up in each region. This is quantified through a shock propagation model. However, the food security outcomes of decreased seafood supply likely differ for regions consuming luxury seafood products versus non-luxury goods and the degree to which individuals have access to substitute foods. As a proxy to account for this, we compare modeled regional 
exposure to data on intrinsic sensitivity (dependency on seafood, calculated as the percent of animal protein derived from seafood). We then also compared our modeled exposure and the calculated sensitivity to existing adaptive capacity indices to account for regions' abilities to offset shocks through governance, infrastructure, and socio-economic factors in order to reveal overall regional vulnerabilities to shocks in the network.

\section{Methods}

\section{Data description}

We construct the global seafood trade network using the United Nations' Comtrade database (Comtrade 2010) following Gephart and Pace (in press). This database contains selfreported annual import and export bilateral trade flows (in US dollars). This network represents seafood products destined for human consumption (selected from Harmonized System codes 03 and 16) during the year 2011. In order to convert the trade flows from dollars to quantities, average tonnes imported per dollar is calculated for each country using the Food and Agricultural Organization (FAO) FishStat database (2013), which provides total tonnes and value (in US dollars) imported for each country. This conversion factor is then applied to each country's imports to generate a network of seafood trade in tonnes. A linear regression of the sum of the quantity of imports in the resulting network versus the reported total imports in the FishStat database indicated a close-to-linear relationship $\left(r^{2}=0.96\right)$ with a slope of 0.91 (p-value<0.001). The regression between the sum of the quantity exported and the exports reported in FishStat also shows a close relationship $\left(\mathrm{r}^{2}=0.98\right.$, slope $=0.94, \mathrm{p}$-value $\left.<0.001\right)$. The slopes near one and high $\mathrm{r}^{2}$ indicate that the magnitude and patterns of the network used for this analysis agree well with FishStat. The trade network is depicted in Figure 2.1 using Circos (Krzywinski 2009). 
Per capita calculations use 2011 population size from the FAOSTAT (2014) database. In order to evaluate the effect of allowing wealthier regions with higher willingness to pay to pass on more of the shock, gross national product (GDP) per capita data for 2011 from The World Bank (2014) is used to modify the distribution of shock (described below). To evaluate vulnerability, we compared exposure to the percent of animal protein derived from fish from FAOSTAT (2014).

\section{Model description}

The spread of shocks within the seafood trade network and resulting changes in fish supply are investigated using a forward-propagation model. Our model builds on the ecosystem model of energy perturbations by Hannon (1973). We modify this approach so that the fish exports from one region are decreased to represent a perturbation, and this shock to the system is then propagated throughout the network based on the network structure and basic economic features. Shocks are transmitted by decreased exports from one region reducing the flows to importing regions. Regions with reduced imports can then either reduce their own exports, thus passing on the shock, or reduce their domestic fish supply, thus absorbing the shock locally. The resulting model is structurally similar to a recent, independently-developed model evaluating shocks in the virtual water-trade network (Tamea et al. 2016).

In reality the reduction of exports versus reduction of domestic consumption depends on the volume of exports available to reduce, available substitute goods, and the local price sensitivity to changes in seafood price that result from decreased supplies. In our model, substitutability is accounted for by decreasing the percent of the shock being passed on at each iteration, while willingness to pay is represented as a function of GDP per capita. Since many of the necessary economic parameters to model substitution and price sensitivity are unavailable, the amount of shock being passed on (parameter $q$ ), and the influence of GDP per capita on how the shock is 
distributed (parameter $\alpha$ ) are each varied to explore the influence of substitution and price sensitivity on which regions absorb the shock (see Equation 5). A decrease in seafood supply through the portion of the shock which is not passed on $(1-q)$ encompasses both substitution with non-seafood commodities and a decrease in seafood consumption which is not replaced by other foods. In order to identify the cases where decreased supply is likely more relevant to food security, the decreased supply (exposure) is compared to dependence on seafood (sensitivity).

We consider $n$ trading partners and let $F_{t}$ be the matrix of trade flows between the partners at each discrete iteration $t=1,2, \ldots$..Depending on the context, we refer to a trading partner as a node, an exporter, or an importer. The column sums of $F_{t}$ represent the total exports from each exporter, $e_{t, k}=\sum_{j=1}^{n} F_{t, j k}$, and the row sums represent the total imports to each importer, $i_{t, j}=$ $\sum_{k=1}^{n} F_{t, j k}$. We assume that the initial trade flows, $F_{0}$, are determined from the United Nations' Comtrade database as described in the previous section, i.e. $F_{0}=F^{\text {data }}$.

To investigate the effect of a perturbation to the trade network, we assume that a shock at iteration $t=1$ reduces the exports of a node $\hat{\jmath}$ by a fraction $s, 0 \leq s \leq 1$. Specifically, $e_{1, \hat{\jmath}}=(1-$ $s) e_{0, \hat{\jmath}}$ while $e_{1, j}=e_{0, j}$ for $j \neq \hat{\jmath}$. Thus the shock received by node $j$ at iteration $t=1$ is given by $\Delta i_{1, j}=i_{1, j}-i_{0, j}$. We assume that a proportion $q, 0<q<1$, of a received shock is passed on from imports to exports in each iteration and the amount of passed shock is distributed over its receivers through the altered trade flows according to a given transfer matrix $T_{t}$. So, an amount $(1-q) \Delta i_{1, j}$ of the shock is absorbed at node $j$ and the remaining part $q \Delta i_{1, j}$ is to the extent possible passed forward to trading partners. Nodes are unable to pass on the shock when their exports become zero. At that point, any additional shock passed to that node is absorbed locally rather than being passed on. Specifically, we let $F_{1, j k}=\left[T_{j k}\left(e_{0, j}-q \Delta i_{1, j}\right)\right]^{+}$be the new trade 
flow from node $j$ to node $k$; here and in what follows superscript plus sign is used to indicate the maximum of the value in the parenthesis and 0. Iteratively, we define the 'perturbed' dynamics as follows

$F_{t+1, j k}=\left[T_{j k}\left(e_{\mathrm{t}, j}-q \Delta i_{t+1, j}\right)\right]^{+}$

$\Delta i_{t+1, j}=i_{t+1, j}-i_{t, j}$

Iterations are continued until all of the shock has been distributed $\left(t=t^{\text {equil }}\right)$. The change in fish supply, or exposure of a node to a shock, is given by,

$\mathrm{c}_{k}=\sum_{t=1}^{t^{\text {equil }}}\left[(1-q) \Delta i_{t, k}+\left(q \Delta i_{t, k}-e_{t, k}\right)^{+}\right]$

There are different ways to define the transfer matrix $T$; in the simplest case we assume that the received shock is passed on in proportion to exports. Proportional propagation of shocks is empirically supported (Tamea et al. in press). In this case the elements of the transfer matrix are given by

$T_{j k}=\frac{F_{0, j k}}{e_{0, j}}$

In order to incorporate the effect of larger willingness to pay of richer countries, we modify (4) as follows

$T_{j k}=\frac{F_{0, j k} g_{k}^{\alpha}}{\sum_{k^{\prime}=1}^{n} F_{0, j k^{\prime}} g_{k^{\prime}}^{\alpha}}$

where $g_{k}$ is the per capita GDP of country $k$, serving as a proxy of the country's willingness to pay; $\alpha \geq 0$ is the degree of per-capita GDP influence on the distribution of the shock. When $\alpha=0$, the transfer of the shock does not depend on per-capita GDP and is proportional to exports. As $\alpha$ 
increases, the adjusted trade flows will be increasingly directed to countries with higher per-capita GDP. In this way, we account for consumers in high-income countries that tend to be less pricesensitive and therefore their seafood purchases may not be substantially reduced by the higher prices, resulting in more of the shock being passed to the lower per capita GDP countries. Although this means that the trade flows will be altered even in the absence of a shock, $\alpha$ values were selected to have a limited impact on the distribution of trade in $t^{\text {equil }}$ iterations. The end result of using this expression for the transfer matrix is similar to that of a larger degree of the shock being transmitted to countries with lower per capita GDP. While $\alpha$ is varied to assess the impact of including a willingness to pay proxy, $\alpha$ is set to zero for all other results presented.

It should also be noted that for the case of small shocks, a closed formula can be derived (See appendix for formula and derivation). This closed formula applies for shocks which are small enough such that no node reaches the threshold point of not being able to further reduce its exports.

The above model was run for a range of parameter values from 0 to 1 in increments of 0.1 for $s, q$, and for the values $0,0.01,0.05,0.1,0.5,1,5$, and 10 for $\alpha$. The different values of $s$ represent different degrees of shock, to explore the effect of shocks of different magnitudes that could occur, whereas different values of $q$ and $\alpha$ are explored because their values are unknown and difficult to parameterize empirically.

\section{Model robustness}

In our simulations $50 \%$ of the shock was absorbed for all $q$ values after 10 iterations and $80 \%$ was absorbed after 20 iterations. The shock is absorbed much more rapidly when the percent of shock being passed on at each iteration is decreased (Appendix 2, Supplementary Figure 1). In addition to decreasing the percent of the shock remaining at each iteration, increasing the percent of the shock passed on at each iteration shifts the distribution of countries absorbing the shock 
(Appendix 2, Supplementary Figure 2). For example, when little shock is passed on (a low degree of spread), the majority of the shock is absorbed by the regions importing from the perturbed regions. However, when more of the shock is passed on at each iteration (a high degree of spread, q), the shock is absorbed by only a few regions, notably West Africa and Central Africa. We assume that all regions have the same propensity for passing on shocks, i.e., each are assigned the same value of the parameter $q$, but the present model could be extended by allowing different values of $q$. We show that the main model results are robust to reasonable and independent variation in $q$ across regions in the Supplementary Information.

Further, while larger shocks generate larger decreases in fish supply, the propagation and distribution of the shock is robust to the degree of the shock imposed (Appendix 2, Supplementary Figure 3). Although extreme degrees of shock may be unlikely to occur, studying hypothetical extremes is useful to understand system behavior and resilience (Ilmola et al. 2013). The remaining analyses represent an average over a uniform distribution of the degree of shock, but the patterns observed are scalable to smaller or larger perturbations. In order to illustrate the variation in the impact of shock across the parameters, regional exposure is explored across parameter values for the percent of shock passed on, with the GDP influence held at zero (Appendix 2, Supplementary Figure 3), and then is explored for the median percent of shock passed on, with varying GDP influence (Figure 2.4).

\section{Results}

At the regional level trade links exist between nearly all pairs of regions (Figure 2.1). Regions with the largest total imports and exports, including Northern Europe, North America, and Eastern and Southeast Asia, are indicated by the wide flow bands. The largest trade flows are 
from Eastern and Southeast Asia to North America, from North America to Eastern Asia, from Southeast Asia to Eastern Asia, and from Northern Europe and Eastern Asia to West Africa.

Net importers and regions importing from more regions are more exposed to shocks

A feature of the model is that exposure increases with increasing imports and number of regions from which a region imports (Figure 2.2). These two features are intuitive given that regions which import large volumes of seafood can be passed more of a shock and regions importing from more regions are passed shocks more often and from more directions. The regions with the highest exposure to external shocks are West Africa, Eastern Asia, and Southern and Western Europe. Each of these regions falls relatively high in gross seafood imports and in the number of regions from which they import (Figure 2.2). While there is no significant linear relationship between gross seafood exports and exposure, low exports can help explain the high exposures of Central and West Africa. Regions with low exports are more likely to reach the threshold point where they cannot decrease their own exports and pass the shock on. Instead, at this threshold all shock passed to them must be absorbed locally as a decrease in seafood supply. This feature of the model supports previous findings that dependence on imports for staple crops increased countries' exposures to grain shocks, specifically the 2008 grain crisis (Puma et al. 2008). Thus despite the food security benefits that arise from international trade, over-reliance on importing major food commodities exposes countries to external shocks.

The regions which are most exposed to shocks initiated in any given region are Central and West Africa, Eastern Asia, and Southern and Western Europe, indicated by the row of dark cells in Figure 2.3. However, some regions are highly exposed to shock in particular other regions. For example, $44 \%$ of a shock initiated in the Caribbean and Atlantic ends up in West Africa, $36 \%$ of a shock initiated in Central Western Asia ends up in Eastern Asia, and 33\% of a shock initiated in 
Eastern Europe ends up in Western Europe (Figure 2.3). As a result, the effect of a particular shock is dependent on the network structure and can have a relatively large impact on a region that does not have high exposure on average. However, these regions are not necessarily the largest importers from the region where the shock was initiated, which agrees with the findings by Tamea et al. (2016). There is also variation in the effect of a particular shock based on the percent of shock passed on at each step, particularly for West and Central Africa (Appendix 2, Supplementary Figure 4).

Exposure is quantified as the percent of a shock ending up in each region, but regions with greater exports can impose a larger shock on the network. When multiplied by the magnitude of the initial shock, the largest supply decreases occur due to the Northern Europe, Eastern Asia, and Southeast Asia, implying these regions exhibit the most influence, or power, within the trade network. Specifically, the largest supply decreases occur in West Africa (from a shock initiated in Northern Europe or Eastern Asia), in Eastern Asia (from a shock initiated in Southeast Asia), or in North America (from a shock initiated in Southeast Asia). The next largest decreases across the parameters occurred in Western Europe (from shocks initiated in Western or Northern Europe, or Southeast Asia) and in West Africa (from shocks initiated in Southeast Asia, South America, West Africa, or Western Europe). This finding is robust across the range of values for the propensity to pass shock on and for the influence of GDP.

Regions with higher GDPs would likely also have a higher average willingness to pay for seafood and could purchase the seafood at a higher price under a shock scenario. This would cause shocks to dissipate in that region. To explore regional exposure in the case where regions that are less price-sensitive receive less of the shock, a GDP effect was incorporated by altering the distribution of the shock (represented in the model by increasing $\alpha$ ). As the influence of GDP 
increases, the distribution of the shock shifted such that the poorest countries absorbed more of the shock (Figure 2.4). This caused an increasing percent of the shock to end up in West Africa, making West Africa even more exposed to shocks.

\section{Central and West Africa are the most vulnerable to shocks}

Comparing exposure within the trade network to intrinsic sensitivity reveals several general features of vulnerability to shocks to seafood exports (Figure 2.5). West and Central Africa stand out as having relatively high exposure and sensitivity to shocks. While Western, Northern, and Southern Europe are also among the most exposed regions, they have relatively low sensitivity since a small percent of dietary animal protein is derived from seafood. Conversely, Southeast Asia has high sensitivity, but low exposure for most parameter values, which is partially explained by the region's comparatively high net exports. This result is an average over the region where the shock is initiated, but there can be higher vulnerability for specific perturbed regions (e.g. West Africa has high exposure to a shock originating in the Caribbean and Atlantic Islands). These comparisons only consider relative vulnerabilities. Moving from relative vulnerability to absolute vulnerability requires analysis with data on domestically-produced seafood protein, demographic distribution within each region, and the distribution of access to alternative protein sources. The demographic distribution and corresponding protein requirements is an important consideration for assessing vulnerability in more absolute terms because children, pregnant women, and individuals engaging in physical labor require higher intake of protein (National Research Council 2005).

Since the parameters controlling the spread and influence of GDP shift the distribution of the shock at equilibrium and the resulting exposure within the network, these parameters can change which regions are most vulnerable within the network. While the results of Figure 2.5 
depict an average over the degree of spread and do not include the influence of GDP, one can infer the effects of shifting these parameters on vulnerability from Appendix 2, Supplementary Figures 2 and 4. A higher degree of spread would result in West and Central Africa being more exposed, which would result in increased relative vulnerability. When a GDP effect is included, more of the shock ends up in West Africa. This would increase the exposure of each of these regions, which is particularly important for West Africa's vulnerability due to its high dependence on fish protein (West Africa has the second highest fish protein dependency).

The third component of vulnerability is adaptive capacity, or the potential, or ability of a system to adjust in response to a change (IPCC 2001). A region's adaptive capacity is comprised of factors such as levels of societal and human capital, and the effectiveness of governance structures (Allison et al. 2009). In a study of the vulnerability of national economies to the effects of climate change on fisheries, Allison et al. (2009) used an adaptive capacity index consisting of healthy life expectancy, education, governance, and size of economy. The lowest adaptive capacity indices were concentrated in Africa and tropical Asia. The low adaptive capacity of nearly all countries in Africa combines with the high exposure and sensitivity of African regions observed in this study to reveal relatively high overall vulnerability of these regions.

With relatively high exposure, high sensitivity, and low adaptive capacity, we find West and Central Africa to be the most vulnerable to shocks in the seafood trade network. This finding adds to previous research on the impacts of international seafood trade on the poor in sub-Saharan Africa. While Béné et al. (2010) found no direct benefits or negative impacts from international seafood trade on the poor in sub-Saharan Africa, our results suggest potential indirect negative impacts of international trade on West and Central Africa. This finding also agrees with Puma et 
al. (2015) that least developed countries suffer the greatest losses due to supply disruptions in highly connected networks.

\section{Discussion}

The results of this study suggest a number of general implications for reducing national vulnerabilities to external shocks. The first is to reduce exposure to shocks by improving a country's trade balance and domestic production. Future seafood production is projected to come from aquaculture, but sub-Saharan Africa has been lagging in aquaculture development and currently represents less than one percent of the world's aquaculture production (FAO 2014). This is particularly relevant since West and Central Africa are among the most vulnerable regions to shocks. However, the region's significant land and water resources suggest the potential for substantial aquaculture growth (Subasinghe et al. 2009). As a result, future support for aquaculture development in these regions may reduce these countries' exposure to external shocks.

Vulnerability to shocks can also be lessened by reducing sensitivity and increasing adaptive capacity. Sensitivity can be reduced by increasing food source diversity through both trade and domestic production. Since adaptive capacity indices represent multiple social and economic factors, including healthy life expectancy, education, governance, and size of economy, there are no single or simple recommendations for improving adaptive capacity. However, by building adaptive capacity countries will reduce vulnerability to other threats, including climate change and some components of this increased adaptive capacity would contribute to other aspects of food security.

Since major exporters can impose larger shocks within the network, international trade policy should aim to minimize potential primary or secondary shocks originating in these regions. This study did not consider any secondary shock scenarios, but a potential secondary shock would 
be a country imposing export bans to protect domestic access to seafood. For example, a protectionist act similar to India's non-Basmati rice export ban in 2007, which contributed to the 2008 grain crisis. This ban on exports was enacted to protect domestic consumers from high wheat prices following a poor harvest season (Christiaensen 2009). Another potential secondary shock could occur if higher fish prices that result from decreased supply lead to increased pressure in other fisheries in the network and cause a collapse. While not explored here, such secondary shocks could occur in the system and would intensify the impacts of an initial shock, particularly when occurring in an influential country.

Vulnerability to external shocks should be considered as indirect risks of trade when crafting seafood trade policies, particularly when shocks are disproportionately experienced by developing countries. However, indirect risks must be considered on balance with the direct benefits countries can experiences from seafood trade. These direct benefits from trade can vary greatly between countries. For example, seafood trade benefits food security in some countries with large offshore fisheries, such as Namibia, but not in countries with coastal fisheries, such as Ghana, Philippines, and Kenya (Kurien 2004). These benefits of seafood trade to food security are largely derived from employment in the fishery sector, which promotes economic growth and the ability to purchase other foods (Jaunky 2011). Further, each of the vulnerability assessments presented represents an average over a number of countries, ignoring the heterogeneity in exposure and sensitivity within countries. While this study focused on the regional and national level, promoting food security at the subnational level requires policies which ensure the benefits of trade across socioeconomic groups.

Our method represents an alternative approach to models of the economic impacts of disasters using Input-Output models, which use the interrelationships of sectors to model shock 
propagation through intermediate changes in consumption and demand (Hallegatte 2008). By modelling the fish imports and exports based on how much of the shock is being passed on and how the shock is distributed, we imply interdependencies with other sectors, but do not assess the impact of a shock to fisheries on these other sectors explicitly. For example, while not studied here, shocks to seafood production would also disrupt employment and income in fisheries sectors. This would likely have negative impacts on the nutrition and wellbeing of local fishery workers. Our approach allows for the analysis of patterns of exposure to shocks that hold for most parameter values and arise from the network structure and trade flows. While the model and results we have presented demonstrate vulnerabilities based on the trade network structure and some basic economic features, more detailed quantification of substitution, evaluation of the percent of shock passed on and context-specific modeling is needed to develop specific seafood trade policies that reduce risk of exposure and promote overall food security.

\section{Conclusion}

The food system is increasingly globalized, which allows for buffering against local shocks, but exposes regions to external shocks. Evaluating exposure to such shocks helps assess vulnerability and risk within the global food system. Here we studied the response of the global seafood trade network to potential environmental and policy perturbations by modeling how negative local impacts propagate through the trade network and how trade flows are redistributed. Vulnerability to shocks in the network was assessed by comparing changes in national fish supplies to indices of each country's nutritional seafood dependency. The regions with higher imports, notably West Africa, Eastern Asia, and Southern and Western Europe tended to be most exposed within the network. As major exporters, Northern Europe, Eastern Asia, and Southeast Asia have the most significant influence initiating shocks in the network. Comparing exposure to sensitivity, 
revealed West and Central Africa to be relatively vulnerable to shocks within the network, with West Africa becoming increasingly vulnerable when a GDP effect was included. The vulnerability of these regions is further emphasized by the low adaptive capacity previously reported in nearly all African countries. The methods developed in this study represent an approach to understanding how shocks are transmitted and where the highest risks are to external shocks in a food commodity trade network. Further development and extension of the analysis presented is an important step in building a more resilient food system. 


\section{References}

Acemoglu, D, A Ozdaglar and A Tahbaz Salehi (2015) Networks, shocks, and systemic risk. Working Paper 20931, National Bureau of Economic Research.

Allison, EH, AL Perry, MC Badjeck, WN Adger, K Brown, D Conway, AS Halls, GM Pilling, JD Reynolds, NL Andrew, and NK Dulvy (2009) Vulnerability of national economies to the impacts of climate change on fisheries. Fish and Fisheries, 10: 173-196.

Béné, C, R Lawton and EH Allison (2010) "Trade Matters in the Fight Against Poverty":

Narratives, Perceptions, and (Lack of) Evidence in the Case of Fish Trade in Africa. World

Development, 38(7): 933-954.

Callaway, DS, MEJ Newman, SH Strogatz and DJ Watts (2000) Network Robustness and Fragility : Percolation on Random Graphs. Physical Review Letters, 85(25): 5468-5471.

Comtrade. 2010. UN Commodity Trade Statistics Database. Available at: http://comtrade.un.org/db/dqBasicQuery.aspx, United Nations.

Christiaensen, L (2009) Revisiting the global food architecture: Lessons from the 2008 food crisis. World Institute for Development Economics Research, Discussion Paper No. 2009/04.

D’Odorico, P, J Carr, L Francesco, L Ridolfi and S Vandoni (2014) Feeding humanity through global food trade. Earth's Future, 2(9): 458-469.

Delgado, CL, N Wada, MW Rosegrant, S Meijer and M Ahmed (2003) Fish to 2020: Supply and demand in changing global markets. WorldFish Center Technical Report 62, Washington, D.C.

Dunne, JA and RJ Williams (2009) Cascading extinctions and community collapse in model food webs. Philosophical Transactions of the Royal Society B, 364:1711-1723.

Food and Agriculture Organization (2014) The State of World Fisheries and Aquaculture 2014. Rome. 223 pp.

Food and Agriculture Organization (2014) FAOSTAT database, Available at: http://faostat3.fao.org/faostat-gateway/go/to/home/E

Food and Agriculture Organization of the United Nations (2013) FishStat database, Available at: http://data.fao.org/ref/babf3346-ff2d-4e6c-9a40-ef6a50fcd422.html?version=1.0

Gai, P and S Kapadia (2010) Contagion in financial networks. Proceedings of the Royal Society A, 466(2120): 2401-2413, doi: 10.1098/rspa.2009.0410 
Gephart, JA and ML Pace (2015) Structure and evolution of the global seafood trade network. Environmental Research Letters, 10(12): 125014.

Hallegatte, S (2008) An adaptive regional input-output model and its application to the assessment of the economic cost of Katrina. Risk Analysis, 28: 779-799.

Hannon, B (1973) The structure of ecosystems. Journal of Theoretical Biology, 41: 535-546.

Headey, D (2011) Rethinking the global food crisis: the role of trade shocks. Food Policy 36: 136146.

Iapadre, PL and L Tajoli (2014) Emerging countries and trade regionalization: A network analysis. Journal of Policy Modeling, S89-S110.

Ilmola, L, B Park and J Hyun Yoon (2013) Resilience by shock testing. Innovation and Supply Chain Management, 7(2): 058-065.

IPCC (2001) Climate Change 2001: Impacts, Adaptation \& Vulnerability, Contribution of Working Group II to the Third Assessment Report of the Intergovernmental Panel on Climate Change, Vol. Cambridge University Press, Cambridge.

Jaunky, VC (2011) Fish Exports and Economic Growth: The Case of SIDS. Coastal Management, 39(4): 377-395.

Kali, R and J Reyes (2010) Financial contagion on the international trade network. Economic Inquiry, 48(4): 1072-1101.

Kent, G (2003) Fish trade, food security and the human right to adequate food. In: Report of the FAO Expert Consultation on International Fish Trade and Food Security Casablanca, Morocco 27-30 January 2003. FAO Fisheries Report No. 708, FAO, Rome, pp. 49-70.

Krzywinski, M, JE Schein, I Birol, J Connors, R Gascoyne, D Horsman, SJ Jones and MA Marra (2009) Circos: an Information Aesthetic for Comparative Genomics. Genome Research, 19:1639-1645.

Kurien, J (2004) Fish Trade for the People: Toward Understanding the Relationship Between International Fish Trade and Food Security. Food and Agriculture Organization of the United Nations and the Royal Norwegian Ministry of Foreign Affairs, Rome.

McClanahan, T, EH Allison and JE Cinner (2013) Managing fisheries for human and food security. Fish and Fisheries, 16: 78-103. 
National Research Council (2005) Dietary Reference Intakes for Energy, Carbohydrate, Fiber, Fat, Fatty Acids, Cholesterol, Protein, and Amino Acids (Macronutrients). Washington, DC: The National Academies Press.

One World Nations Online (2014) Countries and regions of the world from A to Z. http://www.nationsonline.org/oneworld/countries_of_the_world.htm.

Pellitier, N, J André, A Charef, D Damalas, B Green, R Parker, R Sumaila, G Thomas, R Tobin and R Watson (2014) Energy prices and seafood security. Global Environmental Change 23: $30-41$.

Puma, MJ, S Bose, S Young Chon and BI Cook (2015) Assessing the evolving fragility of the global food system. Environmental Research Letters, 10, 24007, http://dx.doi.org/10.1088/1748-9326/10/2/024007.

Subasinghe, R, D Soto and J Jia (2009) Global aquaculture and its role in sustainable development. Reviews in Aquaculture, 1:2-9.

Tamea, S, F Laio and L Ridolfi (2016) Global effects of local food-production crises: a virtual water perspective. Scientific Reports, 6: 18803.

Watson, RA, BS Green, SR Tracey, A Farmery and TJ Pitcher (2015a) Provenance of global seafood. Fish and Fisheries, doi: 10.1111/faf.12129.

Watson, RA, GB Nowara, K Hartmann, BS Green, SR Tracey and CG Carter (2015b) Marine foods sourced from farther as their use of global ocean primary production increases. Nature Communications, doi: 10.1038/ncomms8365.

Westlund, L, F Poulain, H Båge and R van Anrooy (2007) Disaster response and risk management in the fisheries sector. FAO Fisheries Technical Paper 479.

The World Bank (2014) GDP (Current US\$). Available at: http://data.worldbank.org/indicator/NY.GDP.MKTP.CD. 


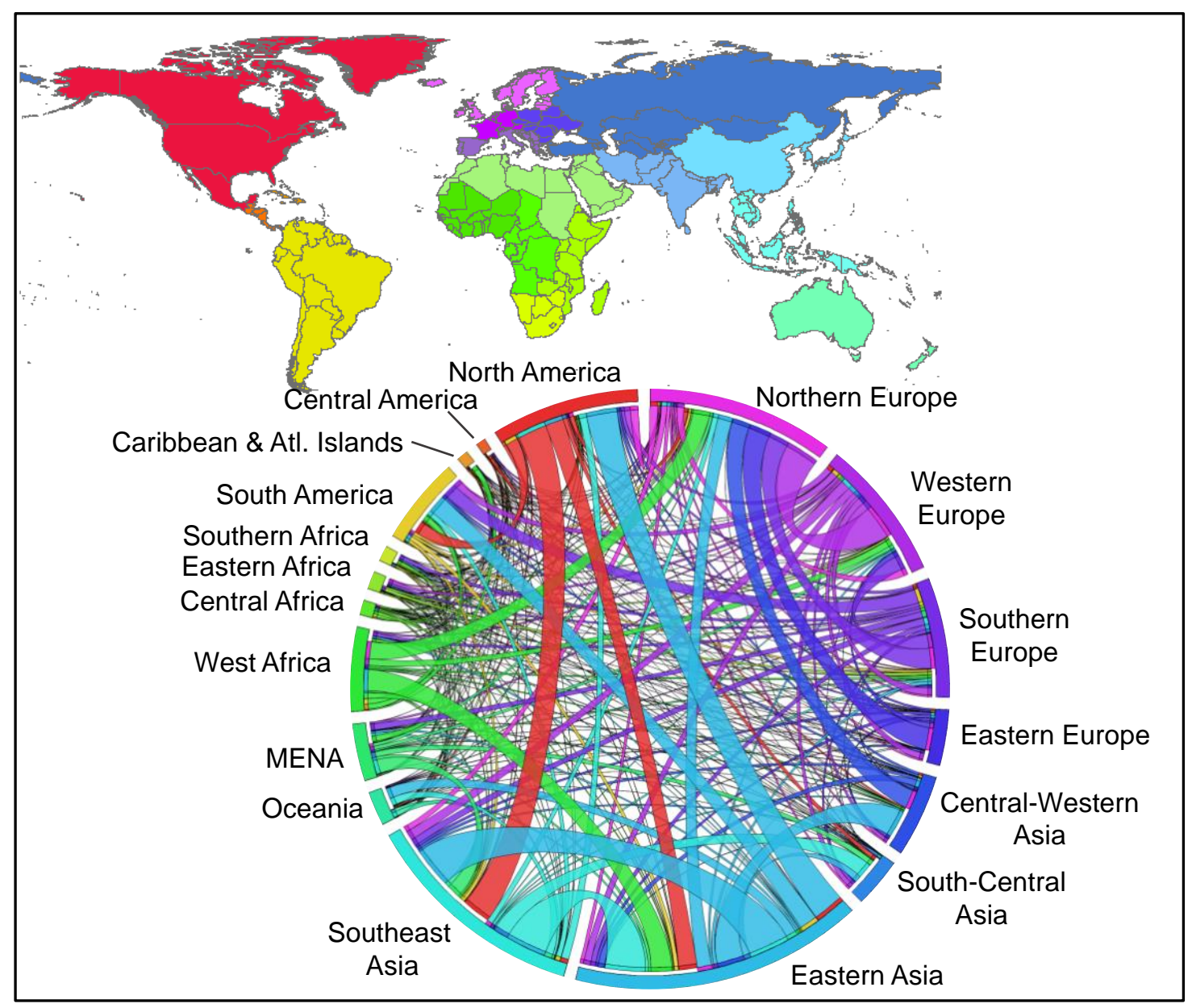

Figure 2.1: Global seafood trade among regions represented as color groups. The width of each band represents quantity traded (tonnes per year), and the band color represents the importer. Note that MENA stands for Middle East and North Africa. 
a

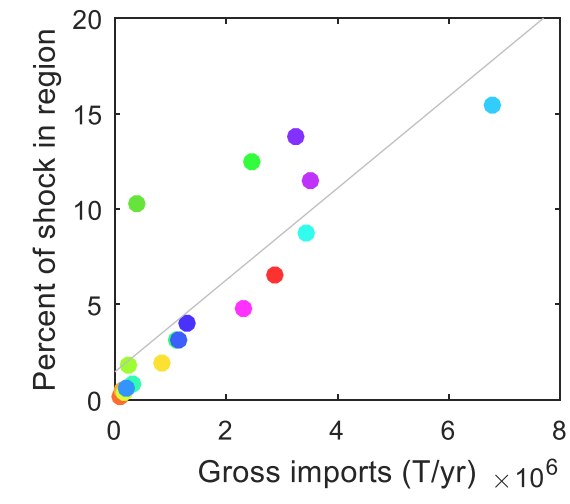

\begin{tabular}{|l|}
\hline Northern Europe \\
Western Europe \\
Southern Europe \\
Eastern Europe \\
Central Western Asia \\
South Central Asia \\
Eastern Asia \\
Southeast Asia \\
Oceania \\
MENA \\
West Africa \\
Central Africa \\
Eastern Africa \\
Southern Africa \\
South America \\
Caribbean Atlantic \\
Central America \\
North America \\
\hline
\end{tabular}

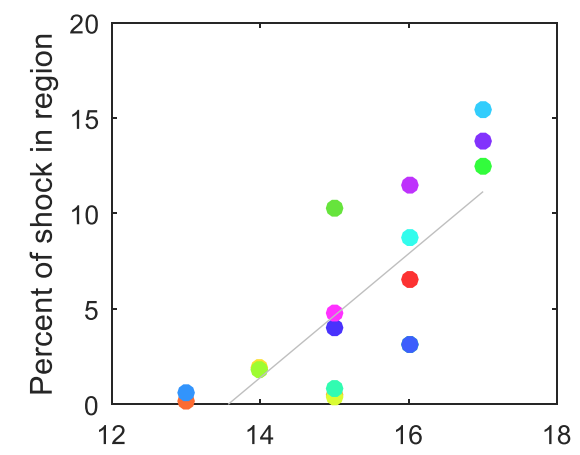

No. regions imported from

Figure 2.2: Exposure (measured as percent of initial shock ending up in a region) increases with increasing imports $\left(\mathrm{a} ; \mathrm{p}\right.$-value $\left.<0.001, \mathrm{r}^{2}=0.68\right)$ and number of regions from which a region imports at least 100 metric tonnes ( $b$; $p$-value $\left.<0.001, r^{2}=0.60\right)$. There is no significant relationship between exposure and exports ( $\mathrm{p}$-value $=0.08, \mathrm{r}^{2}=0.18$ ) or the number of regions to which a region exports ( $\mathrm{p}$-value $\left.=0.61, \mathrm{r}^{2}=0.02\right)$. Exposure is averaged across degree of shock, degree of spread and perturbed region (with no GDP effect included). 


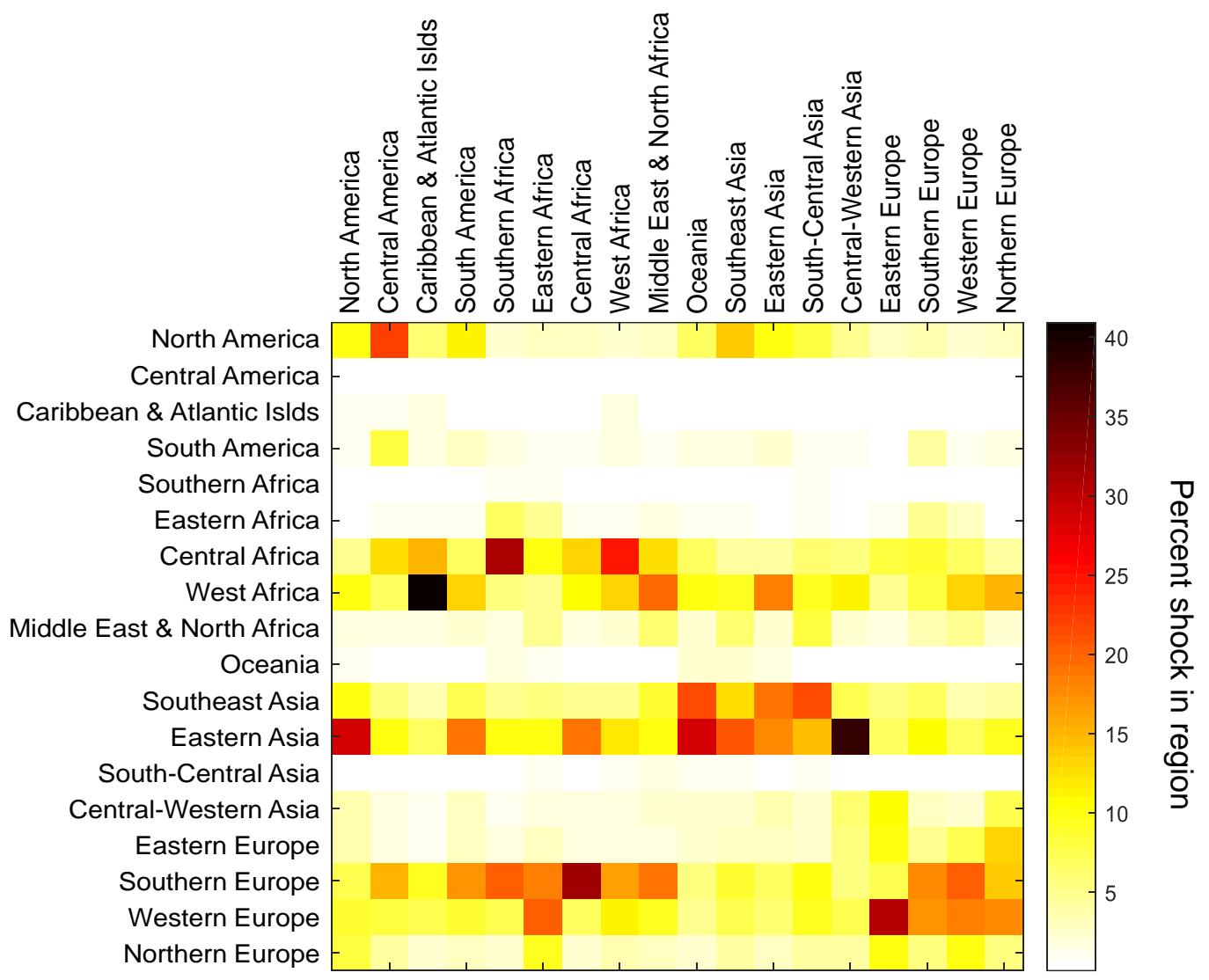

Figure 2.3: Influence of shocks initiated in each region and exposure to shocks initiated in each region. Each region's (vertical axis) exposure to a perturbation occurring in each other region (horizontal axis) is indicated by cell color, representing the percent of initial shock ending up in each region. Exposure is averaged across degree of shock and degree of spread (with no GDP effect included). 


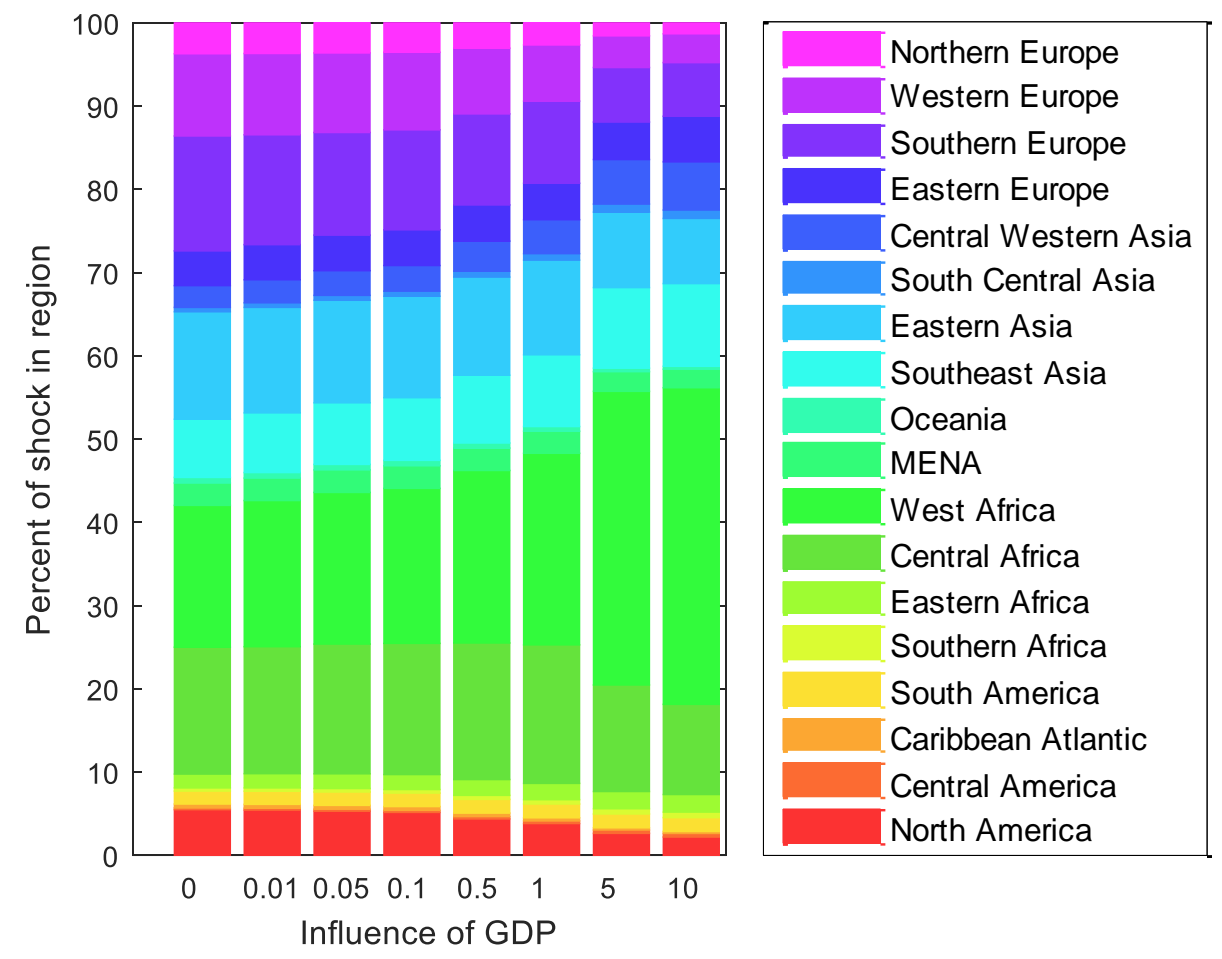

Figure 2.4: Increasing influence of GDP increases proportion of shock ending up in West Africa. Stacked bars show the average (over degree of shock, degree of spread and perturbed region) $\mathrm{p}$ of shock ending up in each region for varying influence of GDP on how the shock is distributed. As the influence of GDP increases, an increasing percent of the shock ends up in West and Southern Africa. 


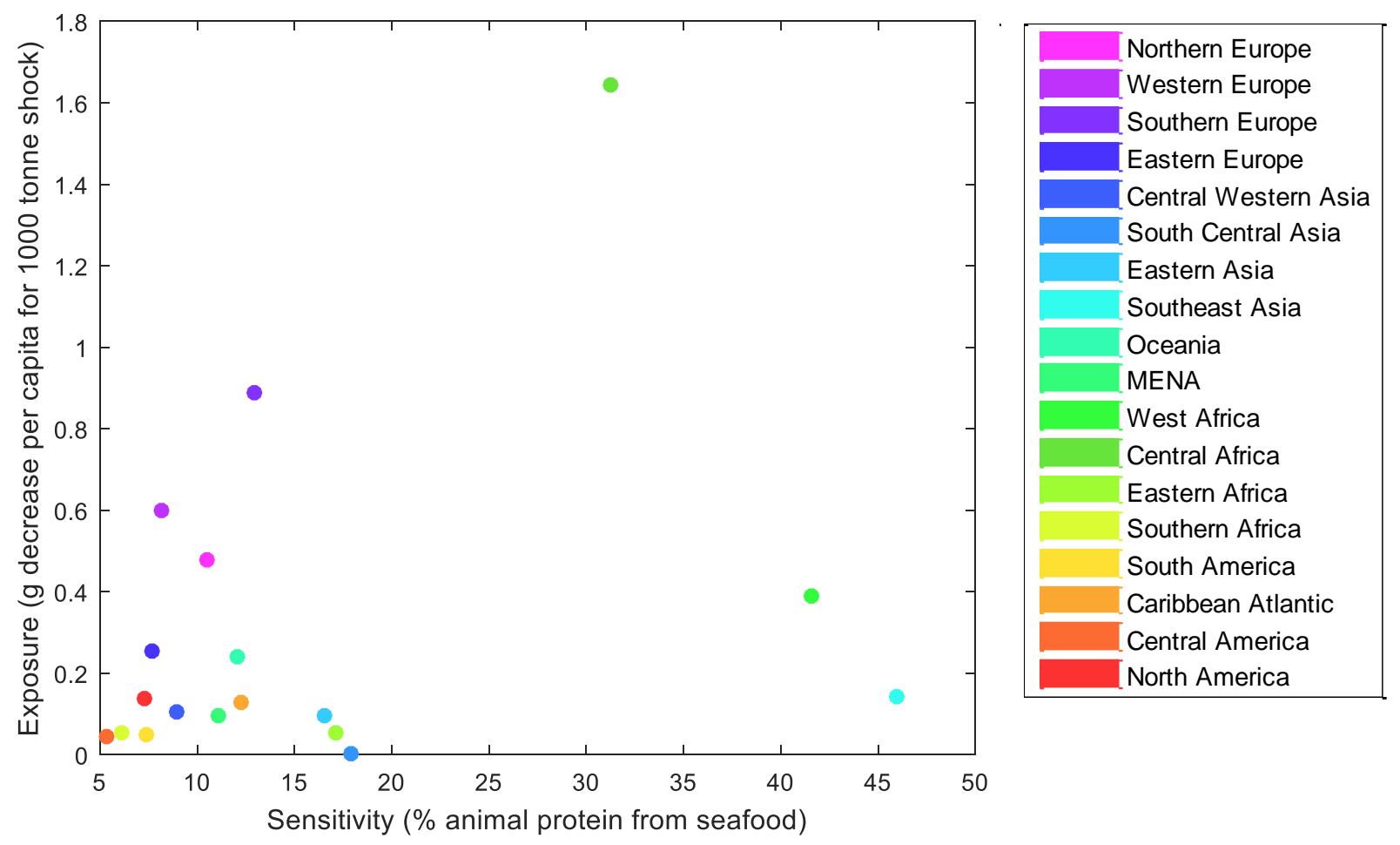

Figure 2.5: Relative vulnerabilities of the regions through comparisons of exposure and sensitivity. Average exposure for each region (g seafood decrease per capita for a 1000 tonne shock, averaged over degree of spread and perturbed region) compared to fish protein dependency (percent of animal protein from seafood). 


\title{
ChaPTer 3: PATterns Of SHOCKS TO GLOBAl Fish PRODUCTION AND TRADE
}

\begin{abstract}
Sudden disruptions, or shocks, to food production can impact access to and trade of food commodities. Historical shock events provide an opportunity to learn whether such events are occurring more frequently, whether systems differ in the shock frequency and intensity, how quickly food production recovers, and how trade and food supply are altered. Here, we focus on shocks to seafood production because this resource is globally important to nutrition, a highly traded commodity, and exposed to multiple potential shocks, including fishery collapses, natural disasters, oil spills, policy changes, and aquaculture disease outbreaks. Using a statistical shock detection approach with a complementary qualitative approach, we identify 50 shocks in aggregated national production time series and 553 in the national species time series. There is no trend in the frequency or magnitude of shocks in the aggregated production or in the magnitude of shocks in the species production, but there is an increase in the frequency of shocks in the species time series. The highest number of shocks occurred in Europe, Africa, and Asia, which also tended to have shocks of larger magnitude. Shock rates and magnitudes were similar among species groups, but shocks occurred more frequently in aquaculture systems than capture systems. Further, when shocks occur countries tend to increase imports, increase and decrease exports equally, and tend to experience decreases in supply. To illustrate the different responses to shocks, we describe four cases studies (the former USSR, Ghana, Saint Pierre and Miquelon, and Sri Lanka) which represent four different shock causes. Learning from such examples will be important to identify potential risks and opportunities to building resilience in the global food system.
\end{abstract}




\section{Introduction}

Sudden unexpected changes, or shocks, can alter the function or state of a system and when shocks occur in food systems they can impact local nutrition and trade (Scheffer 2009; Gephart et al. 2016). A food system is composed of the food production, processing, distribution, consumption, and waste management and disruptions at any stage can limit access to food (Pothukuchi and Kaufman 2000). Food systems with low resilience are limited in their ability to respond and adapt to disruptions through alternative food sources, backup distribution mechanisms, or emergency supplies, causing food shortages of varying degrees of intensity and duration. However, even when food production shortages are temporary, periods lacking essential nutrients adversely impact the health of vulnerable populations such as pregnant women, children, and the ill (Block et al. 2004). For example, the drought in the Horn of Africa in 2011 contributed to the food insecurity and malnutrition of over 11 million people, with one in three children suffering from food shortages, widespread decrease in farmer and agribusiness worker incomes, and increased unemployment (UNEP 2011). Income and asset loss and unemployment throughout the food production chain have lasting impacts for poor families which can perpetuate poverty traps (Cuny and Hill 1999).

Further, shocks to primary commodities may have distant impacts on food prices and access via propagation through the global trade network. Exposure to shock propagation has recently been explored through network models and the 2008 grain crisis provides an example of a shock spreading through the trade network (Gephart et al. 2016; Tamea et al. 2016; Bren d'Amour et al. 2016; Merchand et al. in review). The grain price spike has been attributed to increased demand for biofuels, higher oil prices, decreasing grain stocks, and the weakened US dollar (Heady 2011). Rising wheat prices led India, the second largest rice producer, to ban exports 
of non-Basmati rice in 2007, which led other rice exporting countries, including China, Vietnam, and Egypt, to introduce their own export bans shortly thereafter (Christiaensen 2009). Some major importers, including the Philippines, responded by purchasing additional rice at increasing prices. Hoarding then further drove up the global price of rice (Christiaensen 2009). By the end of the crisis, the World Bank reported over 130 million people were driven into poverty and the FAO estimated that an additional 75 million people became malnourished (Heady 2011). Cases such as this one illustrate the potential for multiple stressors to lead to crises and for those crises to propagate on large spatial scales (Homer-Dixon et al. 2015).

While droughts and the 2008 grain crisis have shed light on cases of shocks to agriculture production systems, changes in fisheries systems have tended to focus on long-term trends rather than sudden drops and resulting implications. However, the effect of shocks is relevant to seafood production since seafood is among the most highly traded food commodities and is impacted by multiple potential shocks including fishery collapses, natural disasters, oil spills, policy changes, and aquaculture disease outbreaks. Further, as the source of almost $20 \%$ of global animal protein and essential nutrients, shocks to seafood systems can have important food security implications (FAO 2014).

While shocks have been defined and identified in specific systems with known causes or based on long time series, these methods cannot be applied in general when the shock cause is unknown and long time series data is unavailable. This is particularly problematic for food production systems, including fisheries, which are exposed to multiple environmental, policy, and economic shocks. One approach to identifying shocks is to use expert or local knowledge to find events considered as shocks to a system. While this approach is valuable for studying individual systems, it is difficult to standardize the definition of a shock across systems and may be biased 
against shocks that are not widely reported on or those which occurred in distant memory. As a result, a data-driven approach can complement system knowledge to identify shocks across systems.

There are competing factors that could contribute to more or fewer shocks over time or in particular regions or systems (Table 3.1). Increasing exploitation, intensification and connectivity of aquaculture and natural or environmental disasters could contribute to more shocks while improved capture fishery management, proactive avoidance measures, or stocks collapsing prior to the study period could contribute to fewer shocks observed (Table 3.1). Other factors could contribute to either more or fewer shocks depending on the particular case, such as the increasing connectivity of the global market (which could increase pressure or provide a buffer) or increased data availability (which could allow for increased intensification or improved management). A pattern in historical shocks would identify potential vulnerabilities in the seafood production system. Further, patterns in the impact of shocks on trade and supply to inform whether and when a regional shock will have distant impacts through international trade or may impact local nutrient availability.

Here we apply a statistical shock identification approach to identify shocks in fisheries catch time series in order to answer the following questions: 1) have the frequency or intensity of shocks increased; 2) do regions or production systems (species groups, capture, or aquaculture) have more, larger or longer shocks; and 3) how are shocks divided among decreased exports, increased imports, and changes in domestic supply? We discuss four case studies in detail to illustrate the specific trade and seafood supply impacts of shocks which arise from different causes. 


\section{Methods}

Shocks can be identified through qualitative approaches based on literature or news reports and through quantitative approaches based on outliers or known system properties. For example, both heat waves and floods are defined as extremes relative to the historical distribution of events while droughts are identified by indices comparing supply and demand for soil moisture in regions (e.g. the Palmer drought index). While qualitative approaches are useful for studying individual systems, potential reporting biases, such as less reporting in some regions or over time, limit the use for making spatial or temporal comparisons. In order to avoid such a bias, we use a quantitative approach to identify shocks and then compliment this identification with a search of news, literature, and reports to match shocks with events that are potential shock causes. Such a complementary approach has previously been used to detect shocks in macroeconomic time series (Balke and Fomby1994).

We analyzed shocks in production time series from FAO FishStat for each country (FAO FishStat 2014). The "Global Commodities Production and Trade" quantity data was used for the aggregated production and trade analysis while the "Global Production by Production Source" quantity data was used for the species and production system analysis. An existing method commonly used in exploratory spatial statistics was modified to detect shocks based on deviations in the autocorrelation (Anselin 1995; Anselin 1996). More specifically, shocks were identified as outlier points, or points with high Cook's D values $(>0.35)$, in a regression of the residuals and lag-1 residuals from a lowess fit of the time series with a smoother span of 2/3 (see Figure 3.1). The threshold of 0.35 was selected by comparing the total number of shocks identified to the threshold and selecting the point where the curve became relatively flat (Appendix 3, Supplementary Figure 1). 
Shocks can be characterized by the frequency at which they occur in a system, the magnitude or intensity of the shock, and the duration or time to recovery. The frequency was defined as the interval at which a shock occurs and the magnitude was defined difference between a point and the previous 5-year average. For this analysis, only shocks representing a decrease were selected. This means the magnitude is negative for all shocks, but we display the absolute value of the magnitude in all figures. Recovery of production from a shock was defined as the point where production returned to within at least $5 \%$ of the pre-shock production level. Recovery of production does not however imply sustainable harvest. For example, a system may be operating beyond a sustainable level and reduce catch down to a sustainable level (at which point a shock would be detected) and never return to the elevated, unsustainable level (i.e. never recover). Both temporary and lasting drops in production are considered shocks in this analysis because when a shock occurs it is not generally known if or when catch will return to pre-shock levels. Consequently, some shocks appear as a point, while others appear as a step change.

Since purely data-driven approaches cannot determine the cause of a shock, we compliment the analysis with a search of the literature, reports, and news sources to identify the potential or likely cause(s) of each shock which occurred in the aggregate production time series (Figure 3.2). Shock causes were not identified for the species time series due to the large number of shocks and difficulty finding sources discussing the drops in species-specific production. Shock causes are classified as political (i.e. country breaking up, war, financial crisis, etc.), overfishing, policy change related to fisheries, fishery disease, natural disaster, or unknown. The trade and supply response was quantified based on the value of imports, exports, and supply at the shock point relative to the previous five-year average. Supply data is from FAOSTAT (2014) and represents the per capita seafood available for human consumption during a given reference period. Supply 
is calculated as the production and imports minus exports, domestic use as animal feed and waste, plus any change in stocks, divided by the population.

\section{Results and Discussion}

\section{Patterns and trends in shocks to total seafood production}

There were 50 shocks detected between 1976 and 2011 in the 130 time series of total seafood production. While regions generally experienced a similar number of total shocks, the shock rate (number of shocks divided by the number of time series) was much higher in some regions than others (Figure 3.3). For example, the shock rate in the Caribbean and Central America was two and a half times the shock rate in Africa and about twice the rate in Asia and Europe (Figure 3.3). Although the Caribbean and Central America and South America had among the highest shock rates, they also had a higher percent of cases where the production recovered to preshock levels $(80 \%)$ and the recovery times for these regions were among the lowest. This is compared to only $30 \%$ of cases returning to pre-shock levels in Europe, Africa, and the Middle East and North Africa. Shock magnitudes tend to be fairly similar across regions, but the highest mean magnitudes occur in Europe, Asia, and Africa (Figure 3.3). In general, the distributions of magnitudes and recovery times are asymmetric, such that most shocks are small and most recoveries are quick, but when they are not they are much larger or longer than the medians.

Shocks did not become more frequent or larger in the aggregated national seafood production time series (Figure 3.2). This suggests that shocks are a common feature of these production systems. Similarly, Sartori and Schiavo (2015) found no evidence for an increase in the number of shocks in agricultural systems in the past 25 years. The shocks to seafood production occurred due to a variety of identified causes, but are dominated by political factors, fishery policy changes, and overfishing, often coupled with a policy change to limit fishing pressure. No trend 
analysis within shock cause categories can be reliably conducted due to the potential bias of the points with unknown causes. The lack of trends and variety of factors supports a mixture of the hypothesized reasons to expect an increase or decrease in shocks over time (Table 3.1).

Political factors, such as the breakup of a country, war, or financial crises, were frequently identified as a potential cause of a seafood production shock. In fact, the largest shock identified, the breakup of the USSR (described in more detail below) was a political shock. However, such political disruptions occur at irregular intervals and therefore would not be expected to drive a trend over this period. We expected that overexploitation could be leading to more shocks or that improved management could be reducing shocks. While overfishing and policy measures to avoid overfishing are frequently identified as causes of the drops in production, there is not a strong trend over the period considered. Since the policy changes are typically aimed at reducing overfishing, one would expect that these systems will experience fewer shocks due to overfishing in the long run. These cases of shocks may be examples of the short term cost of improving management for long term sustainability.

Countries are likely able to anticipate or prevent shocks to varying degrees in different cases. Slow developing situations leading to shocks, such as overfishing, can be monitored and expected if action is not taken. Such slow drivers offer the possibility of statistical early warning indicators through monitoring that would allow a response or preparations prior to a shock. Policy changes which are slowly phased in or have delayed implementation dates also make the production drop expected. Anticipated decreases in seafood production may allow relevant stakeholders to prepare in advance of the shock, which would mitigate the shock's impacts. Other shock causes, such as a disease outbreak or natural disaster, are generally less predictable. This means there is less time for any management intervention or preparation. As a result, nations must 
improve the resilience of the food system by diversifying available food sources, maintaining backup distribution mechanisms, or emergency supplies, and building capital to help deal with crises in order to reduce the societal impacts of a shock in these cases.

Trends and patterns in shocks to seafood production by species group

There were 553 shocks detected between 1976 and 2011 in the 1461 species group time series. As with the aggregated data, there is no trend in the magnitude of shocks, but there is an increase of 0.65 shocks per year in the frequency (Figure 3.4). This supports the finding that shocks are a common feature of seafood production systems and provides evidence for an increase in frequency at the species-level. While the causes of these shocks in the species time series could not be identified for enough points to make comparisons, it is likely that these shocks also occur due to a variety of factors since many of these shocks align with shocks at the national level. Others did not though, including the well-known shock to the Canadian cod fishery. A shock is detected 1989 (widely attributed to overfishing), but this shock is not detected in the aggregated fishery production for Canada. This highlights the issue of scale in this analysis. Shocks detected at the national level may be of greater interest for national trade and supply impacts, but national time series may also mask production shocks in specific fisheries. This is particularly relevant for large countries with diverse fishery production.

The shock rate and magnitude is quite similar among species groups (Figure 3.5). Interestingly, when grouped by aquaculture and capture fishery time series, the shock rate tended to be higher for aquaculture than capture fisheries from the late 1980 s to the present, a period of rapid aquaculture development (Appendix 3, Supplementary Figure 2). The highest number of shocks occurred in the miscellaneous and crustacean categories while the fewest occurred in the marine white fish and carp categories. The percent of time series that recovered versus never 
recovered was similar across species groups (32-44\% recovered). Of the cases that recovered, mean recovery time was the lowest $(0.8$ years $)$ for marine white fish and the highest for miscellaneous fish (2.5 years) and crustaceans (2.4 years).

Since shocks represent sudden drops in production, the detection method does not identify long-term, more gradual reductions in fisheries, which are often of concern for the sustainability of a particular stock. Further, this method does not identify shocks in systems with high variability (the detection limit under different levels of variability is described in the Supplementary Information). In systems with high variability, large deviations are frequent and are therefore not considered shocks for this analysis. For example, although the drop in Chilean anchoveta catch during El Niño is well known, the reported catch data has high variability and a shock is not detected for the strong El Niño event in 1997-1998, despite the drop in catch that year (Appendix 3, Supplementary Figure 3). Such drops are more expected in these systems and therefore not a shock in the same sense. Nevertheless, high variability in production may still impact trade and seafood supply.

\section{Shock impacts on trade and seafood supply}

Countries were expected to respond to a shock to their production through a combination of increased imports, decreased exports, and decreased supply. In the detected shocks, imports increased in over one and a half times as many cases as it decreased, exports increased and decreased equally commonly, and supply decreased nearly twice as often as it increased (Table 3.2). The most common combinations were imports and supply decreases with export increases, increases in all three, and import increases with export and supply decreases. The impact is likely context dependent, with trends in the trade balance and the fishery or fisheries being affected 
playing a large role in how the shock impacts trade and supply. To illustrate this point, four shock cases and the impact on trade and supply are described below.

\section{Former USSR}

The shock with the largest magnitude occurred in 1992 in the former USSR countries and can be attributed to the breakup of the Soviet Union in 1991. From the 1970s up to 1991 the Soviet Union supported a large coastal and distant fishing industry with an estimated $\$ 30$ billion in subsidies (Milazzo 1998). This led to an overcapitalization of the Russian fleet and supported high levels of total catch (Figure 3.6). The subsidies also resulted in an inefficient fleet, with Soviet ships landing $1 / 5$ of the catch per ton of fishing fleet compared to the EU or Japan at the end of the Soviet Era (Kravanja et al. 1993). Financial support for the fisheries rapidly disappeared after the dissolution of the Soviet Union and the aging ships were divided among the newly independent states (Milazzo 1998). Fish catch dropped precipitously during this transition (Figure 3.6). Without the subsidies most fishing operations were no longer profitable and $80-85 \%$ of the fishing enterprises assessed were filing or near filing bankruptcy (Milazzo 1998).

Exports increased gradually during the 1980s after the USSR opened trade to socialist countries, but decreased during the early 1990s during the dissolution of the USSR (Figure 3.6). The exports rebounded by the mid-1990s and continued to increase thereafter, coinciding with the former Soviet countries opening to trade with the West. In the period immediately following the dissolution of the Soviet Union the exports as a percent of catch increased dramatically. This situation is exemplified by Estonia, where foreign trade opening within the country caused the price of fish, which had previously been depressed, grew to nearly the level of Western Europe and fish exports increased rapidly (Vetemaa et al. 2006). Further, Estonia's independence allowed access to fishing grounds that were previously tightly regulated by Soviet border controls 
(Vetemaa et al. 2006). The Estonian government passed policies aimed at increasing access to fisheries for household consumption, but high prices for fish resulted in catches being sold to traders for export (Vetemaa et al. 2006). The decreased catch in conjunction with the increased exports can explain the initial drop in per capita seafood supply in 1992 and the further decline through 1994 (Figure 3.6). The rebound in supply corresponds to the gradual increase in imports and catch. Nevertheless, the supply and catch do not return to pre-shock levels by the end of the time series (Figure 3.6). This case illustrates a large political shock with lasting impacts throughout the fishing industry. Clearly, the breakup of the USSR had impacts far beyond fishery catch, including the dramatic changes in trade policies which can help explain the increases in both imports and exports which may not otherwise be expected at a shock point.

\section{Ghana}

Ghana has historically been a major fishing nation in West Africa, with a high reliance on seafood for nutrition, employment, and the national economy (Atta-Mills et al. 2004). Ghana's productive coastal waters in the Gulf of Guinea result from the Central West African upwelling system. There is seasonal variability in the fishery's productivity due to annual upwelling cycles, while interannual variability is driven by large-scale atmospheric pressure systems in the South Atlantic and El Niño events in the tropical Pacific (Perry et al. 2011). Despite this natural variability, the year 2000 represents a shock that falls outside the normal variability of the system and over-exploitation is the most likely explanation for this drop in catch (Figure 3.6; Atta-Mills et al. 2004). By the mid-1990s landings of pelagic fish had leveled off and inshore marine resources were fully- or over-exploited (Perry et al. 2011; Atta-Mills et al. 2004). Further, catch per unit effort for demersal species declined through the 1980s and 1990s (Koranteng 2002). Total catches were maintained through the 1990s by fishing farther off shore or switching gear to target different 
or new species. Historically, Ghanaian fishermen had adapted to periods of low catch by migrating to new fishing areas in this way, but enforcement of the Economic Exclusive Zones and other policy actions by neighboring countries limited migration opportunities (Atta-Mills et al. 2004).

Despite the drop in total production in 2000, seafood exports remained relatively constant, thereby representing an increase in the percent of seafood exported (Figure 3.6). During the mid1990s when catch per unit effort was declining, imports increased and Ghana became a net importer of seafood. Now, Ghana primarily exports high value species (e.g. shrimp, tuna, cuttlefish) while importing lower value, frozen seafood (Atta-Mills et al. 2004). Around this time per capita supply of seafood began to track the pattern in imports (Figure 3.6). Although the catch and supply numbers for Ghana likely underestimate the role of subsistence fisheries (Nunoo et al. 2006), the data capture the dominant patterns in production, trade, and supply. This case illustrates historical overfishing, possibly in combination with limitations on fishing in neighboring waters, leading to a drop in production and a long-term trend of increasing imports compensating for stagnating catches.

\section{$\underline{\text { Saint Pierre and Miquelon }}$}

Saint Pierre and Miquelon are French territorial islands off the coast of Newfoundland. The islands host a small population and the economy has traditionally been based on fishing and servicing fishing vessels (The World Factbook 2016). Cod is the most important fishery for the islands and this case illustrates a situation where seafood catch is largely destined for export and the exports trace the annual catch very closely (Figure 3.6). France's fishing rights in the waters off Newfoundland date back to the Treaty of Utrecht of 1713, but became a source of dispute in the 1977 when both France and Canada extended their fishing zones to 200 nautical miles from their coasts (McDorman 1990). This resulted in overlapping claims to waters with productive 
fisheries and potential hydrocarbon resources (McDorman 1990). A 1972 agreement allowing France access to 17,500 tons of catch kept the dispute at bay. But, the territorial struggle escalated and peaked in 1987-1988 when Canada claimed France was exceeding its fishing quota, denied the agreement renewal, and blocked French vessels from ports and the fishing grounds (Burns 1988). Canada then arrested the crew of a vessel registered in Saint Pierre and Miquelon and France retaliated by recalling the Canadian ambassador to France and denying Canadian citizens entry at Parisian airports (McDorman 1990). The 1988 dispute is identified as the first shock point in Figure 3.6. Canada and France reached an agreement through mediation in 1989 and fish catch in Saint Pierre and Miquelon rebounded (McDorman 1990; Figure 3.6). However, in 1993, a much larger shock occurred when the cod stock was near commercial extinction and the entire fishery was closed to rebuild stocks (Hutchings and Myers 1995). Immediately following the reductions in catch, seafood imports jumped up, before catch increased to a moderate level compared to the pre-shock conditions (Figure 3.6). FAO seafood supply information is unavailable for these islands, but the collapse and closure of the cod fishery severely impacted the livelihoods of the people in the region (Milich 1999). This case illustrates a political dispute and a policy change, both with a back drop of overfishing. Since this was an export-oriented fishery, drops in production were mirrored by drops in exports.

\section{$\underline{\text { Sri Lanka }}$}

Sri Lankan fisheries employed around 163,000 people in the fisheries sector, with subsistence fishing providing a livelihood for many unemployed people prior to the tsunami in December of 2004 (Ministry of Fisheries and Aquatic Resources 2003). Sri Lanka's fisheries are known to have been stressed prior to 2005 , but the tsunami and resulting devastation was directly associated with the 2005 shock to production. Ten of the twelve main fishing harbors were severely 
damaged, along with 65 percent of the fishing fleet (De Silva and Yamoa 2007). Damage to fishing craft and gear was particularly severe because the event occurred on a holiday when the boats were inshore and received the full impact of the tsunami (Stirrat 2006). There was also significant damage to the post-harvest sector, including markets and retail stalls, as well as concerns about damaged waste water systems leaking into fishing grounds (De Silva and Yamao 2007). Immediately following the disaster, a vast range of relief organizations became active in Sri Lanka. After natural disasters, there is an incentive for NGOs to spend money on visible aid, including distributing new fishing gear (Stirrat 2006). Such actions resulted in the number of boats in some areas of Sri Lanka to exceed the number of boats prior to the tsunami (FAO 2007). This, along with the new boats having higher catching power than the old boats, can likely explain the sharp jump in seafood production the year following the storm (FAO 2007; Figure 3.6).

The majority of seafood produced in Sri Lanka is through small-scale fisheries and is destined for domestic consumption. This is reflected in Figure 3.6 where the patterns of per capita supply mirror the patterns of seafood production. Sri Lanka is highly dependent on seafood, with 52 percent of animal protein derived from seafood and much higher levels of dependency in coastal fishing communities (De Silva and Yamoa 2007). Imported dry and canned fish flooded the retail markets immediately after the tsunami, but the average prices were substantially higher than the average prices for local fish (Subasinghe 2005). Overall there was not an increase in the imports for 2005 but there was a substantial drop in per capita seafood supply at the shock point (Figure 3.6). This case illustrates a shock from a natural disaster and the impacts this type of shock can have throughout the seafood system. It also illustrates a case where changes in trade fail to compensate for the drop in production, resulting in a temporary decrease in local seafood supply. Impacts beyond national seafood supply and trade balance 
Shocks to seafood production extend beyond the per capita seafood supply and national trade balance. Capture fisheries employed 58.3 million people in 2012 , with $37 \%$ of those people employed full time (FAO 2014). Employment in the fishery sector has grown at a faster rate than the world population and traditional agriculture sector (FAO 2014). A majority of people employed in fisheries live in Asia and Africa and the FAO estimates that the fisheries sector assures the livelihoods of 10-12 percent of the world's population (FAO 2014). These figures may underestimate the number of people in the developing world employed through subsistence fishing (Teh an Sumaila 2013). As a result, shocks can impact GDP and unemployment levels at the national scale and can have lasting impacts on families' finances for those relying on fisheries for income.

Declines in fishery catch can cause shifts in employment, crime, and sources of food. For example, negative economic shocks to fisheries are correlated with an increase in piracy and declining fish harvests have been linked to increases in human trafficking when fishers attempt to minimize production costs (Flückiger and Ludwig 2014; Brashares et al. 2014). Declines in seafood catch have also been linked to increases in hunting in nature preserves and the sale of bushmeat in local markets in West Africa (Brashares et al. 2004). Thus, fishery shocks can reach beyond trade and nutrition, impacting human trafficking, organized crime, and biodiversity conservation.

While this study focused on the trade balance impacts at the national scale, changes in imports and exports imply alterations of the trade partners' trade balance. A series of recent studies have explored the distant impacts of shocks to primary commodities in the global trade network in the 2008 grain crisis and network models (Puma et al. 2015; Gephart et al. 2016; Tamea et al. 2016; Bren d'Amour et al. 2016; Merchand et al. in review). These studies have found import- 
dependent countries, countries with low production diversity, and regions with low willingness to pay as being more vulnerable to external shocks in the network. Merchand et al. (in review) found that national reserves dampen the propagation of a shock. Since seafood is not held in reserves in the way grains are, the propagation of a shock could be more far-reaching. Evaluating the distant impacts of shocks to seafood production in historical examples, such as those identified here, is an important next step in understanding how shocks may alter the global trade network.

\section{Conclusion}

Historical shocks to seafood production have occurred due to a variety, and often multiple simultaneous, causes and the resulting impacts are highly context specific. As a result, we did not find evidence of strong trends or patterns in shocks over the past 30 years, but instead found such shocks to be a common feature of these systems. Further, while the trade balance and food supply response to shocks is context specific, there is a tendency for the imports to increase while the exports and supply decrease. The complementary quantitative and qualitative methods employed here provide a systematic approach to look back in time to identify shocks and evaluate their impacts in an increasingly globalized system. Learning from such examples will be important in order to identify potential risks and opportunities to building resilience in the global food system. 


\section{References}

Anselin, L (1995) Local indicators of spatial association-LISA. Geographical Analysis, 27(2): 93-115.

Anselin, L (1996) The Moran scatterplot as an ESDA tool to assess local instability in spatial association. In Spatial analytical perspectives on GIS, pp. 111-125.

Atta-Mills, J, J Alder and UR Sumaila (2004) The decline of a regional fishing nation: The case of Ghana and West Africa. Natural Resources Forum, 28: 13-21.

Balke, NS and TB Fomby (1994) Large shocks, small shocks, and economic fluctuations: Outliers in macroeconomic time series. Journal of Applied Econometrics, 9(2): 181-200.

Block SA, et al. (2004) Macro shocks and micro outcomes: Child nutrition during Indonesia's crisis. Economics and Human Biology 2:21-44.

Brashares, JS, B Abrahms, KJ Fiorella, CD Golden, CE Hojnowski, RA Marsh, DJ McCauley, TA. Nuñez, K Seto and L Withey (2014) Wildlife decline and social conflict. Science, Vol. 345(6195): 376-378.

Brashares, JS, P Arcese, MK Sam, PB Coppolillo, ARE Sinclair and A Balmford (2004) Bushmeat hunting, wildlife declines, and fish supply in West Africa. Science, 306(5699): 1180-1183.

Bren d'Amour, C, L Wenz, M Kalkuhl, JC Steckel1 and F Creutzig (2016) Teleconnected food supply shocks. Environmental Research Letters, 11: 035007.

Burns, JF (1988) Canada-France Fishing Dispute Runs Deep. The New York Times, 8 May 1988.

Christiaensen, L. (2009) Revisiting the global food architecture: Lessons from the 2008 food crisis, World Institute for Development Economics Research, Discussion Paper No. 2009/04.

Cuny FC, Hill RB (1999) Famine, Conflict, and Response: A basic guide. Kumarian Press, West Hartford CT.

De Silva, DAM and M Yamao (2007) Effects of the tsunami on fisheries and coastal livelihood: A case study of tsunami-ravaged southern Sri Lanka. Disasters, 31(4): 386-404.

Flückiger, M and M Ludwig (2014) Economic shocks in the fisheries sector and maritime piracy. Journal of Development Economics, 114: 107-125.

Food and Agriculture Organization of the United Nations (FAO) Regional Office for Asia and the Pacific (2007) An overview of the impact of the tsunami on selected coastal fisheries resources in Sri Lanka and Indonesia, Bangkok. 
Food and Agriculture Organization of the United Nations (FAO) (2014) The State of World Fisheries and Aquaculture 2014. Rome, 223 pp.

Food and Agriculture Organization (2014) FAOSTAT database, Available at: http://faostat3.fao.org/faostat-gateway/go/to/home/E

Food and Agriculture Organization, FishStat database (2014) Available at: http://www.fao.org/fishery/topic/166235/en.

Gephart, JA, E Rovenskaya, U Dieckmann, ML Pace and Å Brännström (2016) Vulnerability to shocks in the global seafood trade network. Environmental Research Letters, 11(3): 035008 .

Headey, D (2011) Rethinking the global food crisis: the role of trade shocks. Food Policy 36, 136146.

Homer-Dixon, T., B. Walker, R. Biggs, A.-S. Crépin, C. Folke, E. F. Lambin, G. D. Peterson, J. Rockström, M. Scheffer, W. Steffen, and M. Troell. 2015. Synchronous failure: the emerging causal architecture of global crisis. Ecology and Society 20(3): 6.

Hutchings, JA and RA Myers (1995) The biological collapse of Atlantic cod off Newfoundland and Labrador: An exploration of historical changes in exploitation, harvesting technology, and management. In The North Atlantic fisheries: successes, failures, and challenges. Edited by R. Arnason and L. Felt. Institute of Island Studies, University of Prince Edward Island, Charlottetown, P.E.I. pp. 37-93.

Kravanja, Milan and Ellen Shapiro. Tlie Baltic States, The Commonwealth of Independent States, and Eastern Europe (fishing fleets). Published in: "World Fishing Fleets: An Analysis of Distant-water Fleet Operations. Past-Present-Future. Volume V." Prepared by the Office of International Affairs, National Marine Fisheries Service, NOAA, U.S. Department of Commerce. Silver Spring, Maryland, November 1993.

Koranteng, K.A. (2002) Status of demersal fishery resources on the inner continental shelf off Ghana. In: The Gulf of Guinea Large Marine Ecosystem (eds J.M. McGlade, P. Cury, K.A. Koranteng and N.J. Hardman- Mountford). Elsevier Science, Amsterdam, pp. 261- 274.

Leitão, F, V Baptista, K Erzini, D Iritani and D Zeller (2014) Reconstruction of mainland Portugal fisheries catches 1950-2010. The University of British Columbia Fisheries Centre, Working Paper Series, Working Paper \#2014-08.

Marchand, P, J Carr, J Dell'Angelo, M Fader, JA Gephart, M Kummu, N Magliocca, M Porkka, M Puma, Z Ratajczak, MC Rulli, DA Seekell, S Suweis, A Tavoni and P D'Odorico (In 
Review) Reserves and trade jointly determine exposure to food supply shocks. Environmental Research Letters.

McDorman, TL (1990) The Canada-France Maritime Boundary Case: Drawing a Line Around St. Pierre and Miquelon. The American Journal of International Law, 84(1): 157-189.

Milazzo, M (1998). Subsidies in World Fisheries: A Reexamination. World Bank technical paper; no. WTP 406. Fisheries series. Washington, D.C.: The World Bank.

Milich, L (1999) Resource mismanagement versus sustainable livelihoods: The collapse of the Newfoundland cod fishery. Society and Natural Resources, 12: 625-642.

Ministry of Fisheries and Aquatic Resources (2003) Annual Report. Ministry of Fisheries and Aquatic Resources, Colombo.

Nunoo, FKE, B Asiedu, K Amador, D Belhabib and D Pauly (2006) Reconstruction of marine fisheries catches for Ghana, 1950-2010. The University of British Columbia Fisheries Centre Working Paper Series, Working Paper \#2014 - 13.

Perry, RI and UR Sumaila (2007) Marine ecosystem variability and human community responses: The example of Ghana, West Africa. Marine Policy, 31:125-134.

Pothukuchi, K and JL Kaufman (2000) The food system. Journal of the American Planning Association, 66(2): 113-124.

Puma, MJ, S Bose, S Young Chon and BI Cook (2015) Assessing the evolving fragility of the global food system. Environmental Research Letters, 10, 24007 , http://dx.doi.org/10.1088/1748-9326/10/2/024007.

Sartori, M and S Schiavo (2015) Connected we stand: A network perspective on trade and global food security. Food Policy, 57: 114-127.

Scheffer, M, J Bascompte, WA Brock, V Brovkin, SR Carpenter, V Dakos, HHeld, EH Van Nes, M Rietkerk and G Sugihara (2009) Early-warning signals for critical transitions. Nature, 461(7260): 53-59.

Stirrat, J (2006) Competitive humanitarianism. Anthropology Today, 22(5): 11-16.

Subasinghe, S. (2005) Sri Lanka: Assessment of rehabilitation and re-construction needs in the tsunami affected post-harvest fisheries sector. FAO, Rome

Tamea, S., F. Laio, and L. Ridolfi. Global effects of local food-production crises: a virtual water perspective. Scientific Reports, In Press. 
Teh, LCL and UR Sumaila (2013) Contribution of marine fisheries to worldwide employment. Fish and Fisheries, 14: 77-88.

UNEP (2011) Drought in the Horn of Africa: challenges, opportunities and responses. African Ministerial Conference on the Environment, Bamako, 13-14 September 2011.

Vetemaa, M, R Eschbaum and T Saat (2006) The transition from the Soviet system to a market economy as a cause of instability in the Estonian coastal fisheries sector. Marine Policy, 30: $635-640$.

The World Factbook: Saint Pierre and Miquelon, Washington, DC: Central Intelligence Agency, Updated February 2016. https://www.cia.gov/library/publications/the-worldfactbook/index.htm (Accessed 17 February 2016). 
Table 3.1: Possible reasons to expect either an increase or decrease in the frequency or intensity of shocks in fisheries time series.

\begin{tabular}{|l|l|}
\hline \multicolumn{1}{|c|}{ Reasons for more shocks } & \multicolumn{1}{c|}{ Reasons for fewer shocks } \\
\hline Increasing exploitation & Improved capture fishery management \\
\hline $\begin{array}{l}\text { Increasing intensification and connectivity of } \\
\text { aquaculture }\end{array}$ & Proactive avoidance measures \\
\hline Increasing natural or environmental disasters & Stocks already collapsed \\
\hline $\begin{array}{l}\text { Increasing connectivity of the global market } \\
\text { Increased data connection and availability }\end{array}$ & $\begin{array}{l}\text { Increasing connectivity of the global market } \\
\text { Increased data connection and availability }\end{array}$ \\
\hline
\end{tabular}


Table 3.2: Frequency of combinations of increases (+), decreases (-), and no change (o) in imports, exports, and supply at a shock point and total increases, decreases, and no change observed for imports, exports, and supply.

\begin{tabular}{|c|c|c|c|}
\hline Frequency & Imports & Exports & Supply \\
\hline 10 & - & + & - \\
\hline 9 & + & + & + \\
\hline 7 & + & - & - \\
\hline 5 & + & - & + \\
\hline 5 & - & - & - \\
\hline 4 & + & + & - \\
\hline 4 & + & - & 0 \\
\hline 2 & - & - & 0 \\
\hline 1 & - & + & + \\
\hline 1 & - & - & + \\
\hline 1 & + & + & 0 \\
\hline 1 & 0 & - & - \\
\hline $\begin{array}{c}\text { Total } \\
\text { Increases }\end{array}$ & 30 & 25 & 16 \\
\hline $\begin{array}{c}\text { Total No } \\
\text { Changes }\end{array}$ & 1 & 0 & 7 \\
\hline $\begin{array}{c}\text { Total } \\
\text { Decreases }\end{array}$ & 19 & 25 & 27 \\
\hline
\end{tabular}



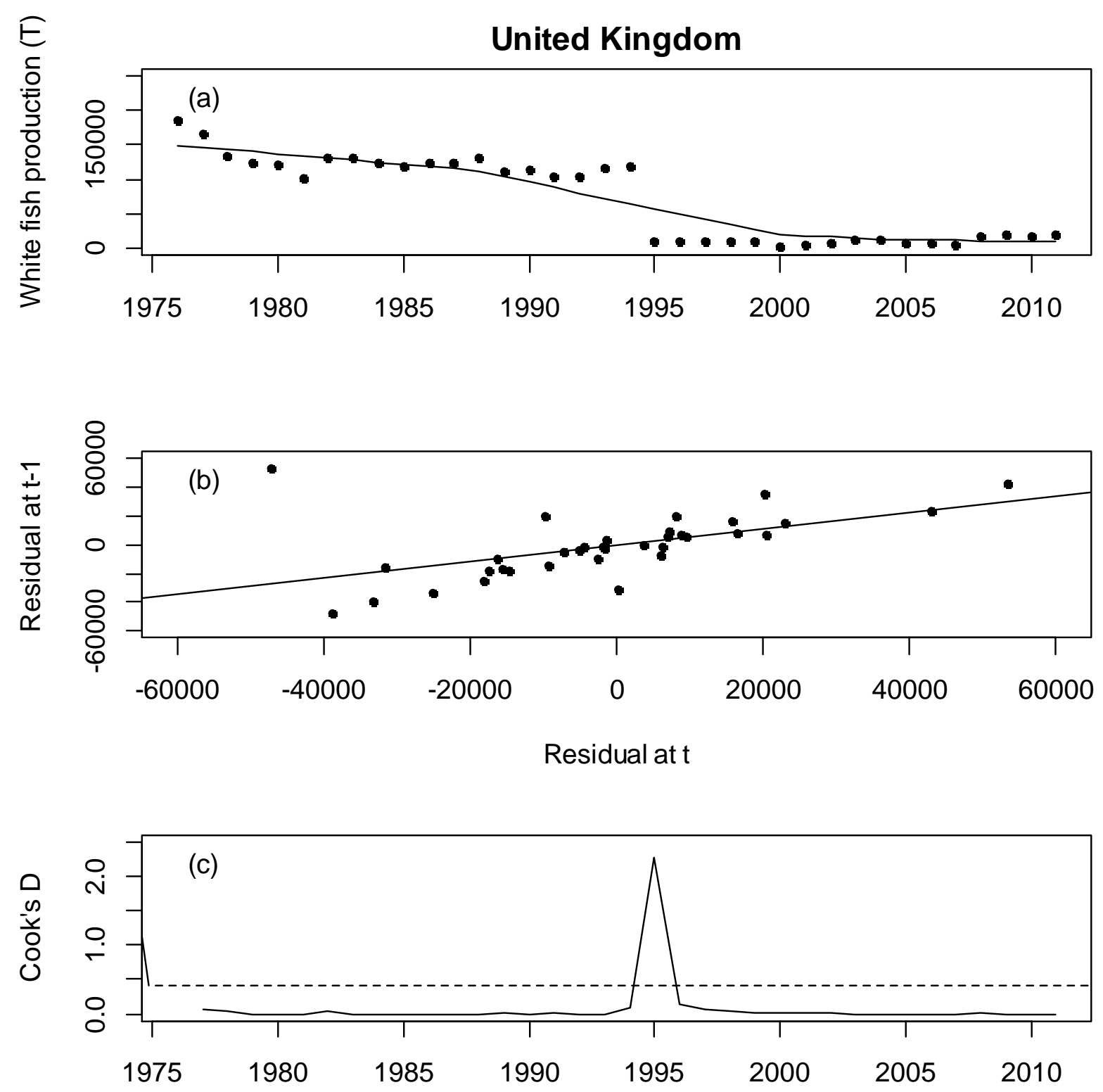

Figure 3.1: Steps identifying shocks in time series. (a) A lowess regression was fit to the time series data; (b) residuals were plotted against the time-lagged residuals; (c) Cook's D was used to identify extreme point in the regression of residuals versus time-lagged residuals. Points with Cook's D greater than 0.4 were identified as shocks. 


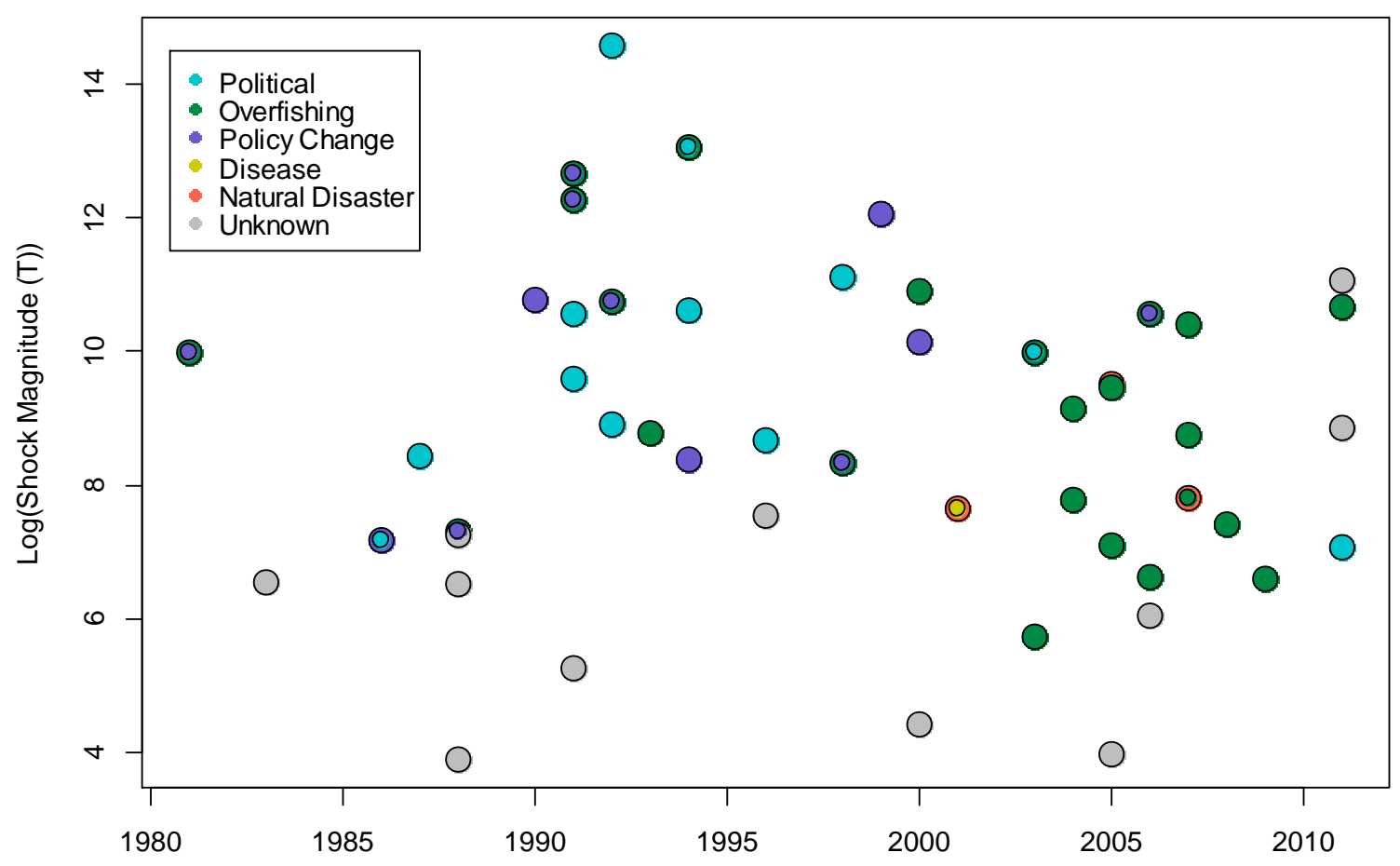

Figure 3.2: Shock magnitude for each year in total fisheries production time series for each country. Points are colored by shock cause. There is no significant trend in shock magnitude $\left(p=0.63, r^{2}<0.001\right)$ or number of shocks $\left(p=0.31, r^{2}=0.005\right)$. Points are colored according to the identified shock cause. 

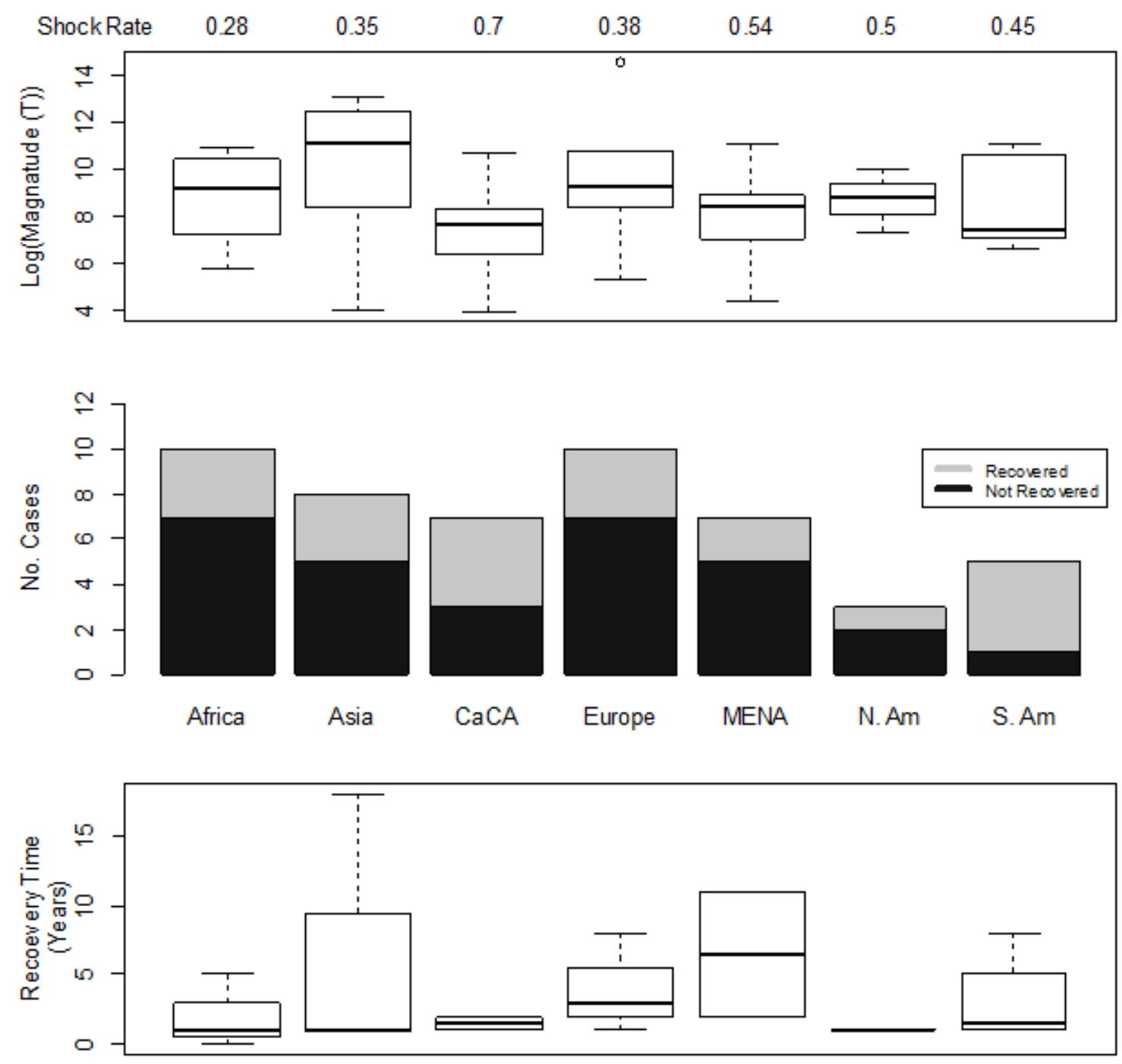

Figure 3.3: Shock rate (number of shocks divided by the number of time series in the region), magnitude, number of recovered and not recovered cases, and recovery time for by region for shocks identified in the 130 aggregated seafood production time series. 


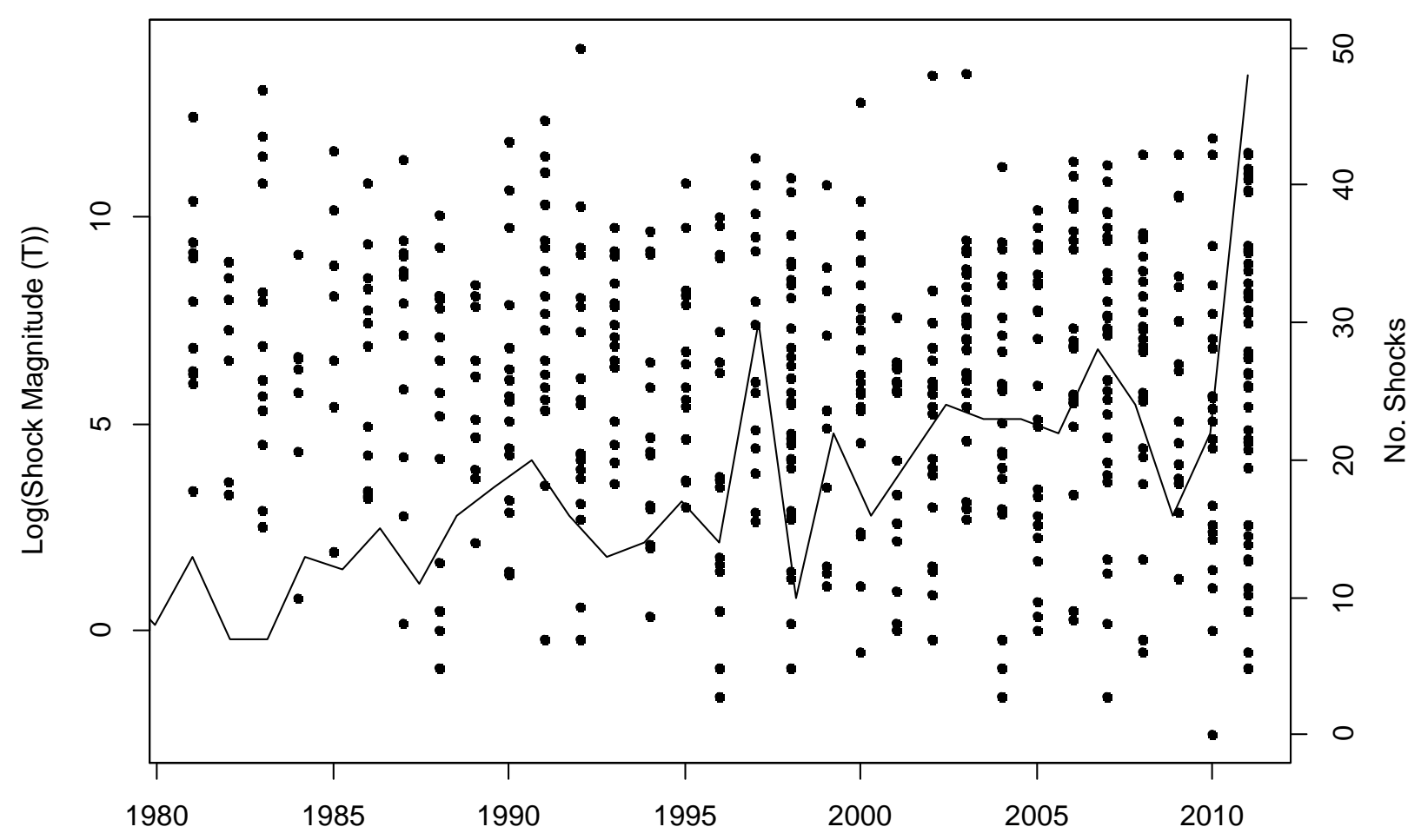

Figure 3.4: Shock magnitude (left axis; dots) and number of shocks (right axis, solid line) for each year in species group fisheries production time series for each country. There is no significant trend in shock magnitude $\left(\mathrm{p}=0.18, \mathrm{r}^{2}=0.002\right.$ ), but is a positive trend in the number of shocks (estimate $=0.65$ shocks/year, $\mathrm{p}<0.001, \mathrm{r}^{2}=0.51$ ). 

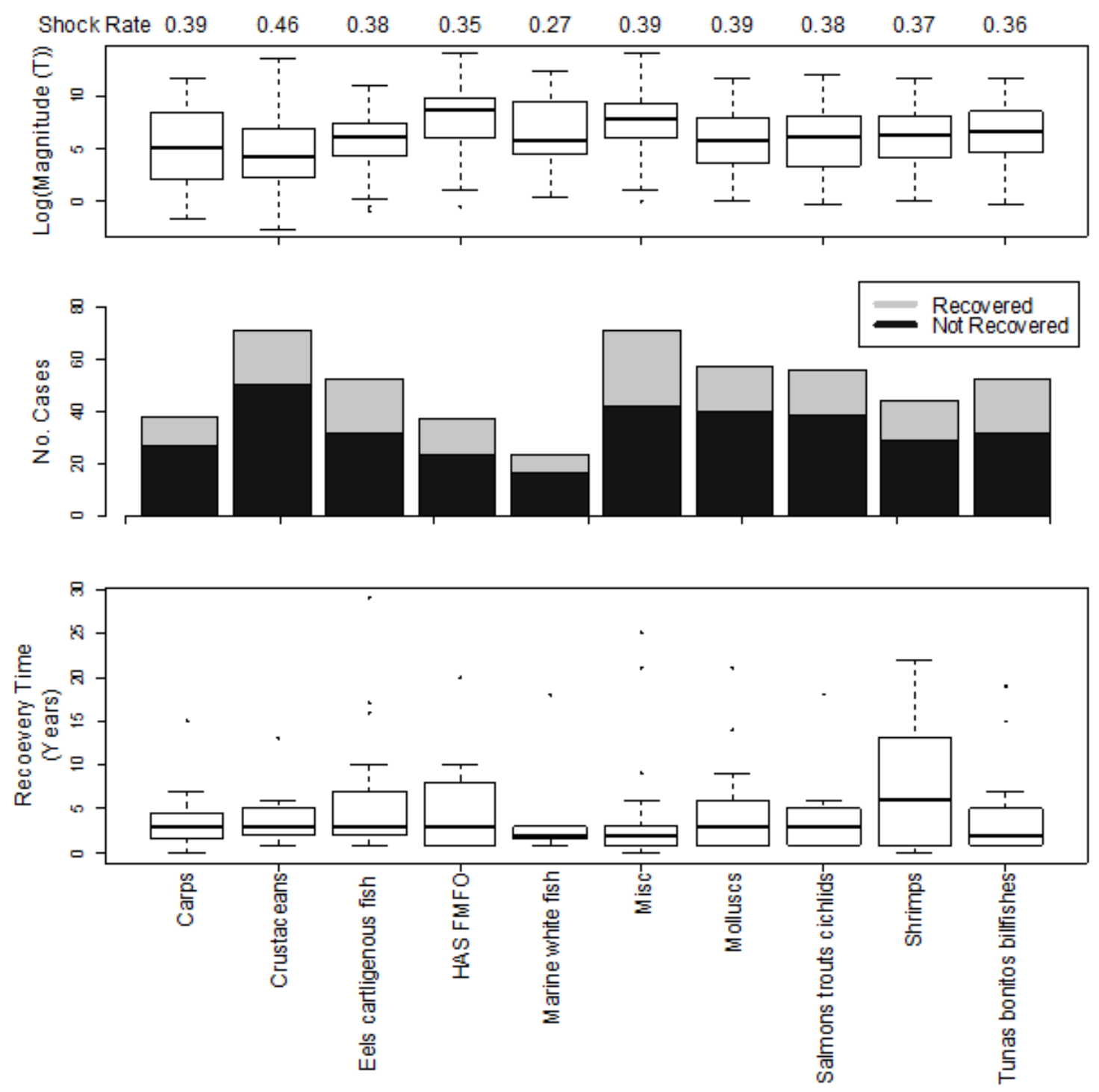

Figure 3.5: Shock rate (number of shocks divided by the number of time series in the species group), magnitude, number of recovered and not recovered cases, and recovery time for by species group for shocks identified in the species production time series. 

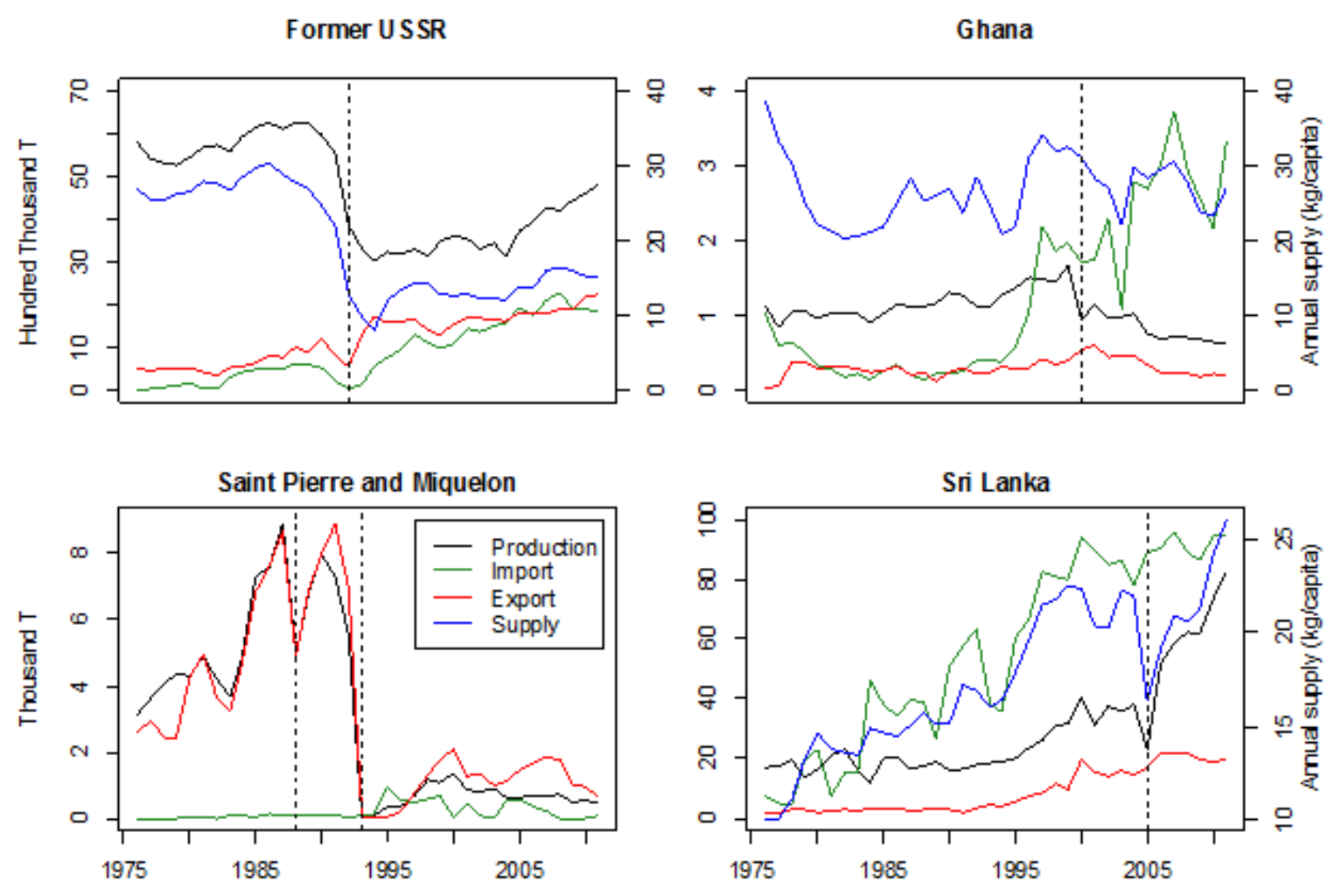

Figure 3.6: Time series of production (black), imports (green), exports (red), and per capita supply (blue; right axis scale) for the former USSR, Ghana, Saint Pierre and Miquelon, and Sri Lanka. 


\title{
CHAPTER 4: FRESHWATER SAVINGS FROM MARINE PROTEIN CONSUMPTION $^{3}$
}

\begin{abstract}
Marine fisheries provide an essential source of protein for many people around the world. Unlike alternative terrestrial sources of protein, marine fish production requires little to no freshwater inputs. Consuming marine fish protein instead of terrestrial protein therefore represents a freshwater savings (equivalent to an avoided water cost) and contributes to a low water footprint diet. These water savings are realized by the producers of alternative protein sources, rather than the consumers of marine protein. This study quantifies freshwater savings from marine fish consumption around the world by estimating the water footprint of replacing marine fish with terrestrial protein based on current consumption patterns. An estimated $7,600 \mathrm{~km}^{3} \mathrm{y}^{-1}$ of water is used for human food production. Replacing marine protein with terrestrial protein would require an additional $350 \mathrm{~km}^{3} \mathrm{y}^{-1}$ of water, meaning that marine protein provides a current water savings of $4.6 \%$. The importance of these freshwater savings is highly uneven around the globe, with savings ranging from as little as 0 to as much as $50 \%$. The largest savings as a percent of current water footprints occur in Asia, Oceania, and several coastal African nations. The greatest national water savings from marine fish protein occur in Southeast Asia and the United States. As the human population increases, future water savings from marine fish consumption will be increasingly important to food and water security and depends on sustainable harvest of capture fisheries and low water footprint growth of marine aquaculture.
\end{abstract}

\footnotetext{
${ }^{3}$ Gephart, JA, ML Pace and P D’Odorico (2014) Freshwater savings from marine protein consumption. Environmental Research Letters, 9(1): 014005.
} 


\section{Introduction}

With a current human population greater than 7 billion and growing toward 9 to 10 billion by 2050, many resource analysts have become concerned about meeting basic human needs, including access to freshwater (UNEP 2012). Over the last century, water use has grown at more than twice the rate of population increase, raising the possibility of insufficient water supply, especially in areas already experiencing water shortages (World Water Assessment Programme 2012). Over $80 \%$ of the water currently used by humans is allocated to food production (Carr et al. 2012). Marine fisheries however require little to no freshwater inputs, and therefore provide one of the most water-efficient ways of supporting the human diet.

The amount of water required to produce a unit of a good is the water footprint (Hoekstra and Chapagain 2007). The calculation of water footprints includes surface and groundwater (blue water) use, soil water (green water) use, and water required to dilute freshwater pollution to meet water quality standards (grey water) (Hoekstra et al. 2011). Water footprints are large for many terrestrial protein sources such as: chicken $(4325 \mathrm{~L} / \mathrm{kg})$, mutton/goat meat (8763 L/kg), nuts $(9063$ L/kg), and bovine meat (15415 L/kg) (Mekonnen and Hoekstra 2010).

Marine capture fisheries and aquaculture however generally do not require freshwater inputs; so despite living in water, marine fish have little to no consumptive water requirements (Hoekstra 2003). Consequently, marine protein has approximately no water footprint $(\sim 0 \mathrm{~L} / \mathrm{kg})$. As a result, replacing marine protein with terrestrial protein would result in increases in individual and national water footprints. The water cost of replacing marine protein with terrestrial protein can alternatively be viewed as a current water savings. These water savings are realized by the producers of alternative terrestrial protein sources rather than the consumers of marine protein. A country's water savings can therefore either be realized within the country itself (a lower internal 
water footprint) or through a lower water footprint of imported food (a lower external water footprint). In this second case, the physical water savings are realized in the producing country (Hoekstra et al. 2011). While only the internal water footprint is relevant to a country's domestic water resources, increasing reliance on other countries' water resources through trade may be politically undesirable or economically unfeasible (Fader et al. 2013, Seekell et al. 2011) and is therefore relevant to a country's food security.

The low water footprint of marine fisheries and aquaculture makes marine protein a fundamental source of protein for a low water footprint diet, which is especially important for water stressed regions (Duarte et al. 2009). In addition to providing water savings, fish are essential to the nutrition and food security of many impoverished countries (Kent 2003). For example, fish provide the highest percent of animal calories and protein intake in Africa relative to other regions of the world (Tacon and Metian 2009). Apart from African nations, many island nations and countries in Asia and Oceania also rely on fish for much of their protein (FAO 2009). Since many of these same regions are water stressed (WWAP 2012), water savings from marine fish consumption may be important to both domestic food and water supplies.

Continuing current water savings from marine fish consumption depends on future human food preferences, human population growth, the future state of global fisheries, and the development of sustainable aquaculture. Since food is inextricably linked to the water required to produce it, it is important to understand the tradeoffs between water resources and different food sources. Here, we translate marine protein consumption into a current "water savings" by computing the water costs of replacing marine protein with terrestrial protein using a water footprint framework. 


\section{Methods}

Current water savings from marine protein consumption is examined by calculating the water footprint (L/capita) of replacing marine protein with terrestrial protein in each country. The water footprint of marine capture and marine aquaculture fisheries was taken to be zero, as the freshwater inputs to these systems are considered to be negligible (Verdegem et al. 2006). Freshwater capture and freshwater aquaculture protein consumption was excluded from the analysis because freshwater aquaculture requires freshwater inputs ranging from very low to very high values depending on the species and production system (Boyd et al. 2007). As a result, there is not a reliable estimate for the water footprint of freshwater protein that could be used in this analysis. Approximately 35\% of the aquatic protein comes from freshwater sources (FAO 2012), which means there are many areas where freshwater protein is important and may provide water savings that unfortunately cannot be included in this analysis, notably in the countries bordering the African Rift Valley Lakes and in China.

To calculate the water savings from marine protein, the water footprint of an average gram of terrestrial protein was computed for each country and multiplied by the grams of marine protein consumed in each country. The sources of protein that would be used to replace fish protein depend on economic development, urbanization, regional soil and climate conditions, patterns of global food trade, and cultural norms (York and Gossard 2004). While this makes substitution sources for marine protein difficult to predict, reasonable estimates were derived from current food consumption patterns in each country. A range of estimates was generated by computing the water footprint of an average gram of protein based on all substitute sources and separately using only animal protein sources. 
Current consumption rates for marine protein and over 60 potential substitute sources were obtained for the most recent data year (2009) from the Food and Agricultural Organization's (FAO) food balance sheets (FAOSTAT 2013). The substitutes were grouped into the 15 food categories used by Mekonnen and Hoekstra (2010). Sugar, oil, and butter categories were removed due to the small protein contribution of these foods. The consumption rates for the remaining 12 categories (Table 4.1) were used to calculate the proportion of total protein derived from each category. Water footprints per gram of protein for each food category were obtained from Mekonnen and Hoekstra (2010).

The amount of water required to replace a gram of marine protein varies based on the combination of terrestrial protein substitutes (Table 4.1). The water footprint for a gram of terrestrial protein using all food categories is lower than the footprint using only animal product categories for nearly all countries. Water footprints for the two substitute groups in each country were each multiplied by current fish protein consumption rates to give a range of daily per capita increase in water footprints when fish protein is replaced with terrestrial protein. These values were then compared to current water footprints using the WaterStat database (Mekonnen and Hoekstra 2011) to give percent water footprint increases (Table 4.2).

As an indicator of water availability, the United Nation's water scarcity index was compared to each country's total renewable water resources per capita (AQUASTAT, FAO 2013). Total renewable resources here means total renewable surface water plus the total renewable groundwater, minus the overlap between the surface and groundwater, and this measure corresponds to the annual theoretical maximum amount of water actually available to a country at a given moment (FAO 2013). This measurement of renewable water resources represents available blue water only. According to the UN index, countries with annual water availabilities: less than 
$1000 \mathrm{~m}^{3} / \mathrm{capita}$ are water scarce, less than $1700 \mathrm{~m}^{3} / \mathrm{capita}$ are water stressed, less than 2500 $\mathrm{m}^{3} / \mathrm{capita}$ are water vulnerable, and greater than $2500 \mathrm{~m}^{3} /$ capita are water sufficient (World Water Assessment Programme 2012). This metric is used at the country-level to correspond with the FAO food consumption data, and it therefore does not account for water scarce regions within countries. Additionally, the water availability index does not account for the seasonality of rain in some countries, where water scarcity may occur during part of the year even if annual precipitation is sufficient.

Data on each country's agricultural land was obtained from FAOSTAT as an indicator for land availability and access to green water. FAOSTAT defines agricultural land as the sum of land under temporary agricultural crops, temporary meadows for mowing or pasture, land under market and kitchen gardens, land temporarily fallow, land under permanent cultivation, and permanent meadows and pastures. A land scarcity was considered where there was less than 0.1 ha per capita based on the results of Cassidy et al. 2013. While water scarcity can be better evaluated by including measurements of both blue and green water availability (Rockstrom et al. 2009), data on green water availability was not available for this study. So although agricultural land does not provide a direct measurement of green water availability, which requires an assessment of factors including precipitation and soil type, it does indicate a country's ability to access green water through agricultural lands. In some countries, additional green water can be accessed by converting natural ecosystems into agricultural land (Ridoutt and Pfster 2010), but this land was not included in this analysis. Data on renewable water resources and agricultural land together indicates which countries would likely be able to replace marine protein with terrestrial protein domestically. Since it cannot be predicted from which countries a given country would import alternative terrestrial protein, this analysis cannot speak to the impacts of replacing fish protein in a given country on 
the water securities of the countries from which it imports. It should be recognized though that a product with a large water footprint is not necessarily environmentally damaging when it is produced in a region with little water stress (Ridoutt and Pfister 2010). We do note though that increasing reliance on food imports and increasing external water footprints may not be politically or economically feasible for some countries (Fader et al. 2013, Seekell et al. 2011). By considering these factors of renewable water resources and agricultural land we assessed where fish protein is most important to national food and water securities.

\section{Results and Discussion}

Marine foods provide an essential low water footprint source of protein for much of the world, allowing for water savings of $300-390 \mathrm{~km}^{3} \mathrm{y}^{-1}(4-5 \%)$ globally. While these values are small compared to the current water footprint of human food production $\left(7,600 \mathrm{k} \mathrm{km}^{3} \mathrm{y}^{-1}\right)$, such water savings may become increasingly important globally to feed a growing population. Additionally, water savings from marine protein may already be important to the food and water security of specific countries, particularly economically disadvantaged and water scarce nations.

The contribution of marine protein to water savings is highly uneven around the globe (Figure 4.1). Percent increases reveal which countries experience the largest current water savings from marine protein consumption relative to current water consumption. National percent increases range from a minimum of a $0.04-0.06 \%$ increase in Mongolia to a maximum of a $42-$ $50 \%$ increase in Maldives (Figure 4.1). The importance of water savings from marine protein to food and water security varies greatly due to differences in reliance on marine fish protein, the water footprints of substitute terrestrial protein, population size, and freshwater availability.

Figure 4.2 presents the relative importance of marine protein to food and water security by comparing each country's agricultural land and renewable freshwater availability, with circle radii 
proportional to per capita water savings from marine protein consumption. The four quadrants (AD) of Figure 4.2 are based on agricultural land scarcity $(<0.1$ ha per capita) and countries with some degree of water stress $\left(<2500 \mathrm{~m}^{3} /\right.$ capita/year $)$.

For any given country, there are essentially three options for replacing marine protein with terrestrial protein: increase land under food cultivation, increase the productivity of land which generally involves irrigation and fertilizer application (Mueller et al. 2013), or increase importation of terrestrial foods. The first of these options is limited by national green water resources and available agricultural land, the second affects blue and grey water resources, and the third increases reliance on other countries' food and water resources. This last option (importation of food) may be limited by countries' political or economic environments (Fader et al. 2013, Seekell et al. 2011).

Countries with sufficient agricultural land, but low renewable water resources (Figure 4.2, quadrant A) are primarily countries in Africa and the Middle East. The countries with the largest per capita water savings and percent water saving from marine protein in quadrant A are Kiribati (1051 L/capita/day, 12-14\%), Samoa (707 L/capita/day, 12-13\%), and Ghana (417 L/capita/day, 12-13\%). Countries in quadrant A with lower water savings may also find water savings from marine protein important to food and water security since even small increases in blue water demand cannot be met domestically. In some cases countries in quadrant A may be able to replace some or all marine protein domestically by increasing green water use on agricultural lands, but irrigation is limited by low blue water availability.

Countries with both low agricultural lands and low renewable water resources (Figure 4.2, quadrant B) have a limited ability to increase terrestrial production domestically due to restricted land, green water, and blue water resources. Countries in quadrant B with a large water savings from marine protein include Maldives (1719 L/capita/day, 42-50\% WS), the Republic of Korea 
(665 L/capita/day, 12-18\% WS), and Barbados (552 L/capita/day, 9-10\% WS). These countries receive the greatest water benefit from marine protein (and consequently are most vulnerable to the loss of this protein). Many countries falling in this category are in the Middle East and Northern Africa, and have low water savings from marine protein. These countries may still find water savings from marine protein as important since land and renewable water are limited.

Only four countries are classified as having sufficient renewable water resources but insufficient land (Figure 4.2, quadrant C): Japan (767 L/capita/day, 18-23\%), Brunei Darussalam (236 L/capita/day, 2-3\%), Trinidad and Tobago (171 L/capita/day, 3-4\%), and Bangladesh (36 L/capita/day, 1-2\%). These countries may be able to increase terrestrial food production if yield can be increased on available agricultural land, but may be more likely to increase their external water footprint instead by importing terrestrial protein.

The majority of countries currently have both sufficient agricultural land and sufficient renewable water resources (Figure 4.2, quadrant D). For these countries, the water savings from marine protein consumption are typically less important for food and water security. There are however cases where the climate is unfavorable for terrestrial food production (e.g. Iceland), or technological and infrastructure limitations may prevent increased terrestrial food production. These countries may also increase their external footprint through trade if they were to replace marine protein with terrestrial protein.

Of the 25 countries with the largest per capita water savings from marine fish, seventeen are water sufficient, while five are already water scarce, one is stressed, and two are vulnerable (Figure 4.3). While island, Asian, and coastal African countries experience the largest per capita water savings and percent water savings relative to current water footprint, the countries with the largest total volumetric water savings from marine protein consumption are those with large 
populations and high terrestrial protein substitute water footprints. Multiplying the per capita increase by population reveals that the largest total water savings (in terms of water volume) occur in the China, Japan, Indonesia, and the United States (Figure 4.4).

Continuing or increasing freshwater savings through marine protein consumption depends on future human food preferences, populations growth, the future state of global fisheries, and the development of sustainable aquaculture. As noted, water savings from marine protein consumption is dependent on the water costs of alternate terrestrial protein sources. Meat consumption levels are generally high in developed countries, but are increasing rapidly in developing countries (Delgado 2003; Tilman et al., 2009). If the current increase in meat consumption continues, replacing marine protein with terrestrial protein will require more water on average. These water costs may however be reduced through technological advances and improved water use efficiency (Hoekstra and Chapagain 2007). Further, future per capita and national savings from marine protein consumption depend on whether marine capture fishery and aquaculture production can keep up with population growth. For example, if marine production remains at current levels until 2050, a calculation with FAO population projections reveals that global per capita marine protein consumption would decline by $0.8 \mathrm{~g} /$ day. National changes in per capita marine protein consumption multiplied by the water footprint of replacing this protein with terrestrial protein yields a global increase of $55-75 \mathrm{~km}^{3} \mathrm{y}^{-1}(0.7-1 \%$ increase over current water use).

Maintaining or increasing water savings from marine protein is highly dependent on the future production levels of marine capture and aquaculture fisheries. Marine and freshwater capture fishery production has leveled off in recent years (FAO 2012), and there has been much controversy over the future trajectory of global fisheries (Worm et al. 2009). Additional changes in fisheries production due to climate change has added to the uncertainty about the future of global 
fisheries and aquaculture (Cheung et al. 2013, Merino et al. 2012). Effective management of capture fisheries however has the potential to not only avoid fishery collapses, but to allow for rebuilding and possibly increased yield (Worm et al. 2009, Costello et al. 2012). Such efforts can contribute to long-run food and water security, but may have short-term social and economic impacts from fishing restrictions (Worm et al. 2009). Included in these pressures on fisheries are current trends to establish marine protected areas (MPAs) that limit or ban fishing. These MPAs may benefit specific fisheries but may also have hidden environmental costs as humans switch to other food sources (Hilborn 2013).

While the state of global fisheries is controversial, there are specific fisheries known to be in decline, with small unassessed fisheries in significantly worse condition than large assessed ones (Costello et al. 2012). Since the importance of marine fish protein to domestic food and water security is spatially variable, specific regions are more adversely impacted by fishery declines than others. Consequently, nations which are most vulnerable to fisheries declines should incorporate water security as an additional risk factor in fisheries management as well as in the cost-benefit analysis of entering into international fishing agreements. These agreements are of particular concern for developing nations in West Africa and South East Asia, where foreign nations frequently fish both legally and illegally, but monitoring is limited (Mallory 2013) and fish catches are systematically underreported (Pauly et al. 2013).

Rising global aquaculture production suggests that this industry may be able to replace some protein currently provided by capture fisheries (Duarte 2009) and increase the global water savings from marine protein. Future water savings from marine aquaculture, however, is dependent on its sustainable development. First, the use of capture fisheries for the production of fish meal and fish oil for feed can lead to a net loss of fish protein for some aquaculture systems (Naylor 
2000, Tacon and Metian 2009). Some have therefore suggested that aquaculture should incorporate more terrestrially-based feed (Bell and Waagbo 2008), but this change would increase the water footprint of marine aquaculture. This can be observed in analyses which have found that water requirements for feed in some freshwater aquaculture systems are already quite high (Verdegem and Bosma 2009). In order to reduce the costs associated with feeds, sustainable aquaculture could focus on lower trophic species and integrated production systems, which can reduce effluents, diversify products and increase productivity (Naylor et al. 2000). The development of sustainable aquaculture is likely an important component of meeting the increasing protein demands of a growing population without substantially increasing the water footprint of humanity.

It is important to note that when considering the costs of replacing fish protein with terrestrial protein, water resources are not the only constraints or environmental impacts to consider. Changes in food production patterns have important implications for carbon, nitrogen, and phosphorus cycles as well as land use. For example, the increased land required to produce terrestrial protein to replace fish protein has been demonstrated to be substantial (13-63\% increase) in a case study of the Mekong River basin (Orr et al. 2012). Such impacts are also important to consider when evaluating tradeoffs between marine capture and aquaculture fisheries. For example, while aquaculture production can result in high nutrient levels in surrounding waters (Islam 2005), capture fisheries are typically more energy intensive than many aquaculture systems (Costa-Pierce et al. 2010). Additionally, in some cases there may be social, political and economic constraints that would prevent marine protein from being entirely replaced with terrestrial protein. In countries where there are not protein deficiencies, this may not be problematic, but in other countries, a decline in per capita fish protein would mean that more people would not be able to meet their protein needs. This would lead to higher rates of malnutrition, while increasing pressure 
on water resources, outcomes contrary to the Millennium Development Goals (United Nations 2010).

\section{Conclusion}

Water and food resources are inextricably linked, and the water resource implications of changes in fisheries practices must therefore be considered. This study demonstrates the large freshwater savings from marine fish consumption, particularly in Asia, Oceania, and several coastal African nations. These substantial water savings should be accounted for in the consideration of fisheries management policies and in the promotion of sustainable aquaculture. Further, the unequal importance of water savings from marine fish should be integrated into future international fishing agreements to protect the joint global food and water security. 


\section{References}

Bell, JG and R Waagbo (2008) Safe and nutritious aquaculture produce: benefits and risks of alternative sustainable aquafeeds. In Aquaculture in the ecosystem (eds M. Holmer, K. Black, C. M. Duarte, N. Marba \& I. Karakassis), pp. 185-225. Berlin, Germany: Springer.

Boyd, CE, C Tucker, A McNevin, K Bostick and J Clay (2007) Indicators of resource use efficiency and environmental performance in fish and crustacean aquaculture. Reviews in Fisheries Science, 15: 336-360.

Carr, JA, P D’Odorico, F Laio, L Ridolfi (2012) Recent history and geography of virtual water trade. PLoS-ONE, 8(2): e55825. doi:10.1371/ journal.pone.0055825, 2013.

Cassidy, ES, PC West, JS Gerber and JA Foley (2013) Redefining agricultural yields: from tonnes to people nourished per hectare. Environmental Research Letters, 8 doi:10.1088/17489326/8/3/034015.

Cheung, WWL, R Watson and D Pauly (2013) Signature of ocean warming in global fisheries catch. Nature, 497: 365-368.

Costa-Pierce, BA (2010) Sustainable aquaculture systems: the need for a new social contract for aquaculture development. Marin Technology Society Journal, 44(3): 88-112.

Costello, C (2012) Status and solutions for the world's unassessed fisheries. Science, 338: $517-$ 520.

Delgado, CL (2003) Rising consumption of meat and milk in developing countries has created a new food revolution. American Society for Nutritional Sciences, 133(Suppl. 2): 3907S3910S.

Duarte, C, M Holmer, Y Olsen, D Soto, N Marbà, J Guiu, K Black and I Karakassis (2009) Will the oceans help feed humanity?. BioScience, 59(11): 967-976.

Fader, M, D Gerten, M Krause, W Lucht and W Cramer (2013) Spatial decoupling of agricultural production and consumption: quantifying dependences of countries on food imports due to domestic land and water constraints. Environmental Research Letters doi:10.1088/17489326/8/1/014046.

FAO. (2013) AQUASTAT database, Food and Agriculture Organization of the United Nations (FAO). Accessed (14 Jan 2013). 
Food and Agriculture Organization of the United Nations. FAOSTAT. Commodity Balances, Crops, Primary Equivalent (Dataset). (Latest update: 02 May 2012) Accessed (2 Jan 2013). URI: http://ref.data.fao.org/ac2f9731-8464-4589-89fd-7e8242009929

Food and Agriculture Organization (FAO) (2009) Fishery and aquaculture statistics. Rome, Italy.

Hilborn, R (2013) Environmental cost of conservation victories. Proceedings of the National Academy of Sciences 110(23): 9187.

Hoekstra, AY (2003) Virtual water: An introduction. In: Virtual Water Trade: Proceedings of the International Expert Meeting on Virtual Water Trade, February 2003.

Hoekstra, AY and Chapagain AK (2007) Water footprints of nations: Water use by people as a function of their consumption pattern. Water Resource Management, 21: 35-48.

Hoekstra, AY, AK Chapagain, MM Aldaya and MM Mekonnen (2011) The water footprint assessment manual: Setting the global standard, Earthscan, London, UK.

Islam, S (2008) Nitrogen and phosphorus budget in coastal and marine cage aquaculture and impacts of effluent loading on ecosystem: review and analysis towards model development. Marine Pollution Bulletin, 50(1): 48-61.

Kent, G (2003) Fish trade, food security and the human right to adequate food. In: Report of the FAO Expert Consultation on International Fish Trade and Food Security. Casablanca, Morocco 27-30 January 2003. FAO Fisheries Report No. 708, FAO, Rome, pp. 49-70.

Mallory, TG (2013) China's distant water fishing industry: Evolving policies and implications. Marine Policy, 38: 99-108.

Mekonnen, M and AY Hoekstra (2010) The green, blue and grey water footprint of farm animals and animal products. Value of Water Research Report Series No. 48, UNESCO-IHE, Delft, the Netherlands.

Mekonnen, MM and AY Hoekstra (2011) National water footprint accounts: the green, blue and grey water footprint of production and consumption, Value of Water Research Report Series No.50, UNESCO-IHE, Delft, the Netherlands.

Merino, G, M Barange, JL Blanchard, J Harle, R Holmes, I Allen, EH Allison, MC Badjeck, NK Dulvy, J Holt, S Jennings, C Mullon and LD Rodwell (2012) Can marine fisheries and aquaculture meet fish demand from a growing human population and changing climate? Global Environmental Change, 22:795-806. 
Mueller, ND, JS Gerber, M Johnston, DK Ray, N Ramankutty and JA Foley (2012) Closing yield gaps through nutrient and water management. Nature, 490: 254-257.

Naylor, RL, RJ Goldburg, JH Primavera, N Kautsky, MCM Beveridge, J Clay, C Folke, J Lubchenco, H Mooney and M Troell (2000) Effect of aquaculture on world fish supplies. Nature, 405: 1017-1024.

Orr, S, J Pittock, A Chapagain and D Dumaresq (2012) Dams on the Mekong River: Lost fish protein and the implications for land and water resources. Global Environmental Change, 22: 925-932.

Pauly, D, D Belhabib, R Blomeyer, WWWL Cheung, AM Cisneros-Montemayor, D Copeland, S Harper, VWY Lam, Y Mai, FL Manach, H Österblom, KM Mok, L van der Meer, A Sanz, S Shon, UR Sumaila, W Swartz, R Watson, Y Zhai and D Zeller (2013) China's distantwater fisheries in the $21^{\text {st }}$ century. Fish and Fisheries, doi:10.111/faf.12032.

Ridoutt, BG and S Pfister (2010) A revised approach to water footprinting to make transparent the impacts of consumption and production on global freshwater scarcity. Global Environmental Change, 20:113-120.

Rockstrom, J, M Falkenmark, L Karlberg, H Hoff, S Rost and D Gerten (2009) Future water availability for global food production: The potential of green water for increasing resilience to global change. Water Resources Research, doi:10.1029/2007WR006767.

Seekell, DA, P D’Odorico, ML Pace (2011) Virtual water transfers unlikely to redress inequality in global water use. Environmental Research Letters, 6:024017, doi: 10.1088/17489326/6/2/024017.

Tacon, A and M Metian (2009) Fishing for feed or fishing for food: Increasing global competition for small pelagic forage fish. Ambio, 38(6): 294-302.

Tilman, D, C Balzer, J Hill, BL Befort (2011) Global food demand and the sustainable intensification of agriculture, Proceedings of the National Academy of Sciences 108: 20260-20264.

United Nations (2010) The millennium development goals report. New York, NY, June 2010.

United Nations Environment Programme (UNEP) (2012) 21 issues for the $21^{\text {st }}$ century. In: Results of the UNEP Foresight Process on Emerging Environmental Issues.

Vergegem, MCJ and RH Bosma (2009) Water withdrawal for brackish and inland aquaculture, and options to produce more fish in ponds with present water use. Water Policy, 11: 5268. 
Verdegem, MCJ, RH Bosma and JAJ Verreth (2006) Reducing Water Use for Animal Production through Aquaculture. International Journal of Water Resources Development, 22(1).

Worm, B, R Hilborn, JK Baum, TA Branch, JS Collie, C Costello, MJ Fogarty, EA Fulton, JA Hutchings, S Jennings, OP Jensen, HK Lotze, PM Mace, TR McClanahan, C Minto, SR Palumbi, AM Parma, D Ricard, AA Rosenberg, R Watson and D Zeller (2009) Rebuilding global fisheries. Science, 325: 578-585.

WWAP (World Water Assessment Programme) (2012) The United Nations World Water Development Report 4: Managing Water under Uncertainty and Risk. Paris, UNESCO.

York, R and Gossard MH (2004) Cross-national meat and fish consumption: exploring the effects of modernization and ecological context. Ecological Economics, 48: 293-302. 
Table 4.1: Water footprints per gram of protein and the corresponding current protein consumption levels as a percent of total protein intake for the 12 food categories for the United States. The water footprint times the proportion of protein consumed yields a water footprint weighted by the consumption level. The sum of weighted water footprints yields the water footprint for 1 gram of protein based on that group of substitutes.

\begin{tabular}{|c|c|c|c|c|c|}
\hline \multirow[b]{2}{*}{$\begin{array}{c}\text { Food } \\
\text { Category }\end{array}$} & \multirow[b]{2}{*}{$\begin{array}{l}\text { WF } \\
(\mathrm{L} / \mathrm{g})\end{array}$} & \multicolumn{2}{|c|}{ All Substitutes } & \multicolumn{2}{|c|}{ Animal Substitutes } \\
\hline & & $\begin{array}{l}\text { Percent of } \\
\text { protein } \\
(\%)\end{array}$ & $\begin{array}{l}\text { Weighted } \\
\text { WF (L/g } \\
\text { protein) }\end{array}$ & $\begin{array}{l}\text { Percent of } \\
\text { protein } \\
(\%)\end{array}$ & $\begin{array}{l}\text { Weighted } \\
\text { WF (L/g } \\
\text { protein) }\end{array}$ \\
\hline Vegetables & 26 & 2.3 & 0.60 & - & - \\
\hline Starchy roots & 31 & 2.2 & 0.68 & - & - \\
\hline Fruits & 180 & 2.1 & 3.78 & - & - \\
\hline Cereals & 21 & 21.6 & 4.54 & - & - \\
\hline Pulses & 19 & 2.5 & 0.48 & - & - \\
\hline Nuts & 139 & 2.1 & 2.92 & - & - \\
\hline Milk & 31 & 28.4 & 8.80 & 42.2 & 13.08 \\
\hline Eggs & 29 & 3.7 & 1.07 & 5.4 & 1.57 \\
\hline Chicken & 34 & 15.7 & 5.34 & 23.4 & 7.96 \\
\hline Pig & 57 & 7.2 & 4.10 & 10.8 & 6.16 \\
\hline $\begin{array}{l}\text { Sheep and } \\
\text { goat }\end{array}$ & 63 & 0.2 & 0.13 & 0.3 & 0.19 \\
\hline Bovine & 112 & 12.0 & 13.44 & 17.9 & 20.05 \\
\hline $\begin{array}{l}\text { Substitute WF } \\
\text { (L/g protein) }\end{array}$ & - & - & 45.88 & - & 49.00 \\
\hline
\end{tabular}


Table 2: Current marine protein consumption levels multiplied by the calculated water footprints for the two groups of substitutes in five countries gives the daily per capita water savings. Five countries are presented as examples. Comparing these values to current water footprints gives the percent increase. All Subs means that all food sources were weighted to calculate the average water footprint for a gram of protein, while Animal Subs means that only animal food sources were used.

\begin{tabular}{|c|c|c|c|c|c|}
\hline Country & $\begin{array}{l}\text { Marine protein } \\
\text { Consumption } \\
\text { (g protein/cap/day) }\end{array}$ & $\begin{array}{l}\text { Substitute WFP } \\
\text { (1/g protein) }\end{array}$ & $\begin{array}{l}\text { WFP Increase } \\
\text { (1/cap/day) }\end{array}$ & $\begin{array}{l}\text { Current WFP } \\
\text { (1/cap/day) }\end{array}$ & $\begin{array}{l}\text { Percent } \\
\text { Increase }\end{array}$ \\
\hline Solomon Islands & 11.0 & & & 1978.7 & \\
\hline All Subs & & 39.6 & 435.6 & & 22.0 \\
\hline Animal Subs & & 70 & 770.0 & & 38.9 \\
\hline Gambia & 6.8 & & & 2428.1 & \\
\hline All Subs & & 32.3 & 219.8 & & 9.0 \\
\hline Animal Subs & & 47.6 & 323.7 & & 13.3 \\
\hline Denmark & 6.4 & & & 4475.2 & \\
\hline All Subs & & 41.6 & 266.2 & & 5.9 \\
\hline Animal Subs & & 45.7 & 292.5 & & 6.5 \\
\hline United States & 4.4 & & & 7782.2 & \\
\hline All Subs & & 45.9 & 202.0 & & 2.6 \\
\hline Animal Subs & & 49 & 215.6 & & 2.8 \\
\hline Lesotho & 0.2 & & & 4488.8 & \\
\hline All Subs & & 26 & 5.2 & & 0.1 \\
\hline Animal Subs & & 61.7 & 12.3 & & 0.3 \\
\hline
\end{tabular}




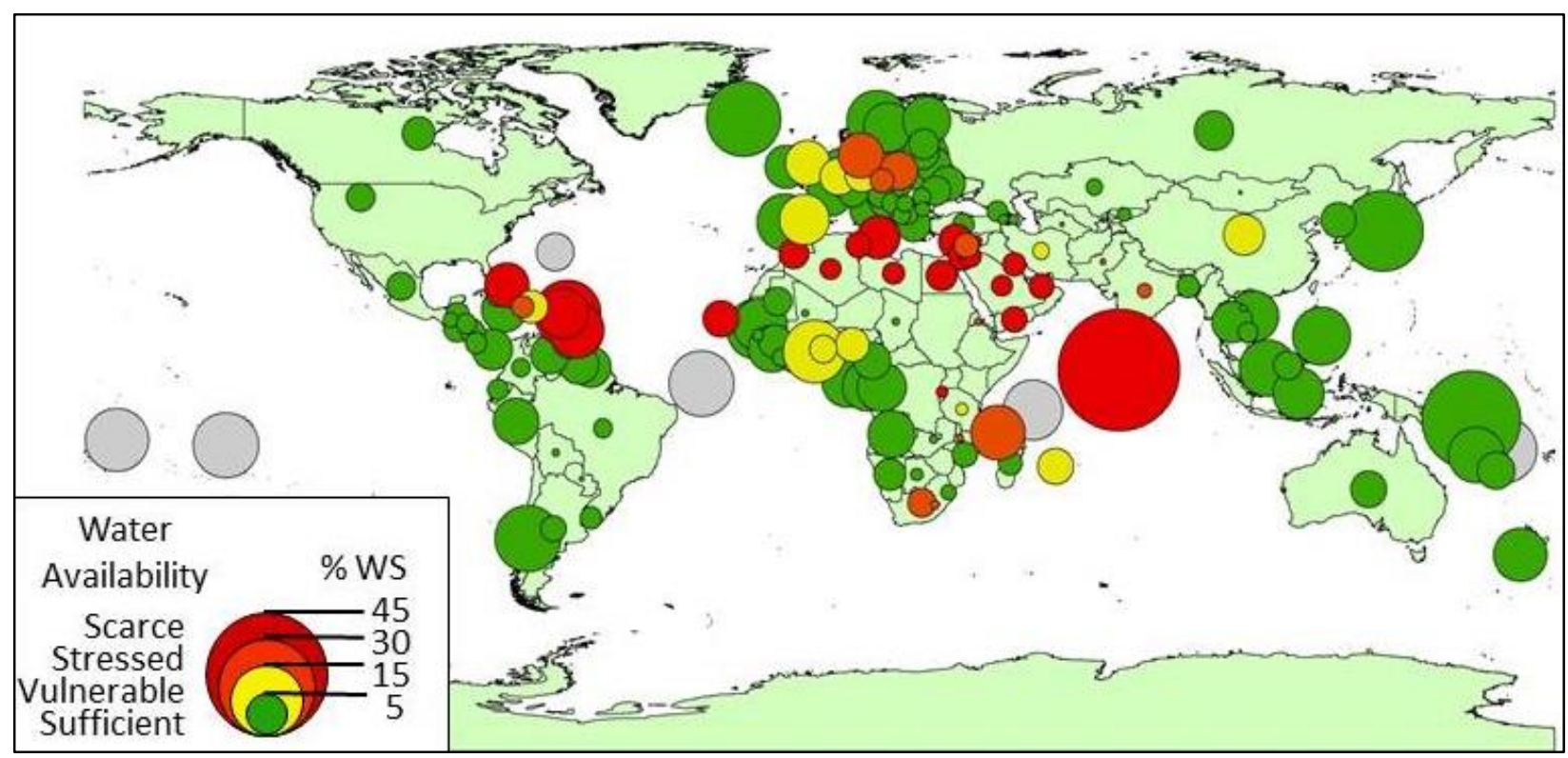

Figure 4.1: Bubble area is proportional to the percent water savings from marine fish protein.

Bubble color represents current water scarcity status, where red is scarce, orange is stressed, yellow is vulnerable, and green is sufficient, according to United Nations standards (grey indicates lack of data on renewable water resources). 


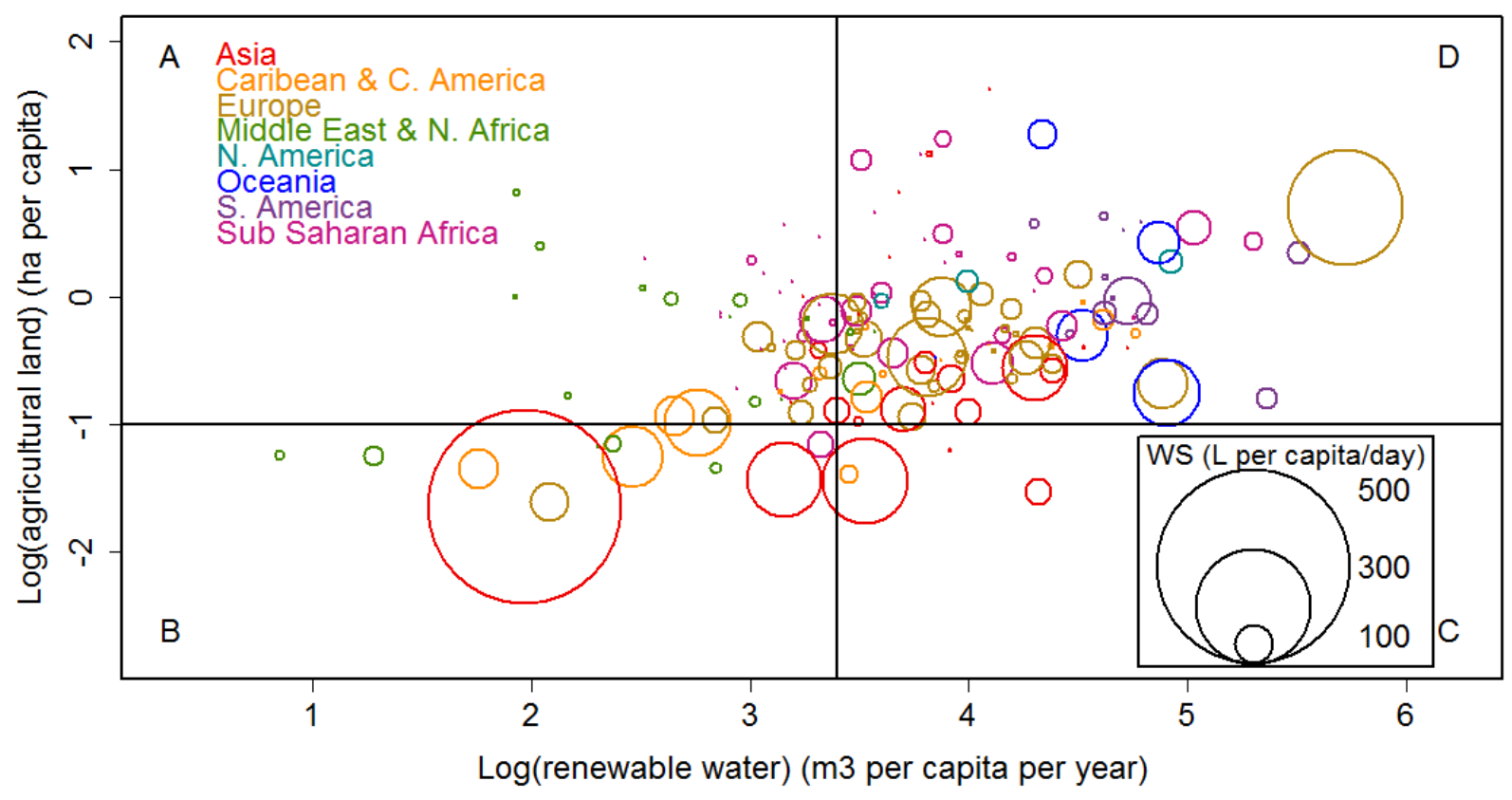

Figure 4.2: The logarithm of annual renewable water resources was plotted against the logarithm of the total agricultural land for each country. The vertical line at $\log (2500)$ distinguishes water sufficient from water scarce, while the horizontal line at $\log (0.1)$ distinguishes sufficient agricultural land from insufficient agricultural land based on the estimated minimum agricultural land requirement estimated by Cassidy et al. 2013. The radius of each circle is proportional to the per capita water savings from marine protein consumption in each country. Each country's geographic region is indicated by the circle color. 


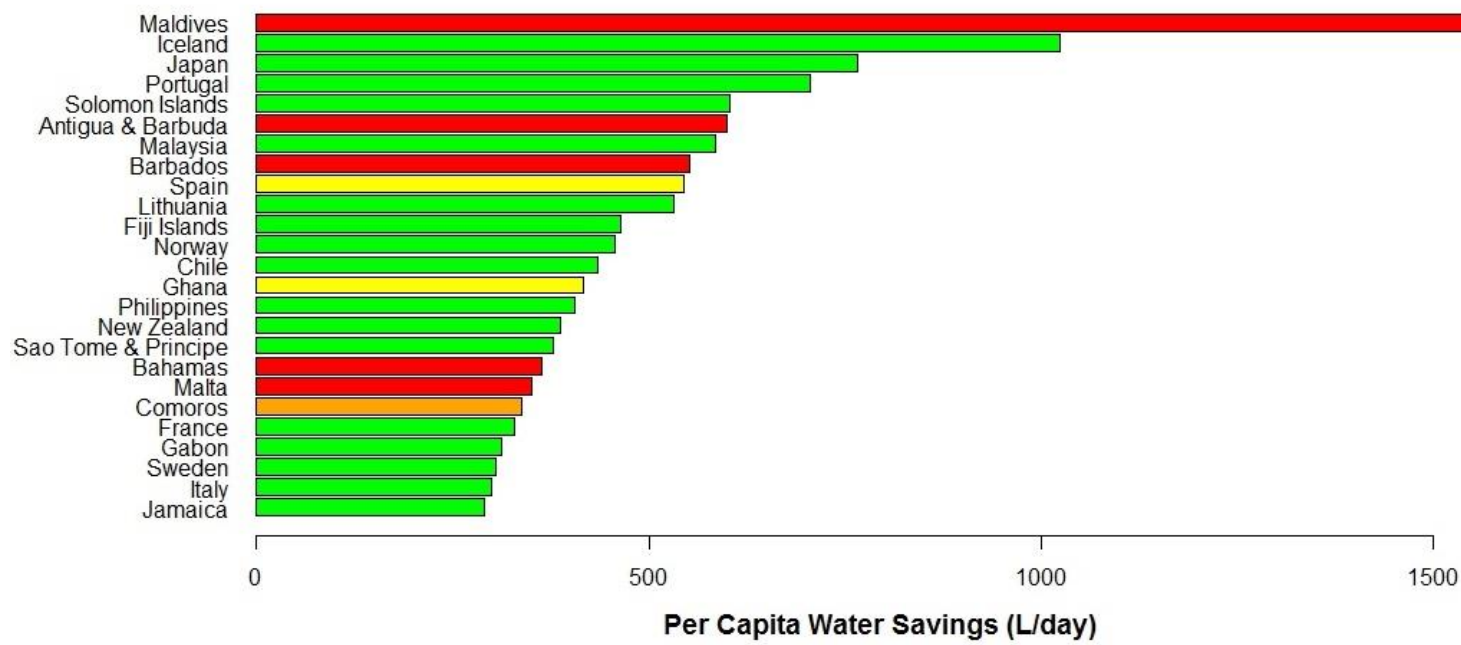

Figure 4.3: Per capita water savings from marine fish consumption (L/day) for the top 25 countries. The color of the bar represents the current water scarcity status of each country, where red is scarce, orange is stressed, yellow is vulnerable, and green is sufficient, according to United Nations standards. 


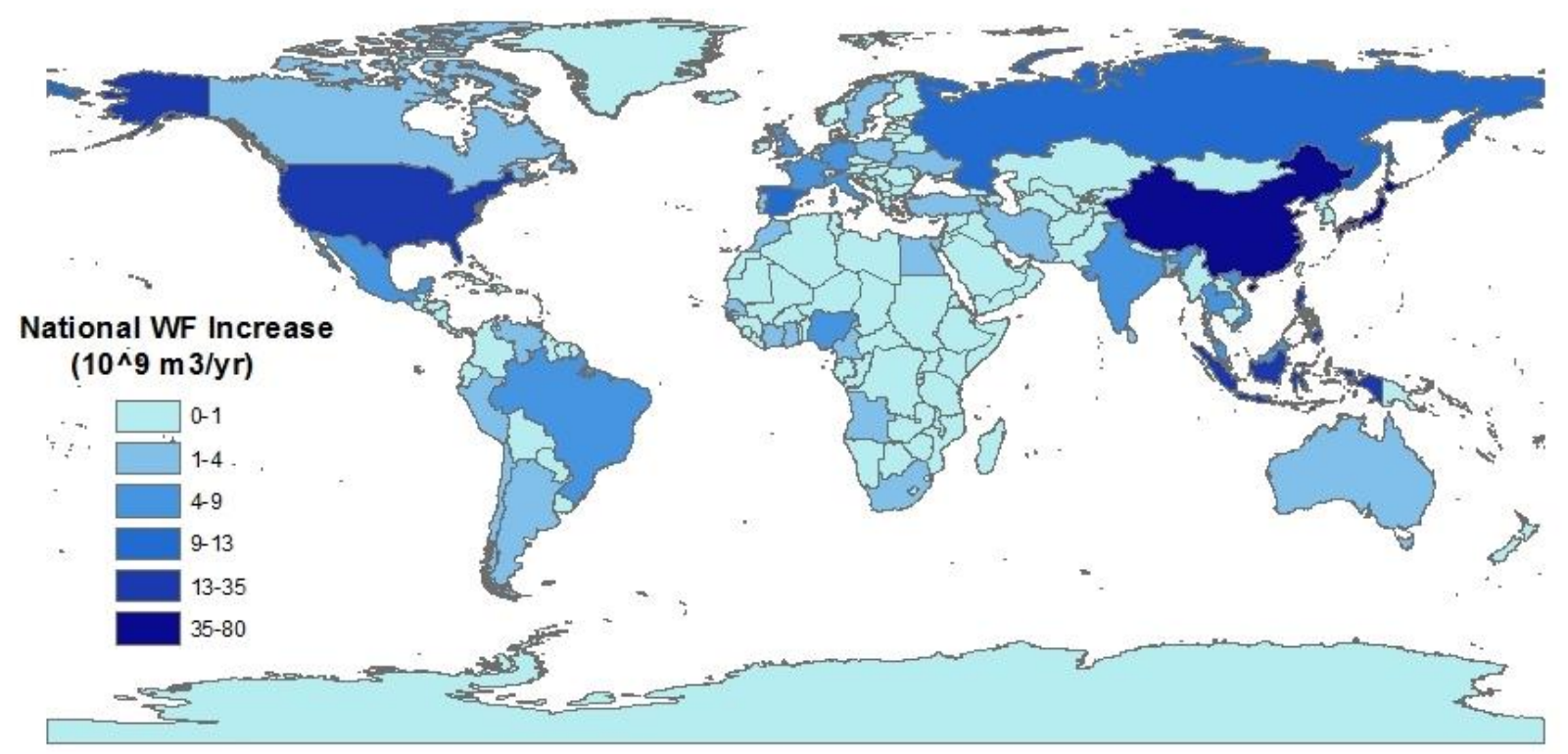

Figure 4.4: National increases in water footprints in the absence of marine fish protein $\left(10^{9} \mathrm{~m}^{3} / \mathrm{yr}\right)$. 


\section{SUMMARY AND CONCLUSIONS}

This dissertation quantifies the globalization of seafood (Chapter 1) and presents three novel perspectives on vulnerability and resilience in the global seafood system (Chapter 2-4). The global seafood trade network was reconstructed for 1994 to 2012 to track the evolution of the trade network's structure (Chapter 1). Over that period the total value of traded seafood (in real terms) nearly doubled, with the largest trade increases occurring within regions and from exports from Southeast and Eastern Asia. These trade increases coincide with large increases in the influence of Thailand and China in the network. Concurrent with this restructuring, the overall globalization of seafood products increased, as indicated by the increasing average numbers of trade partnerships, the shift in the distribution of the number of trade partnerships, and the increasing network clustering. This network analysis provides new insights into global seafood trade, including that the increase in trade and connectedness is similar in magnitude to the agricultural network and the increasing network influence of China and Thailand, coinciding with their periods of rapid aquaculture growth.

An increasingly globalized seafood trade network allows for buffering against local shocks, but also exposes regions to external shocks. Evaluating exposure to such shocks helps assess vulnerability and risk within the global food system. A forward propagation model quantifies the response of the global seafood trade network to potential environmental and policy perturbations (Chapter 2). Vulnerability was then assessed by comparing changes in national fish supplies to indices of each country's nutritional seafood dependency. The regions with higher imports, notably West Africa, Eastern Asia, and Southern and Western Europe tended to be most exposed within the network. As major exporters, Northern Europe, Eastern Asia, and Southeast 
Asia have the most significant influence initiating shocks in the network. Comparing exposure to sensitivity revealed West and Central Africa to be relatively vulnerable to shocks within the network, with West Africa becoming increasingly vulnerable when a GDP effect was included. The vulnerability of these regions is further emphasized by the low adaptive capacity previously reported in nearly all African countries. The methods developed in this study represent an important step in understanding how shocks are transmitted and where the highest risks are to external shocks in a food commodity trade network.

Chapter 3 uses a statistical shock identification approach with a complementary qualitative approach to identify shocks in fisheries catch time series. Based on the set of identified shocks, this chapter finds no trend in the frequency or magnitude of shocks in the aggregated production or in the magnitude of shocks in the species production, but does support an increase in the shock frequency in the species time series. The highest number of shocks occurred in Europe, Africa, and Asia, which also tended to have shocks of larger magnitude. Shock rates and magnitudes were similar among species groups, but shocks occurred more frequently in aquaculture systems than capture systems. Further, when shocks occur countries tend to increase imports, increase and decrease exports equally, and tend to experience decreases in supply. Since the impact of a particular shock is context dependent, this chapter also describes four case studies of shocks. Through the analysis of patterns in historical shocks, this chapter identifies potential vulnerabilities in the seafood production system. Further, evaluating the impact of shocks informs whether and when a regional shock will have more distant impacts through international trade, while evaluating the impact of shocks on seafood supply informs whether and when shocks may impact local nutrient availability. 
In addition to adapting to changes in domestic seafood production through trade, countries can alter production of other food sources. Chapter 4 evaluates the water cost and ability of countries to replace marine protein with terrestrial foods based on current consumption patterns and water resources. Replacing marine protein with terrestrial protein would require an additional $350 \mathrm{~km} 3 \mathrm{y}-1$ of water. This can alternatively be viewed as a current water savings of 4.6\%. The importance of these freshwater savings is highly uneven around the globe, with savings ranging from as little as 0 to as much as $50 \%$. Of the 25 countries with the highest water savings from marine protein consumption, eight are already experiencing some form of water stress. This indicates that marine protein is an important component of their joint food-water security.

Seafood is becoming increasingly global, with implications for vulnerability and resilience in the global seafood production and trade system. Seafood production interacts with the environment in two ways: by altering the environment through resource use and extraction, while the environment impacts seafood production through climate variability and natural disasters. Shifts in environmental impacts of seafood production are co-occurring with globalization, through the increase in aquaculture production, concerns of overfishing, and consumers being connected to new, distant fisheries. At the same time, countries are increasingly connected to distant environmental and policy shocks through the global seafood trade network. These results have important implications for policy. First, measures to improve the sustainability of seafood consumed in a country must account for the increasing global trade of seafood. This can be facilitated through improved data collection along the supply chain and through reliable certification programs. Second, shocks to seafood production can impact domestic seafood supply either directly or through propagation via the global trade network. 
Historical examples of shocks can inform policy considerations for responding to such shocks. In the long-run, countries should weigh the risks of reliance on imports with the resources available to invest in changes in domestic production.

These findings raise important questions, including: 1) what are the magnitudes of the externalized environmental impacts of traded seafood production; 2) how will climate change shift capture fishery distributions and restructure global trade networks; 3) what are the distant impacts of local shocks in historical events; and 4) how do the food security vulnerabilities scale to the sub-national level? The trade network structure, models and case studies of shocks, and quantification of the joint food-water security reliance on seafood presented in this dissertation provide foundational knowledge and models upon which future research addressing these questions can be explored. 


\section{APPENDIX 1: CHAPTER 1 SUPPLEMENTARY MATERIAL}

Here we provide additional details on the analysis of potential bias by excluding "World," five additional figures, and one additional table referenced in the text. These figures illustrate the regression between the FishStat and Comtrade data, the imports reported from the "World" node over time, an alternative version of Figure 1.1 using FAO FishStat import and export data, the change in degree distribution, and the distribution of the length of trade relationships. We also provide a summary of the regression between FishStat and Comtrade total import and export data.

\section{Methods}

The imports from the "World" node could theoretically be distributed in any way among the exporters. If there is a bias in the reporting to "World," such that a country differentially claims imports from particular countries as coming from "World," then this would introduce errors in the structural analysis. However, if a country's imports from "World" are distributed proportionately to the imports from each of the exporters in the known trade network, then there is no structural bias from excluding world. The trade network is represented as a matrix with rows representing importers and columns representing exporters. Additional imports increase the row sums and can be distributed across the exporters in many ways, but changes in countries' exports to a given importer would have to maintain agreement with the column sums, or the total exports reported from each exporter.

In order to test whether the data support a distribution of the "World" imports proportional to the known network, we compared the total exports (row sums) in the Comtrade network to exports in FishStat (a separate database, see main text). The weighted trade network without 
"World" is represented by T, with importing countries on the rows and exporting countries on the columns. Then the matrix of proportionate imports, $\mathrm{P}$, is $\mathrm{T} / \mathrm{i}$, where $\mathrm{i}$ represents the total imports, or the row sums of the matrix. The trade matrix with "World" imports can then be calculated as $\mathrm{T}_{\mathrm{w}}=\mathrm{T}+\mathrm{P}^{*} \mathrm{w}$, where $\mathrm{w}$ is a vector of each country's imports reported from "World." The distribution of w among a country's exporters alters those countries' total exports. So each country's total exports, e (the column sums of $\mathrm{T}_{\mathrm{w}}$ ) can be compared to the reported total exports in FishStat to measure how well the distribution of w among exporters agrees with the FishStat export estimates. For 2011, a proportional distribution of the trade reported from "World" explains a high proportion of the variability in the FishStat exports $\left(r^{2}=0.69\right)$.

If $\mathrm{w}$ is distributed across exporters in non-proportional ways (indicating biased reporting), then the column sums would still need to agree with the FishStat data. We simulated 100,000 alternative matrices of proportions, with the elements of each row drawn from the Dirichlet distribution. The new trade network and new total exports were calculated for each matrix of proportions and exports were compared to FishStat exports. We generated a distribution of $\mathrm{r}^{2}$ from each regression. The $\mathrm{r}^{2}$ for distributing "World" proportionately to the known trade network falls in the upper tail of this distribution, with 0.9999994 of the distribution's density falling below it. From this we conclude that the reporting to "World" tends to be unbiased. In short, the constraint of comparison of Comtrade exports to FishStat exports indicates the trade attributed to "World" does not bias the structure of the network. 


\section{Additional Tables and Figures}

Supplementary Table 1: Slope and coefficient of determination for the regression through the origin of each country's imports (exports) reported in FishStat (aquatic plants, inedible products, fish meal, fish oil, sponges, corals, and shells excluded) versus the sum of imports (exports) for each country in the Comtrade data. A slope and $r^{2}$ of one would indicates a perfect match between the two datasets.

\begin{tabular}{|c|c|c|c|c|c|c|c|c|}
\hline Year & $\begin{array}{l}\text { Value } \\
\text { Import } \\
\text { Slope }\end{array}$ & $\begin{array}{c}\text { Value } \\
\text { Import } r^{2}\end{array}$ & $\begin{array}{l}\text { Value } \\
\text { Export } \\
\text { Slope }\end{array}$ & $\begin{array}{c}\text { Value } \\
\text { Export } \mathrm{r}^{2}\end{array}$ & $\begin{array}{l}\text { Quantity } \\
\text { Import } \\
\text { Slope }\end{array}$ & $\begin{array}{l}\text { Quantity } \\
\text { Import } r^{2}\end{array}$ & $\begin{array}{c}\text { Quantity } \\
\text { Export } \\
\text { Slope }\end{array}$ & $\begin{array}{l}\text { Quantity } \\
\text { Export } \mathrm{r}^{2}\end{array}$ \\
\hline 1994 & 0.93 & 0.999 & 1.01 & 0.983 & 1.11 & 0.962 & 1.03 & 0.885 \\
\hline 1995 & 0.94 & 0.996 & 1.04 & 0.984 & 1.22 & 0.965 & 1.16 & 0.929 \\
\hline 1996 & 0.94 & 0.997 & 1.04 & 0.979 & 1.14 & 0.953 & 1.15 & 0.942 \\
\hline 1997 & 0.95 & 0.996 & 1.02 & 0.967 & 1.24 & 0.944 & 1.16 & 0.952 \\
\hline 1998 & 0.95 & 0.995 & 1.02 & 0.956 & 1.17 & 0.942 & 1.20 & 0.945 \\
\hline 1999 & 0.95 & 0.995 & 1.03 & 0.954 & 1.20 & 0.956 & 1.12 & 0.936 \\
\hline 2000 & 0.96 & 0.999 & 1.05 & 0.960 & 1.09 & 0.946 & 1.12 & 0.954 \\
\hline 2001 & 0.98 & 0.999 & 1.05 & 0.969 & 1.21 & 0.966 & 1.16 & 0.953 \\
\hline 2002 & 0.96 & 0.998 & 1.02 & 0.964 & 1.08 & 0.954 & 1.11 & 0.954 \\
\hline 2003 & 0.99 & 0.999 & 1.01 & 0.964 & 1.02 & 0.972 & 1.03 & 0.965 \\
\hline 2004 & 0.96 & 0.996 & 1.00 & 0.968 & 1.03 & 0.958 & 1.05 & 0.968 \\
\hline 2005 & 0.97 & 0.996 & 1.00 & 0.970 & 0.98 & 0.966 & 1.03 & 0.950 \\
\hline 2006 & 0.98 & 0.998 & 1.01 & 0.976 & 1.01 & 0.966 & 1.02 & 0.970 \\
\hline 2007 & 0.98 & 0.998 & 1.02 & 0.977 & 0.98 & 0.968 & 0.99 & 0.953 \\
\hline 2008 & 0.97 & 0.997 & 1.00 & 0.977 & 0.96 & 0.971 & 0.95 & 0.962 \\
\hline 2009 & 0.98 & 0.997 & 0.98 & 0.975 & 0.90 & 0.959 & 0.96 & 0.966 \\
\hline 2010 & 0.98 & 0.998 & 0.94 & 0.969 & 0.99 & 0.979 & 0.95 & 0.966 \\
\hline 2011 & 0.98 & 0.999 & 0.93 & 0.970 & 0.91 & 0.964 & 0.94 & 0.975 \\
\hline
\end{tabular}


Supplementary Table 2: List of countries or territories representing nodes in the analysis.

\begin{tabular}{|c|c|c|c|c|}
\hline Albania & Congo & Guinea Bissau & Morocco & Seychelles \\
\hline Algeria & Cook Islands & Guyana & Mozambique & Sierra Leone \\
\hline Angola & Costa Rica & Haiti & Myanmar & Singapore \\
\hline $\begin{array}{l}\text { Antigua and } \\
\text { Barbuda }\end{array}$ & Croatia & Honduras & Namibia & Slovakia \\
\hline Argentina & Côte d'Ivoire & Hungary & Nepal & Slovenia \\
\hline Armenia & Cuba & Iceland & $\begin{array}{l}\text { Netherlands } \\
\text { Antilles }\end{array}$ & Solomon Islands \\
\hline Aruba & Curacao & India & Netherlands & Somalia \\
\hline Australia & Cyprus & Indonesia & New Caledonia & South Africa \\
\hline Austria & Czech Rep. & Iran & New Zealand & Spain \\
\hline Azerbaijan & $\begin{array}{l}\text { Dem Peoples Rep } \\
\text { of Korea }\end{array}$ & Iraq & Nicaragua & Sri Lanka \\
\hline Bahamas & $\begin{array}{l}\text { Dem. Rep. of the } \\
\text { Congo }\end{array}$ & Ireland & Niger & Sudan \\
\hline Bahrain & Denmark & Israel & Nigeria & Suriname \\
\hline Bangladesh & Djibouti & Italy & Norway & Swaziland \\
\hline Barbados & Dominica & Jamaica & $\begin{array}{l}\text { Occ. Palestinian } \\
\text { Terr. }\end{array}$ & Sweden \\
\hline Belarus & Dominican Rep. & Japan & Oman & Switzerland \\
\hline $\begin{array}{l}\text { Belgium and } \\
\text { Luxembourg }\end{array}$ & Ecuador & Jordan & Pakistan & Syria \\
\hline Belize & Egypt & Kazakhstan & Palau & $\begin{array}{l}\text { TFYR of } \\
\text { Macedonia }\end{array}$ \\
\hline Benin & El Salvador & Kenya & Panama & Thailand \\
\hline Bermuda & Equatorial Guinea & Kiribati & $\begin{array}{l}\text { Papua New } \\
\text { Guinea }\end{array}$ & Timor Leste \\
\hline Bhutan & Estonia & Kuwait & Paraguay & Togo \\
\hline Bolivia & $\begin{array}{l}\text { Ethiopia and } \\
\text { Eretrea }\end{array}$ & Kyrgyzstan & Peru & Tonga \\
\hline $\begin{array}{l}\text { Bosnia } \\
\text { Herzegovina }\end{array}$ & Faeroe Islands & $\begin{array}{l}\text { Lao Peoples Dem } \\
\text { Rep }\end{array}$ & Philippines & $\begin{array}{l}\text { Trinidad and } \\
\text { Tobago }\end{array}$ \\
\hline Botswana & Falkland Islands & Latvia & Poland & Tunisia \\
\hline Brazil & Fiji & Lebanon & Portugal & Turkey \\
\hline $\begin{array}{l}\text { Brunei } \\
\text { Darussalam }\end{array}$ & Finland & Lesotho & Qatar & Turkmenistan \\
\hline Bulgaria & France & Liberia & Rep of Korea & $\begin{array}{l}\text { Turks and Caicos } \\
\text { Islands }\end{array}$ \\
\hline Burkina Faso & French Guiana & Libya & Rep of Moldova & Tuvalu \\
\hline Burundi & French Polynesia & Lithuania & Réunion & Uganda \\
\hline Cambodia & FS Micronesia & Madagascar & Romania & Ukraine \\
\hline Cameroon & Gabon & Malawi & $\begin{array}{l}\text { Russian } \\
\text { Federation }\end{array}$ & $\begin{array}{l}\text { United Arab } \\
\text { Emirates }\end{array}$ \\
\hline
\end{tabular}




\begin{tabular}{|c|c|c|c|c|}
\hline Canada & Gambia & Malaysia & Rwanda & United Kingdom \\
\hline Cape Verde & Georgia & Maldives & Saint Helena & $\begin{array}{l}\text { United Rep of } \\
\text { Tanzania }\end{array}$ \\
\hline Cayman Islands & Germany & Mali & $\begin{array}{l}\text { Saint Kitts and } \\
\text { Nevis }\end{array}$ & Uruguay \\
\hline $\begin{array}{l}\text { Central African } \\
\text { Rep. }\end{array}$ & Ghana & Malta & Saint Lucia & USA \\
\hline Chad & Greece & Marshall Islands & $\begin{array}{l}\text { Saint Pierre and } \\
\text { Miquelon }\end{array}$ & Uzbekistan \\
\hline Chile & Greenland & Martinique & $\begin{array}{l}\text { Saint Vincent and } \\
\text { the Grenadines }\end{array}$ & Vanuatu \\
\hline China & Grenada & Mauritania & Samoa & Venezuela \\
\hline $\begin{array}{l}\text { China Hong Kong } \\
\text { SAR }\end{array}$ & Guadeloupe & Mauritius & $\begin{array}{l}\text { Sao Tome and } \\
\text { Principe }\end{array}$ & Viet Nam \\
\hline $\begin{array}{l}\text { China Macao } \\
\text { SAR }\end{array}$ & Guam & Mayotte & Saudi Arabia & Yemen \\
\hline Colombia & Guatemala & Mexico & Senegal & Zambia \\
\hline Comoros & Guinea & Mongolia & $\begin{array}{l}\text { Serbia and } \\
\text { Montenegro }\end{array}$ & Zimbabwe \\
\hline
\end{tabular}



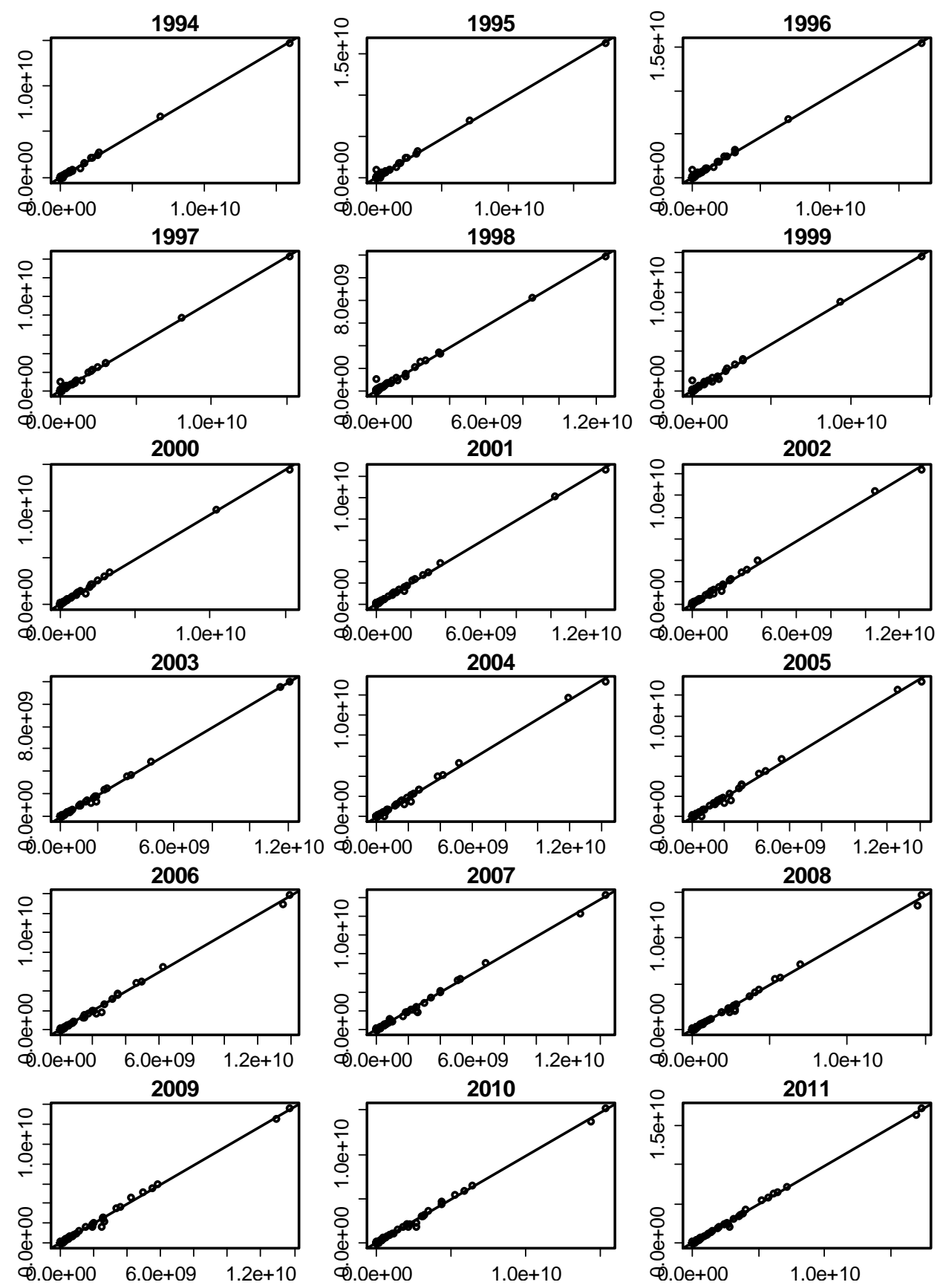

Supplementary Figure 1: Scatterplots with regression lines comparing the FishStat total import data to each country's total imports (USD) in Comtrade (summed across imports from each exporter). Regression coefficients and $\mathrm{r}^{2}$ values are presented in SI Table 1. Plots for quantity data are similar and regression coefficients and $r^{2}$ values for quantity data are also presented in Supplementary Table 1. 

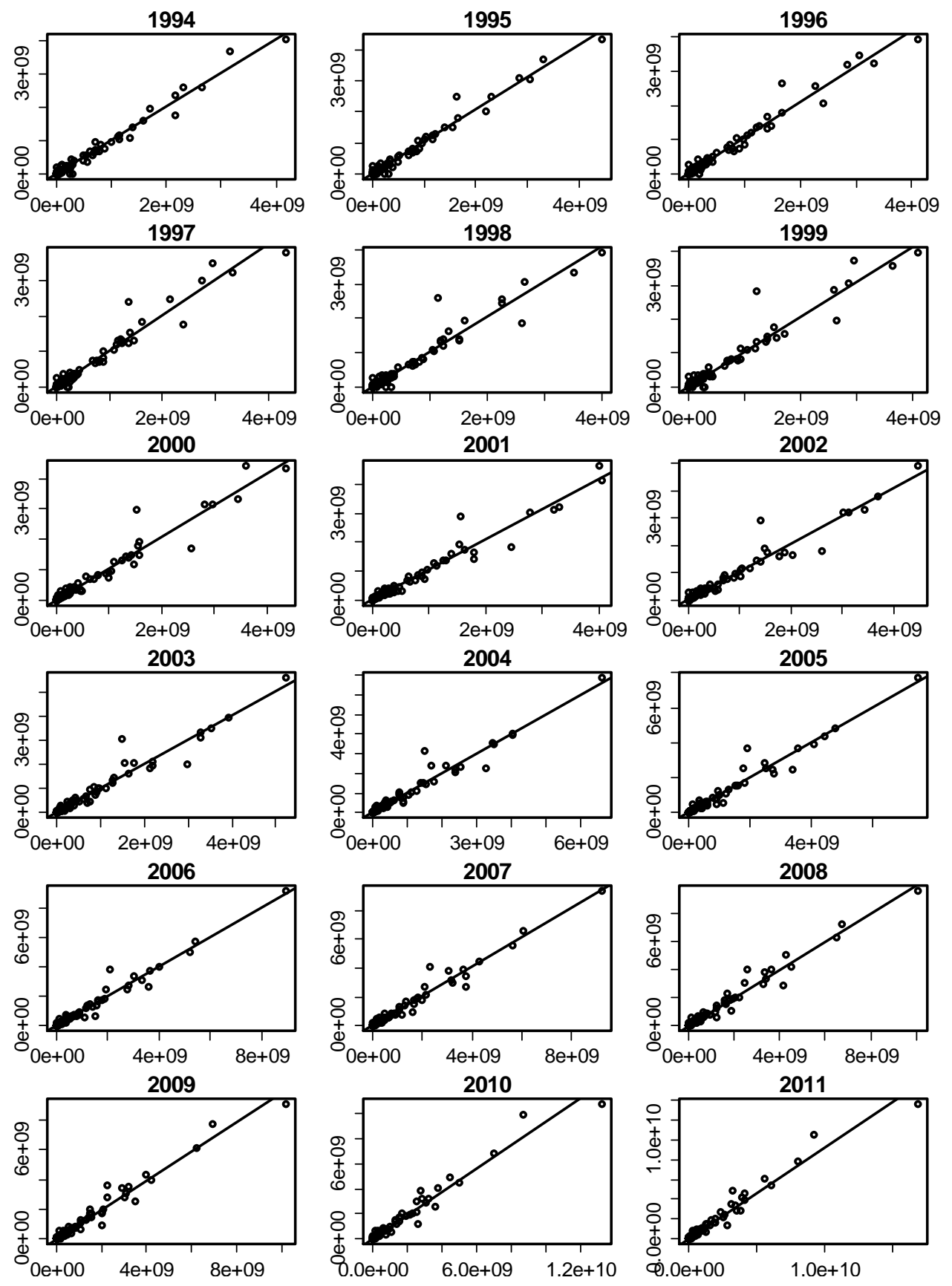

Supplementary Figure 2: Scatterplots with regression lines comparing the FishStat total export data to each country's total exports (USD) in Comtrade (summed across exports from each importer). Regression coefficients and $\mathrm{r}^{2}$ values are presented in Supplementary Table 1. Plots for quantity data are similar and regression coefficients and $r^{2}$ values for quantity data are also presented in Supplementary Table 1. 


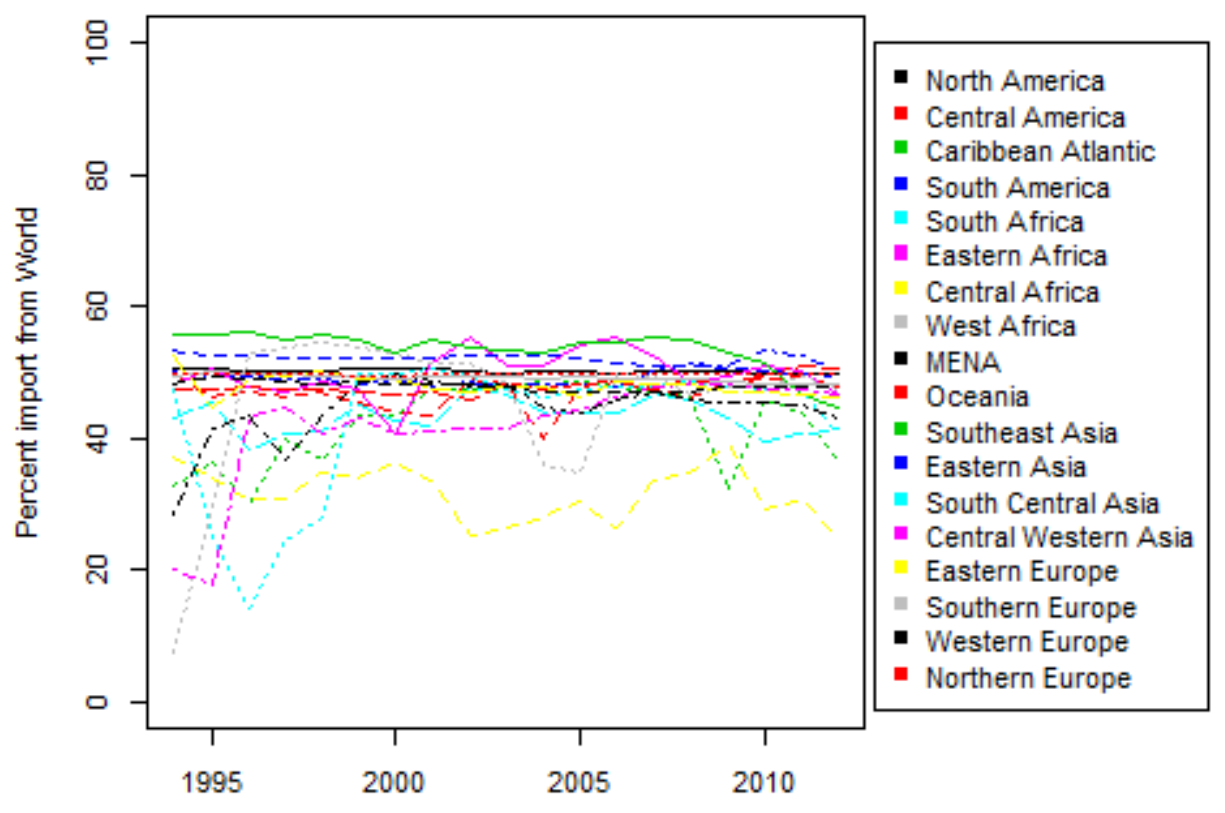

Supplementary Figure 3: Percent of imports by each region attributed to the category "World." Since the percent from "World" remains relatively constant over the time period considered and trade from "World" contains no information about the product origin, this category was excluded from the analysis unless otherwise noted. Further justification for excluding "World" is provided in the methods and Supporting Information section. 

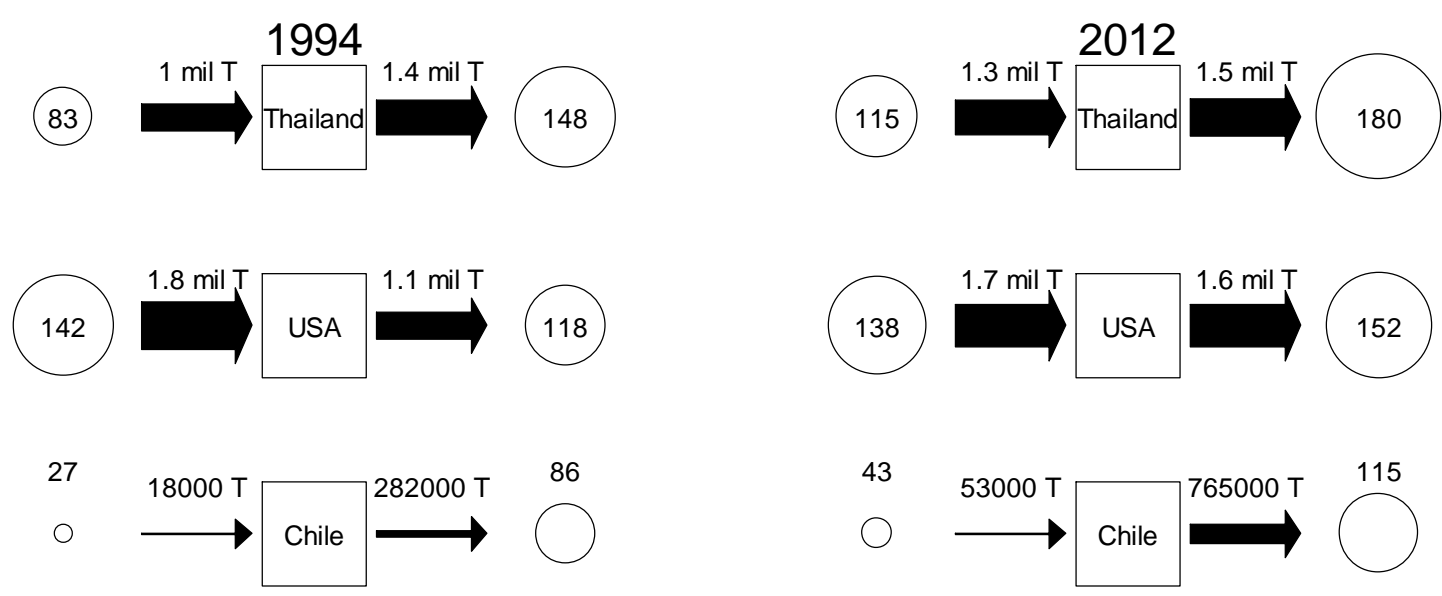

Supplementary Figure 4: Alternative version of Figure 1.1 using quantity (tonnes) of imports and exports. Example shows changes in the number of exporters (in degree), import flow, importers (out degree), and export flow for Thailand, USA, and Chile. Number of exporters and importers are indicated by the area of the circle and import/export flow (in tonnes) is indicated by the arrow width. 


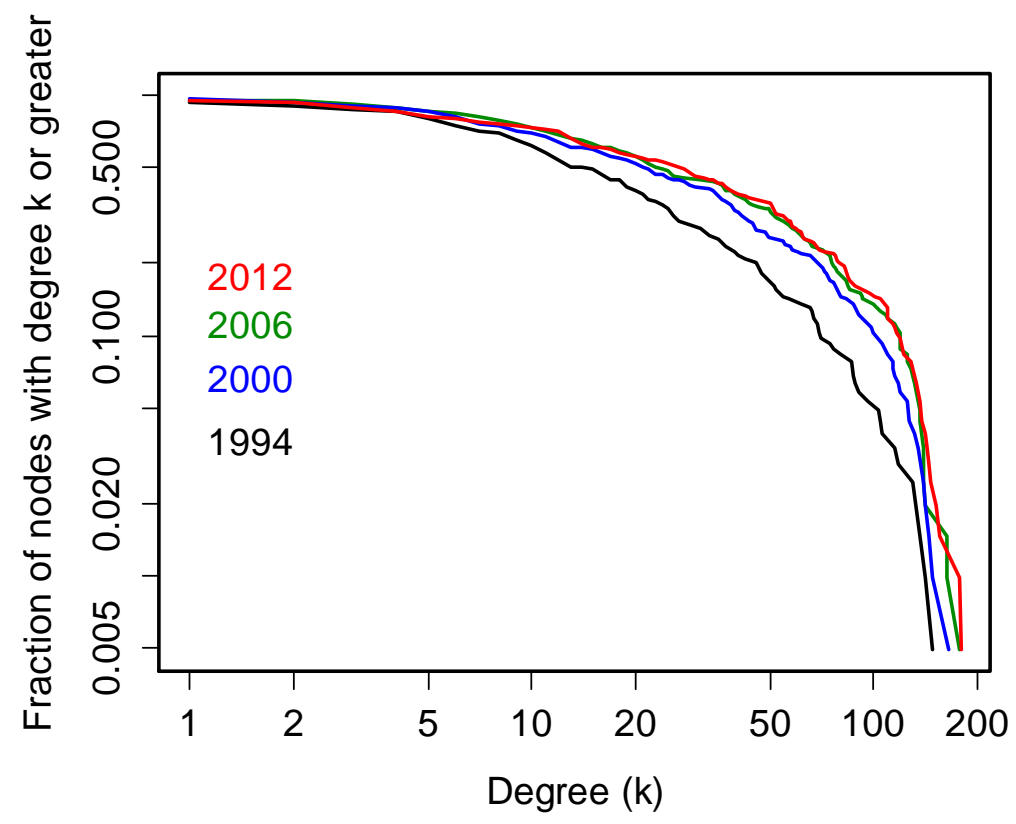

Supplementary Figure 5: Cumulative distribution of nodes with degree (k) or higher for four years throughout the study period. 


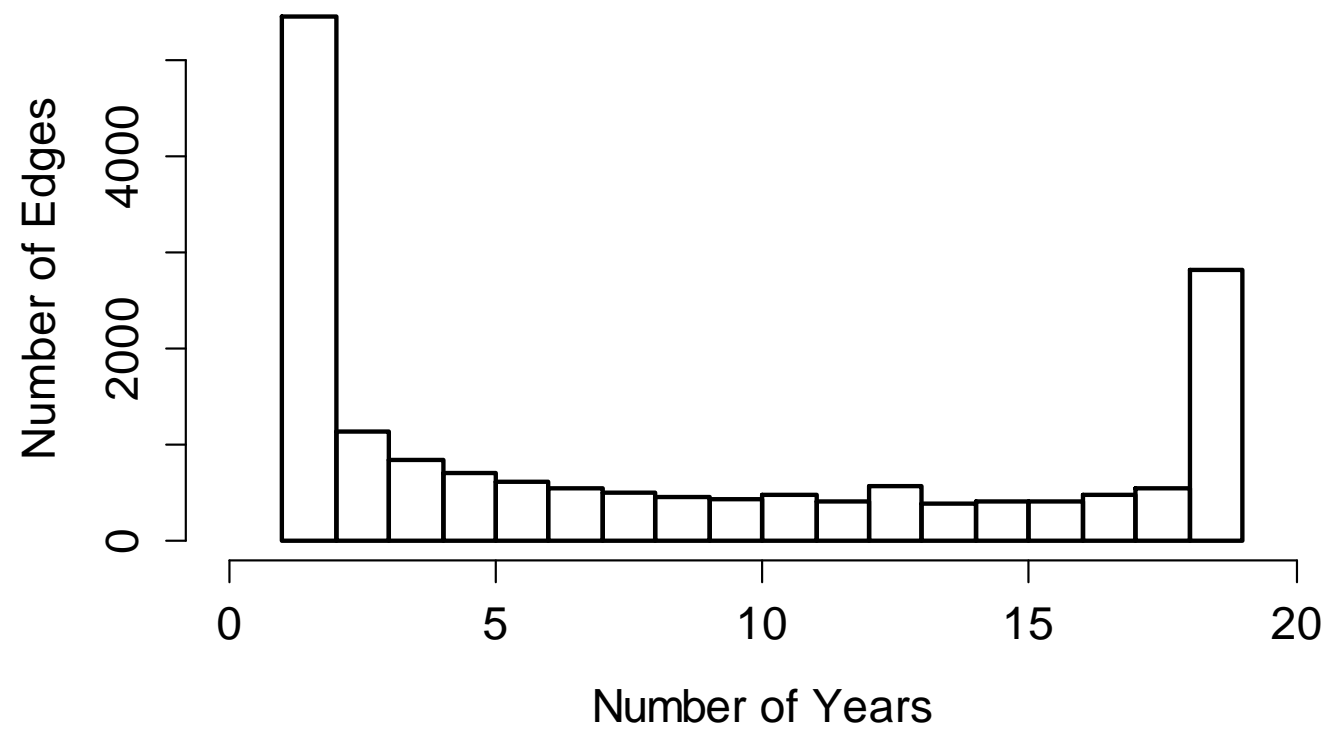

Supplementary Figure 6: A histogram of the number of edges (trade partnerships) that exist for a given number of years in the network. The network is dominated by trade partnerships that last a single year. 


\section{APPENDIX 2: CHAPTER 2 SUPPLEMENTARY MATERIAL}

\section{Methods}

Derivation of closed formula for the exposure of each node

Assuming that shocks are passed on in proportion to the original trade flows and that shocks are sufficiently small so that the shock can always be passed on, it follows that the equilibrium result can be computed using the following linear equations. To see this, assume that of a shock (1-q)e is absorbed locally and Tqe is transferred, where $\mathrm{q}$ is the proportion of the shock passed on, $\mathrm{e}$ is the exports from each region, and $\mathrm{T}$ is the transfer matrix, consisting of the proportion of exports from each region being exported to each other region. At the next iteration, (1-q)Tqe is absorbed and $\mathrm{Tq}(\mathrm{Tqe})$ is transferred, and so on. The impact of the shock (c, change in consumption) on each node is then the sum of the absorbed shock at each node:

$c=(1-q) e+(1-q) T q e+(1-q) T^{\wedge} 2 q^{\wedge} 2$ e $+\cdots$.

This is a geometric series which converges for $0 \leq \mathrm{q}<1$ as the eigenvalues of $\mathrm{qT}$ all have magnitude less than one. Thus, the impact at equilibrium is $c=(1-q) B e$, where $B=[I-T q]^{\wedge}(-1)$.

\section{Robustness of uniform q assumption}

The model presented in this paper assumes a uniform value for the propensity to pass on shocks, i.e., that parameter $\mathrm{q}$ among the regions. Here, we assess the robustness of this assumption by allowing $q$ to vary among the regions. To investigate the impact of varying $q$ by region on the model results, we independently draw a value for $\mathrm{q}$ from a beta distribution (shape parameters 2 , 2), which provides high variability among q values between 0 and 1 for each region (coefficient of variation of 0.45 for $q)$. All other parameters are held constant $(\alpha=0$ and $s=0.5)$ to explore the 
variation due to allowing different $\mathrm{q}$ values for each region. We ran the model 10,000 times and plotted the mean and coefficient of variation for the percent of shock in each region due to a shock initiated in each other region (Appendix 2, Supplementary Figure 4b and 5). Our predictions of average shocks (Appendix 2, Supplementary Figure 5a) show a very similar pattern to when q is held constant for all countries (Appendix 2, Supplementary Figure 5b) even with high variability in q. The difference between the average results when q varies by country versus when it is held constant for all countries were small, all less than 0.6 percent. Allowing different q values by region does produce variability in these results depending on how the selection of $\mathrm{q}$ for each region and the variability is approximately on the scale of the variability in the choice of q (Appendix 2, Supplementary Figure 4b). This demonstrates that our average predictions and general patterns we highlight in this manuscript are unaffected by the assumption of a fixed $\mathrm{q}$, but that empirical estimates of q are necessary to model specific scenarios. 


\section{Additional Tables and Figures}

Supplementary Table 1: Table provides grouping of countries into the regions used in this analysis. Country names area associated with all country codes that appear within the Comtrade dataset, but do not all necessarily engage in trade in 2011. NES indicates that the trade occurred within that region, with an entity not elsewhere specified. Regional categorization was based on the One World Nations Online regional designations (One World Nations Online 2014).

\begin{tabular}{|c|c|c|}
\hline Region & \multicolumn{2}{|c|}{ Country } \\
\hline \multicolumn{3}{|c|}{ Caribbean \& Atlantic Islands } \\
\hline Antigua and Barbuda & Dominica & Netherlands Antilles \\
\hline Aruba & Dominican Republic & Saint Helena \\
\hline Bahamas & Grenada & $\begin{array}{l}\text { Saint Kitts, Nevis and } \\
\text { Anguilla }\end{array}$ \\
\hline Barbados & Guadeloupe & Saint Lucia \\
\hline Bermuda & Haiti & $\begin{array}{l}\text { Saint Vincent and the } \\
\text { Grenadines }\end{array}$ \\
\hline Cayman Islands & Jamaica & Trinidad and Tobago \\
\hline Cuba & Martinique & Turks and Caicos Islands \\
\hline Curaçao & & \\
\hline \multicolumn{3}{|c|}{ Central Africa } \\
\hline Angola & Chad & Equatorial Guinea \\
\hline Cameroon & Congo & Gabon \\
\hline Central African Republic & $\begin{array}{l}\text { Democratic Republic of the } \\
\text { Congo }\end{array}$ & Sao Tome and Principe \\
\hline \multicolumn{3}{|c|}{ Central America } \\
\hline Belize & Guatemala & Nicaragua \\
\hline Costa Rica & Honduras & Panama \\
\hline El Salvador & & \\
\hline \multicolumn{3}{|c|}{ Central and Western Asia } \\
\hline Armenia & Kazakhstan & Turkey \\
\hline Azerbaijan & Kyrgyzstan & Turkmenistan \\
\hline Cyprus & Mongolia & Uzbekistan \\
\hline Georgia & Russian Federation & \\
\hline \multicolumn{3}{|c|}{ Eastern Africa } \\
\hline Burundi & Malawi & Seychelles \\
\hline Comoros & Mauritius & Somalia \\
\hline Djibouti & Mayotte & Uganda \\
\hline Ethiopia and Eritrea & Mozambique & $\begin{array}{l}\text { United Republic of } \\
\text { Tanzania }\end{array}$ \\
\hline Kenya & Réunion & Zambia \\
\hline Madagascar & Rwanda & \\
\hline
\end{tabular}




\begin{tabular}{|c|c|c|}
\hline $\begin{array}{l}\text { China } \\
\text { China, Hong Kong SAR }\end{array}$ & $\begin{array}{l}\quad \text { Eastern Asia } \\
\text { China, Macao SAR } \\
\text { Democratic People's } \\
\text { Republic of Korea }\end{array}$ & $\begin{array}{l}\text { Japan } \\
\text { Republic of Korea }\end{array}$ \\
\hline \multicolumn{3}{|c|}{ Eastern Europe } \\
\hline Belarus & Hungary & Romania \\
\hline Bulgaria & Poland & Slovakia \\
\hline Czech Republic & Republic of Moldova & Ukraine \\
\hline \multicolumn{3}{|c|}{ Middle East and Northern Africa (MENA) } \\
\hline Algeria & Lebanon & Saudi Arabia \\
\hline Bahrain & Libya & Sudan \\
\hline Egypt & Morocco & Syria \\
\hline Iraq & $\begin{array}{l}\text { Occupied Palestinian } \\
\text { Territory }\end{array}$ & Tunisia \\
\hline Israel & Oman & United Arab Emirates \\
\hline $\begin{array}{l}\text { Jordan } \\
\text { Kuwait }\end{array}$ & Qatar & Yemen \\
\hline \multicolumn{3}{|c|}{ North America } \\
\hline Canada & Mexico & USA \\
\hline Greenland & Saint Pierre and Miquelon & \\
\hline \multicolumn{3}{|c|}{ Northern Europe } \\
\hline Denmark & Iceland & Norway \\
\hline Estonia & Ireland & Sweden \\
\hline Faeroe Islands & Latvia & United Kingdom \\
\hline Finland & Lithuania & \\
\hline \multicolumn{3}{|c|}{ Oceania } \\
\hline Australia & Kiribati & Samoa \\
\hline Cook Islands & Marshall Islands & Solomon Islands \\
\hline Fiji & New Caledonia & Tonga \\
\hline French Polynesia & New Zealand & Tuvalu \\
\hline $\begin{array}{l}\text { FS Micronesia } \\
\text { Guam }\end{array}$ & Palau & Vanuatu \\
\hline \multicolumn{3}{|c|}{ South America } \\
\hline Argentina & Ecuador & Peru \\
\hline Bolivia & Falkland Islands & Suriname \\
\hline Brazil & French Guiana & Uruguay \\
\hline Chile & Guyana & Venezuela \\
\hline Colombia & Paraguay & \\
\hline \multicolumn{3}{|c|}{ South-Central Asia } \\
\hline Bangladesh & Iran & Pakistan \\
\hline Bhutan & Maldives & Sri Lanka \\
\hline India & Nepal & \\
\hline \multicolumn{3}{|c|}{ Southeast Asia } \\
\hline Brunei Darussalam & Malaysia & Singapore \\
\hline Cambodia & Myanmar & Thailand \\
\hline
\end{tabular}




\begin{tabular}{|lll|}
$\begin{array}{l}\text { Indonesia } \\
\text { Lao People's Democratic } \\
\text { Republic }\end{array}$ & $\begin{array}{l}\text { Papua New Guinea } \\
\text { Philippines }\end{array}$ & $\begin{array}{l}\text { Timor-Leste } \\
\text { Viet Nam }\end{array}$ \\
\hline $\begin{array}{l}\text { Botswana } \\
\text { Lesotho }\end{array}$ & $\begin{array}{l}\text { Southern Africa } \\
\text { Namibia } \\
\text { South Africa }\end{array}$ & $\begin{array}{l}\text { Swaziland } \\
\text { Zimbabwe }\end{array}$ \\
\hline $\begin{array}{l}\text { Albania } \\
\text { Bosnia Herzegovina }\end{array}$ & Southern Europe & \\
$\begin{array}{l}\text { Croatia } \\
\text { Greece }\end{array}$ & Malta & $\begin{array}{l}\text { Slovenia } \\
\text { Spain }\end{array}$ \\
\hline $\begin{array}{l}\text { Benin } \\
\text { Burkina Faso }\end{array}$ & Portugal & TFYR of Macedonia \\
Cape Verde & Serbia and Montenegro & \\
Côte d'Ivoire & Guinea & Niger Africa \\
Gambia & Guinea-Bissau & Nigeria \\
Ghana & Liberia & Senegal \\
\hline & Mali & Sierra Leone \\
Austria & Mauritania & Togo \\
Belgium-Luxembourg & Germany & Netherlands \\
\hline
\end{tabular}




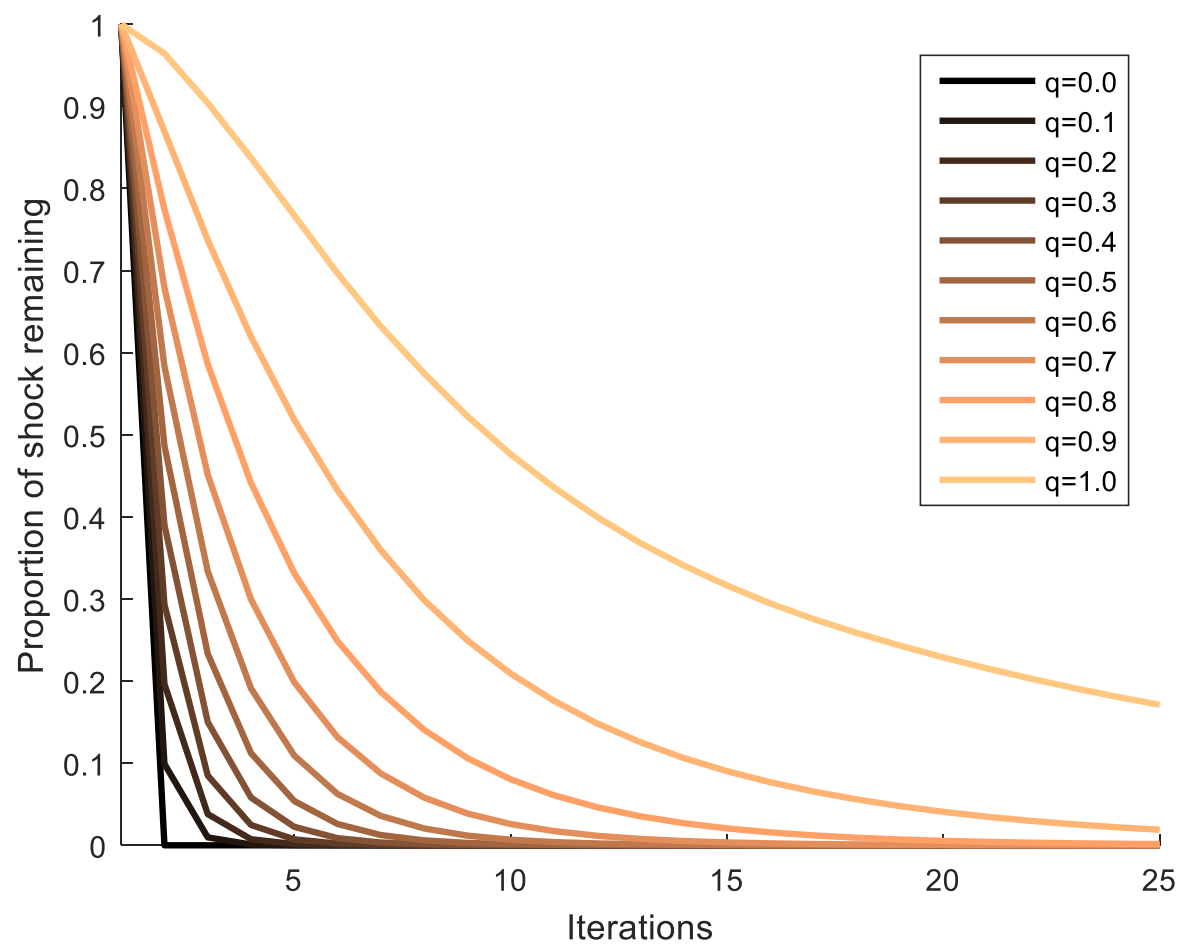

Supplementary Figure 1: Percent of shock remaining at each iteration number for varying degrees of spread (q). 

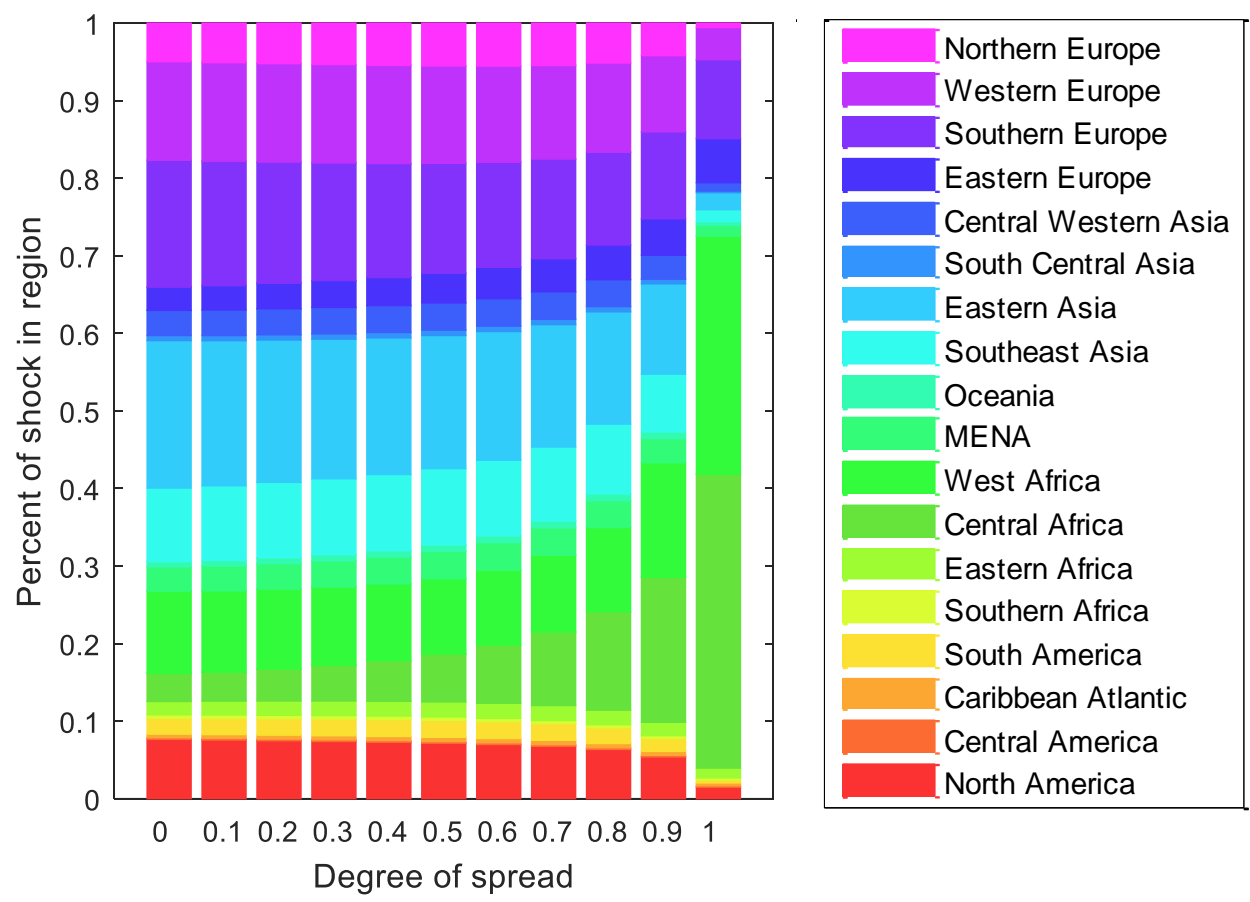

Degree of spread

Supplementary Figure 2: Increasing the degree of spread increases the proportion of the shock ending up in West Africa and Central Africa. Stacked bars show the average (over degree of shock and perturbed region) percent of shock ending up in each region for varying degrees of spread. Increasing the degree of spread increases the percent of the shock ending up in West and Central Africa, while decreasing or having little effect on the percent of shock ending up in the other regions. 


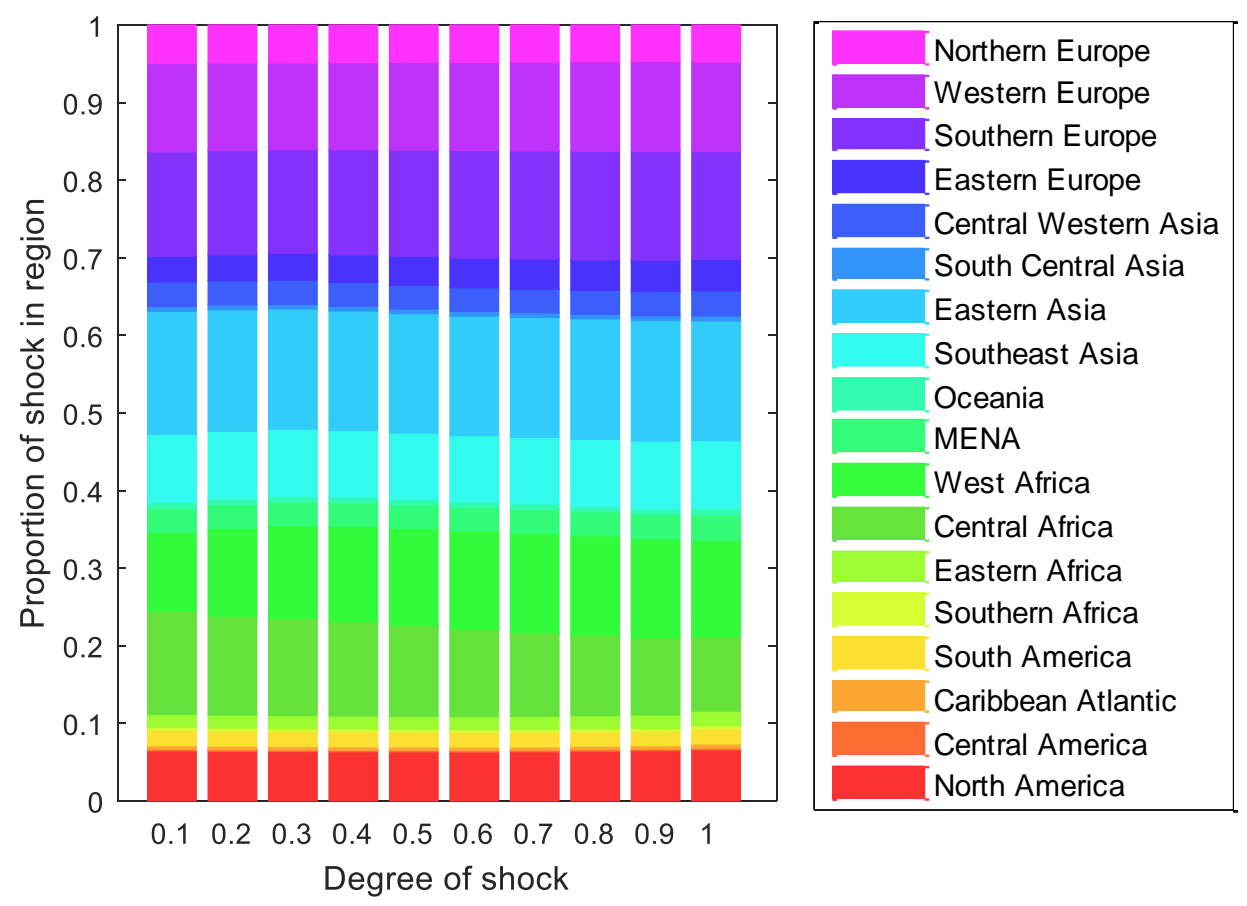

Supplementary Figure 3: The proportion of the shock ending up in each region is insensitive to the size of the initial shock. Average percent of the shock ending up in each region for varying degrees of shock. The similar shock distribution across the different degrees of shock suggests that the results are fairly robust to the size of the shock. 


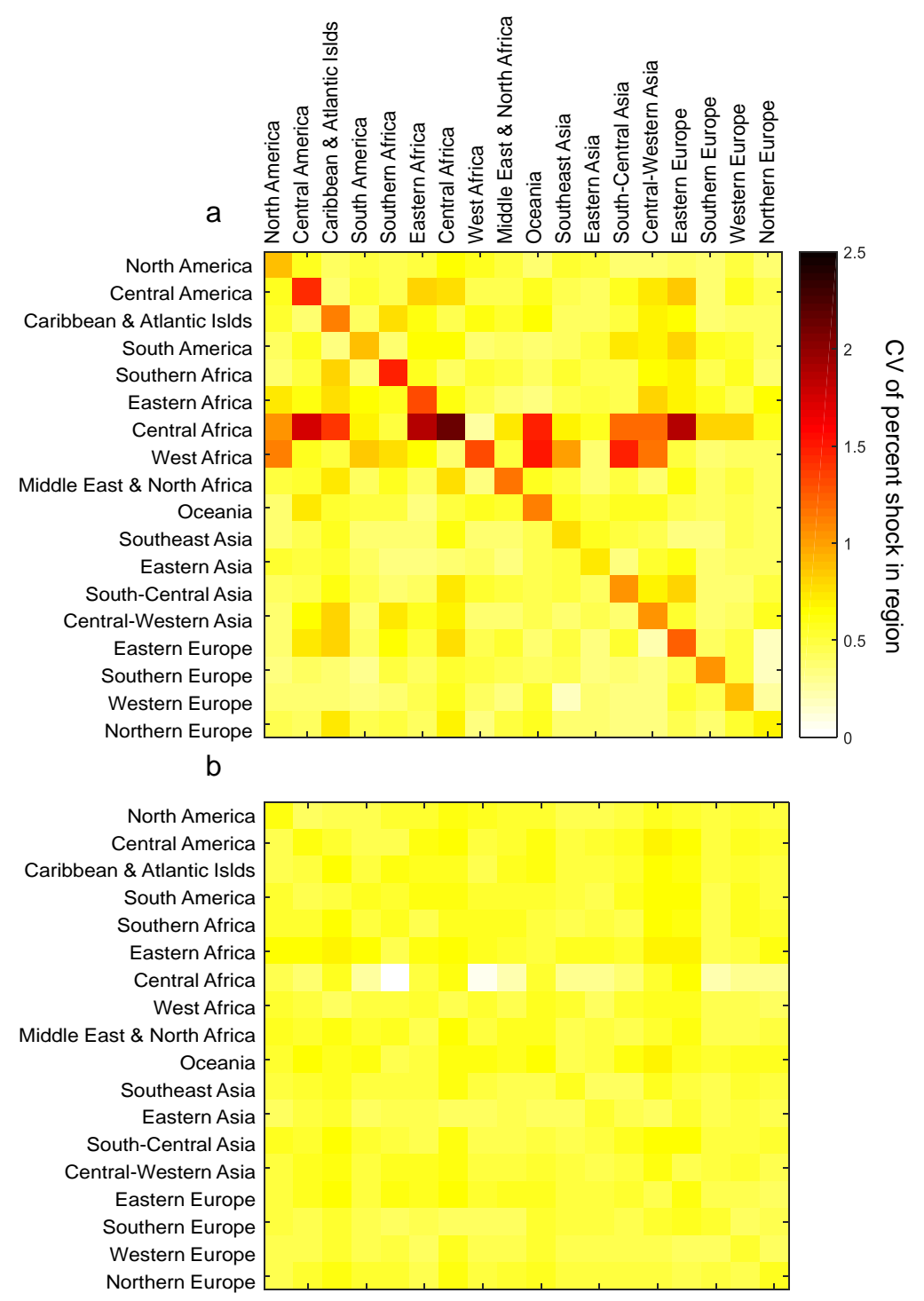

Supplementary Figure 4: a) Variation in the exposure to shocks initiated in each region. The coefficient of variation (CV) for each region's (vertical axis) exposure to a perturbation occurring in each other region (horizontal axis) is indicated by cell color, representing the CV percent of initial shock ending up in each region across degree of shock and degree of spread (with no GDP effect included). b) Coefficient of variation for the percent of shock in each importing region (row) due to a shock initiated in each other region (column) for repeated model runs where $q$ is allowed to vary from region to region but all other parameters are held constant ( $\alpha=0$ and $s=0.5$ ). 


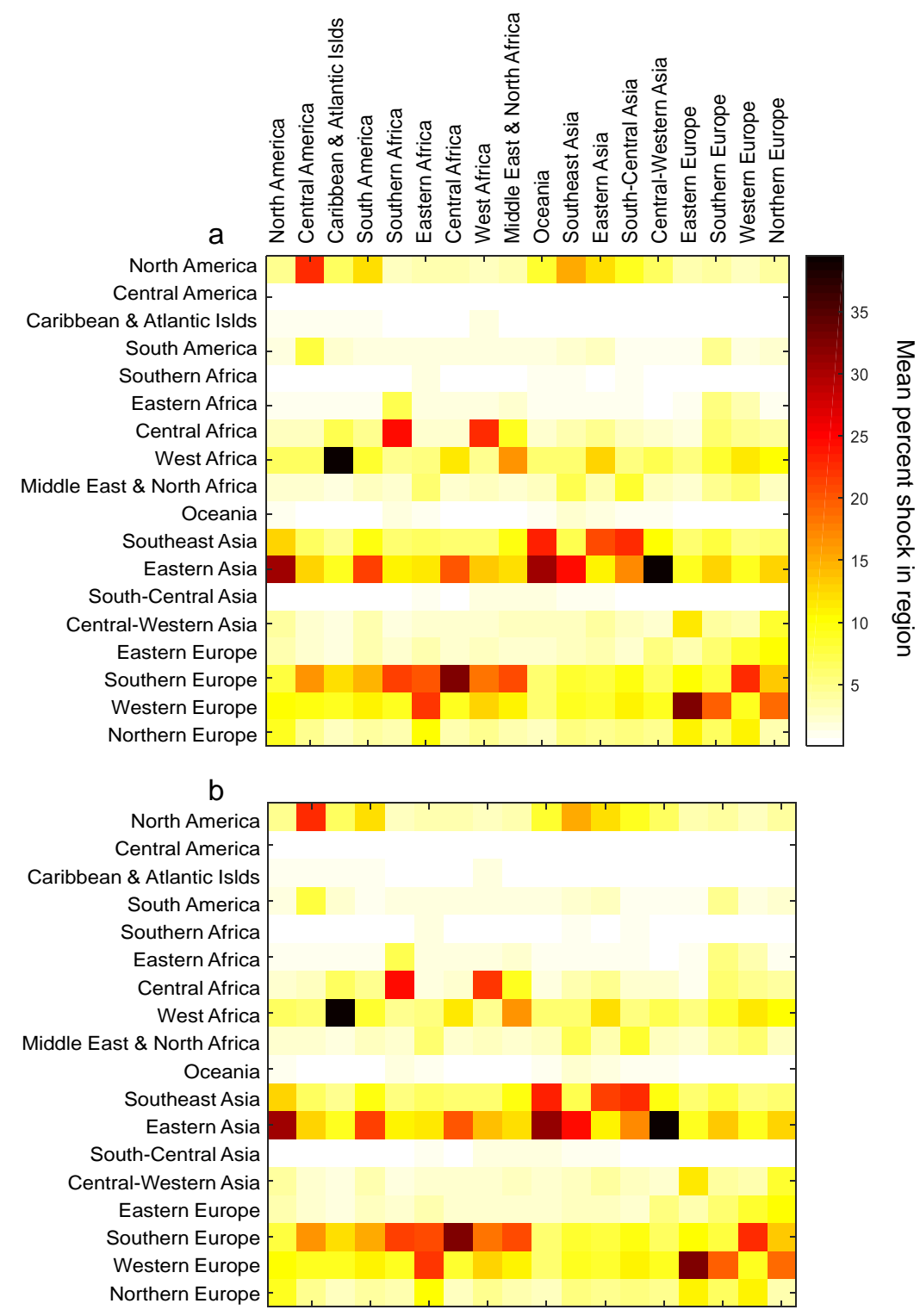

Supplementary Figure 5: Average percent of shock in each importing region (row) due to a shock initiated in each other region (column) for a) repeated model runs where $q$ is allowed to vary from region to region but all other parameters are held constant ( $\alpha=0$ and $s=0.5$ ), and $\mathrm{b}$ ) a model run with $q=0.5$ for all regions. 


\section{APPENDIX 3: CHAPTER 3 SUPPLEMENTARY MATERIAL}

\section{Detection Sensitivity}

The sensitivity of the shock detection method used in this study depends on both the variability of a time series and the magnitude of the shock being identified. Time series were simulated with varying shock magnitudes and different levels of random variation in order to test the proportion of shocks detected for each combination (Supplementary Table 1). Time series were modelled using an ARIMA model with an AR term of - 0.1 and one degree of differencing. The model order and AR term were determined by selecting the most common parameters after fitting ARIMA models to each seafood production time series using auto.arima function from the forecast package and the arima function in R. Each combination of standard deviation (ranging from 0 to 1 ) and shock magnitude (ranging 0 to 6) was simulated 1000 times. The shock detection approach described in the methods was then applied to each time series to calculate the proportion of times the imposed shock was detected. The detection method had a very low false positive rate, with essentially no shocks being detected when no shock was imposed (magnitude equal to zero). The ability to detect a shock decreases as standard deviation of the time series increases and increases as the shock magnitude increases. Consequently, the ratio of the shock magnitude to the standard deviation determines the ability to reliably detect a shock. The ratio of shock magnitude to time series standard deviation for the shocks detected in the seafood production data ranged from 0.03 to 6 , with most values falling around 2 . 
Supplementary Table 1: Proportion of imposed shocks that were detected for different degrees of variability (standard deviation varies across columns) and shock magnitude (degree of shock varies down rows).

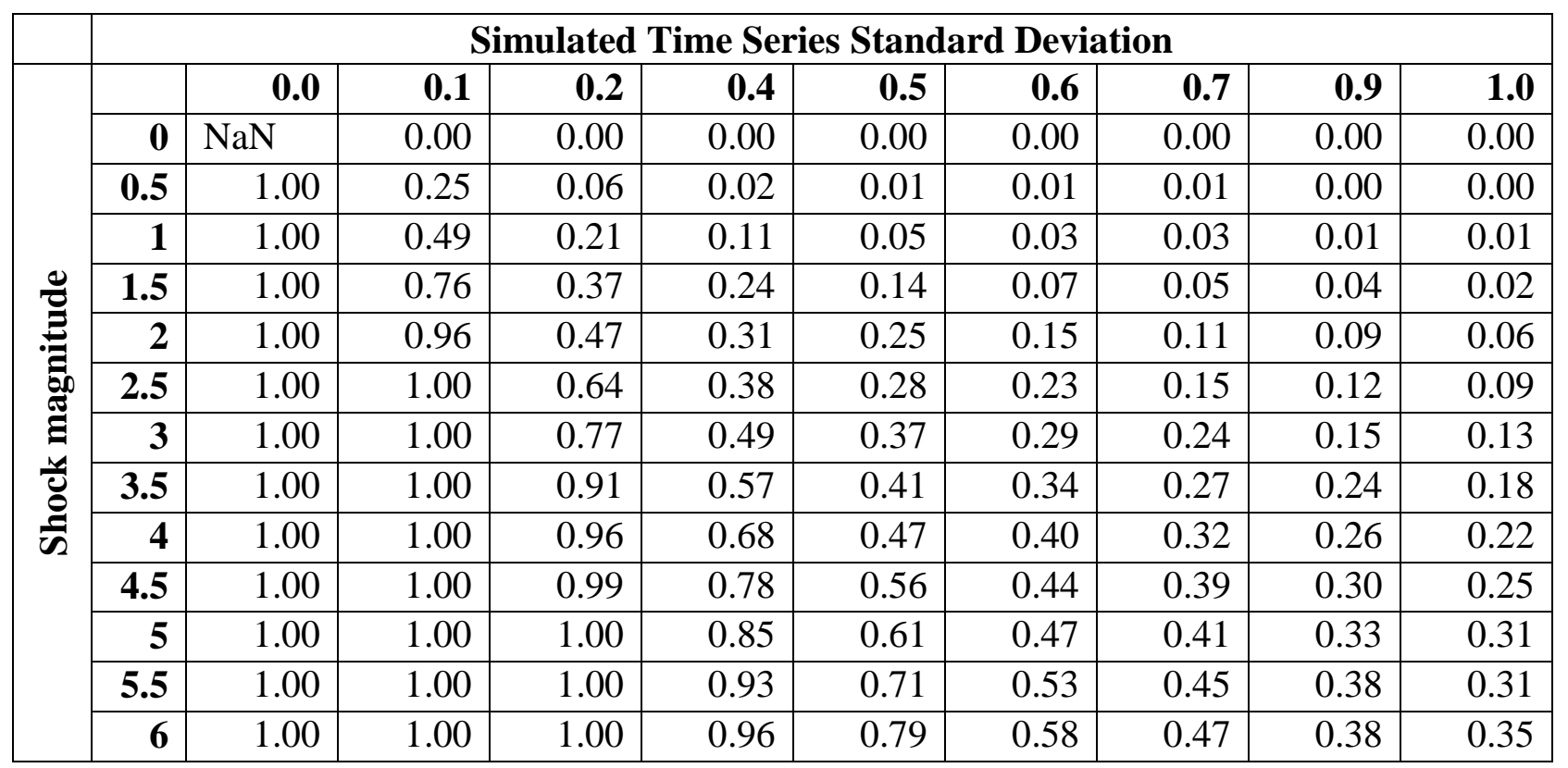

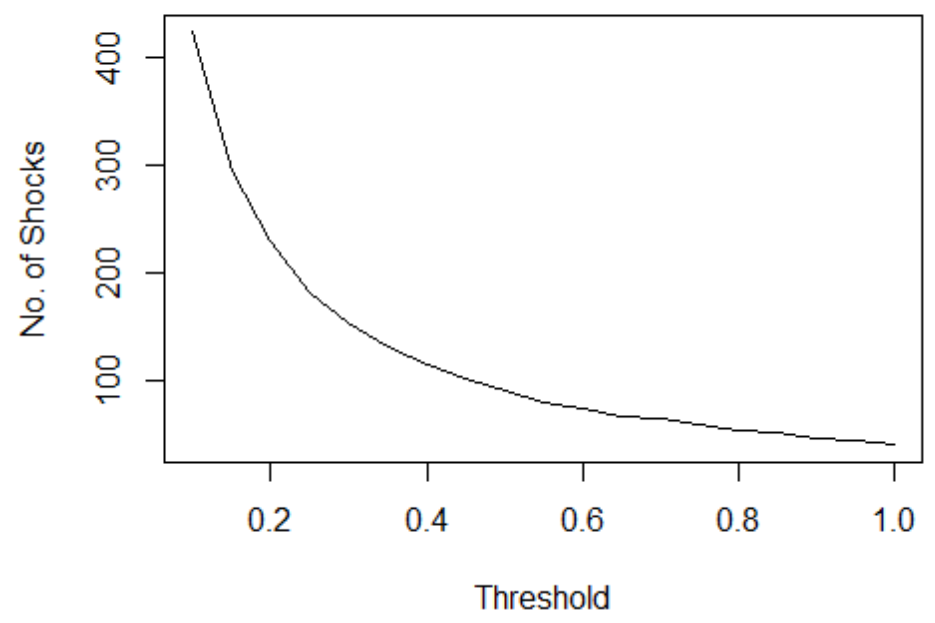

Supplementary Figure 1: Number of shocks identified versus threshold set for the Cook's D value. 


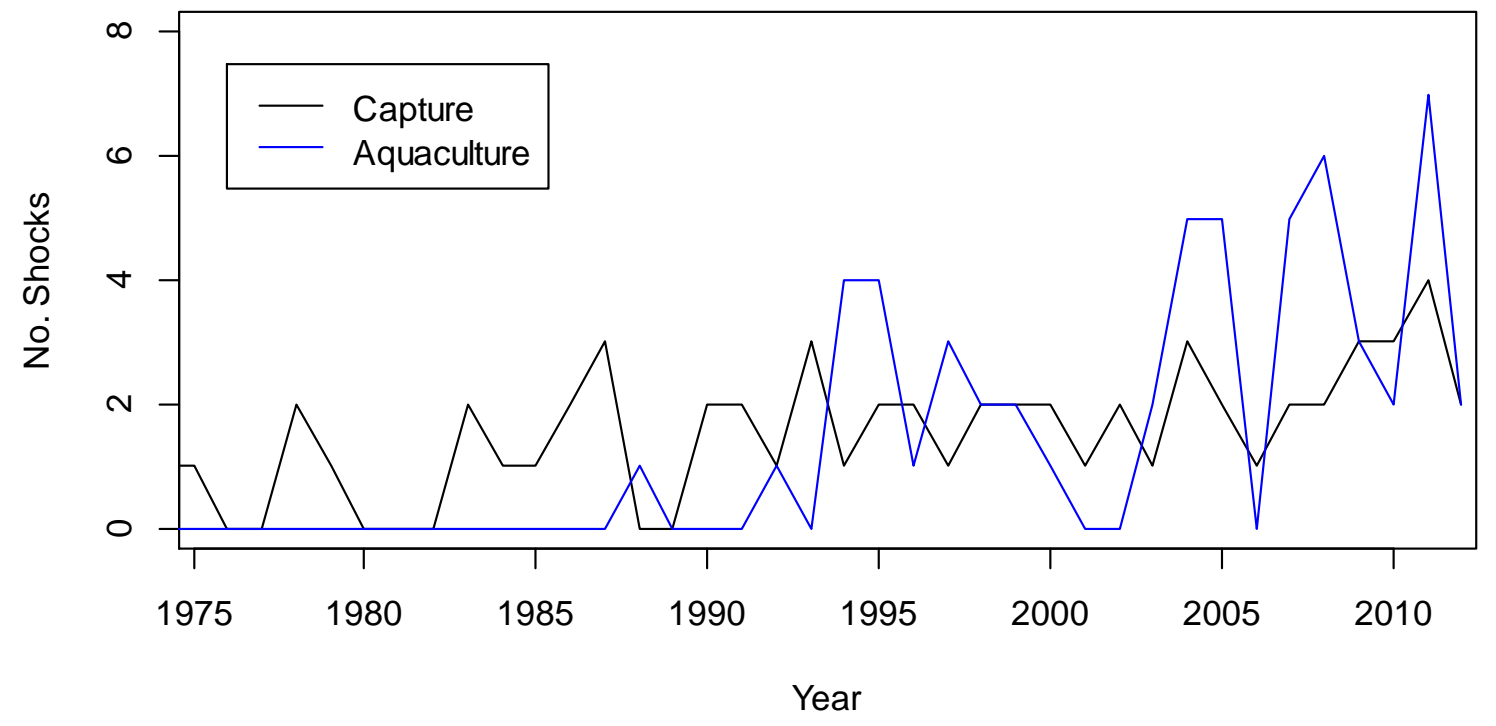

Supplementary Figure 2: Total number of shocks in capture fishery (black) and aquaculture (blue) production time series for each country. 


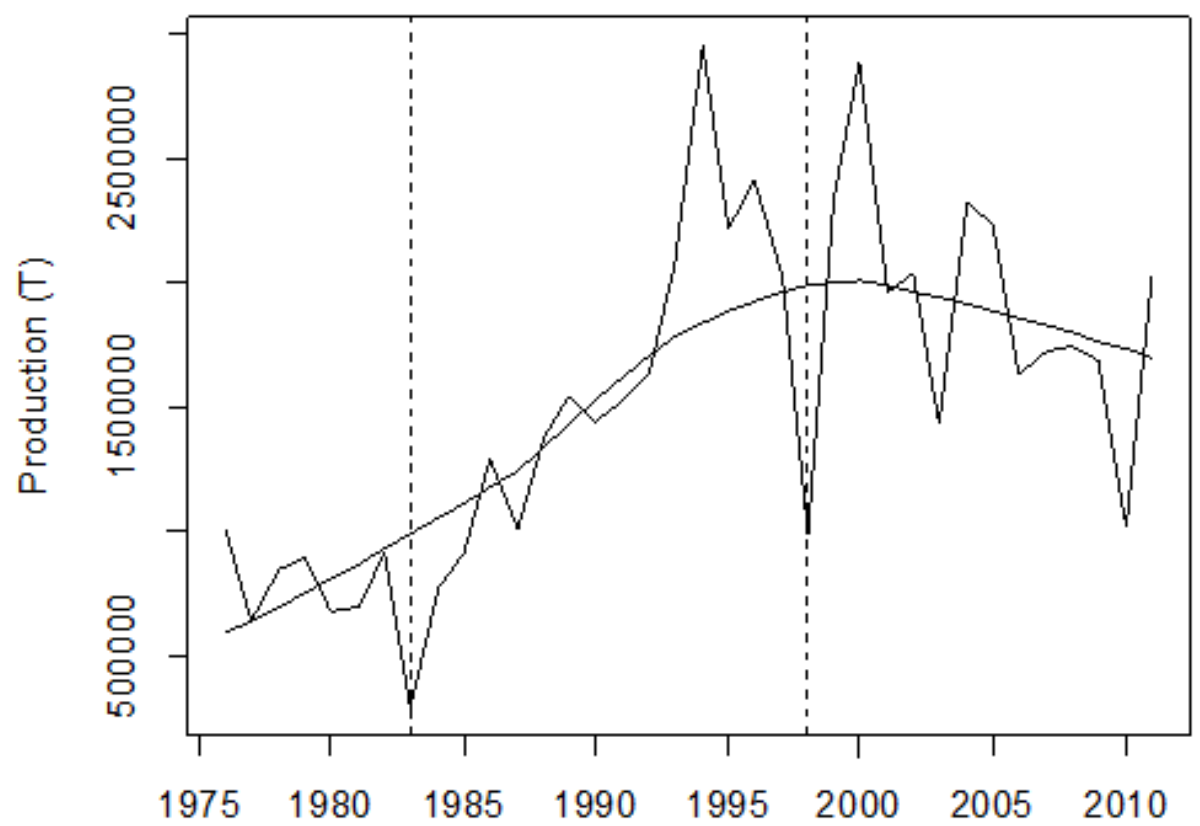

Supplementary Figure 3: Peruvian herring, anchovy and sardine catch time series. Despite the visual drop in catch during the 1982-1983 and 1997-1998 El Niño events (indicated with vertical dashed lines), the Cook's D values (0.02 and 0.19$)$ are less than the threshold of 0.35 , which can be attributed to the relatively high variability in the catch. 